Report of Investigation 2018-6

\title{
GEOLOGIC MAP OF THE UMIAT-GUBIK AREA, CENTRAL NORTH SLOPE, ALASKA
}

Trystan M. Herriott, Marwan A. Wartes, Paul L. Decker, Robert J. Gillis, Diane P. Shellenbaum, Amanda L. Willingham, and David J. Mauel

Cover. Outcrop of the Nanushuk Formation along the Colville River's north bank at the informally named Colville incision locality. Sandstones of the Nanushuk serve as reservoirs at the Umiat oil field $20 \mathrm{~km}$ to the northeast. Hammer is $31 \mathrm{~cm}$ long. Photograph by T.M. Herriott. 


\section{GEOLOGIC MAP OF THE UMIAT-GUBIK AREA, CENTRAL NORTH SLOPE, ALASKA}

Trystan M. Herriott, Marwan A. Wartes, Paul L. Decker,

Robert J. Gillis, Diane P. Shellenbaum, Amanda L. Willingham, and David J. Mauel

Report of Investigation 2018-6

State of Alaska

Department of Natural Resources

Division of Geological \& Geophysical Surveys 


\section{STATE OF ALASKA}

Bill Walker, Governor

DEPARTMENT OF NATURAL RESOURCES

Andrew T. Mack, Commissioner

DIVISION OF GEOLOGICAL \& GEOPHYSICAL SURVEYS

Steve Masterman, State Geologist and Director

Publications produced by the Division of Geological \& Geophysical Surveys (DGGS) are available for free download from the DGGS website (dggs.alaska.gov). Publications on hard-copy or digital media can be examined or purchased in the Fairbanks office:

Alaska Division of Geological \& Geophysical Surveys 3354 College Rd., Fairbanks, Alaska 99709-3707

Phone: (907) 451-5010 Fax (907) 451-5050

dggspubs@alaska.gov | dggs.alaska.gov

DGGS publications are also available at:

Alaska State Library,

Historical Collections \& Talking Book Center

395 Whittier Street

Juneau, Alaska 99811

Alaska Resource Library and Information Services (ARLIS)

3150 C Street, Suite 100

Anchorage, Alaska 99503

Suggested citation:

Herriott, T.M., Wartes, M.A., Decker, P.L., Gillis, R.J., Shellenbaum, D.P., Willingham, A.L., and Maueul, D.J., 2018, Geologic map of the Umiat-Gubik area, central North Slope, Alaska: Alaska Division of Geological \& Geophysical Surveys Report of Investigation 2018-6, 55 p., 1 sheet, scale 1:63,360.

http://doi.org/10.14509/30099
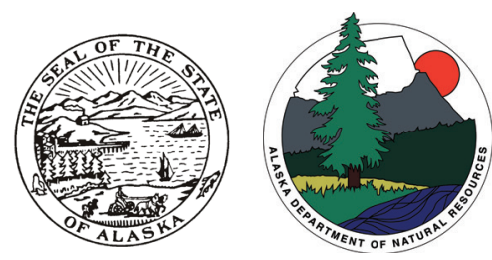



\section{Contents}

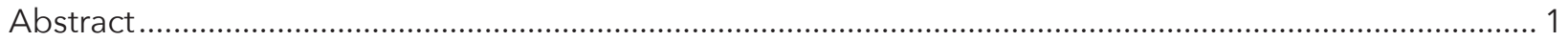

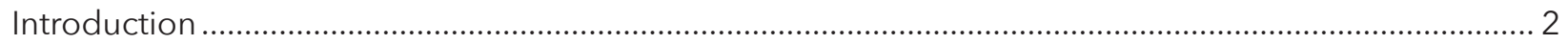

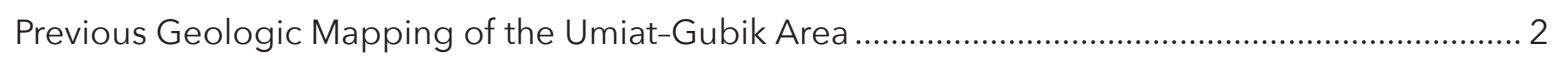

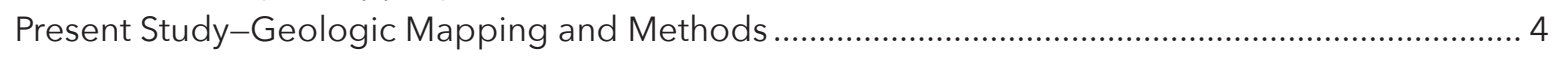

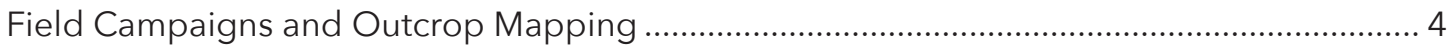

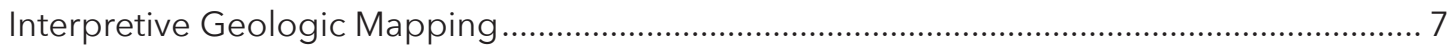

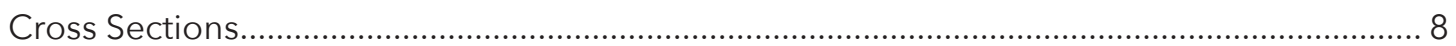

Overview of Petroleum Geology in the Umiat-Gubik and Surrounding Areas.................................. 8

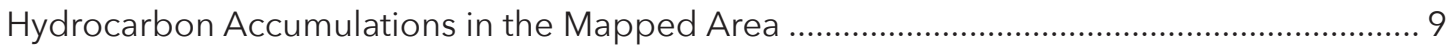

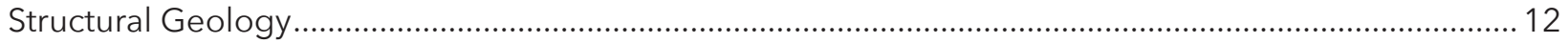

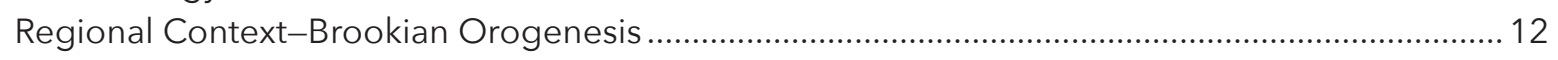

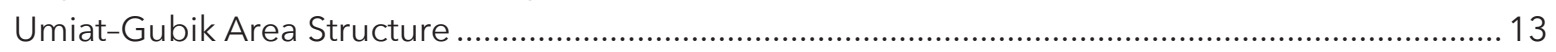

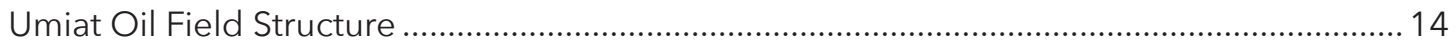

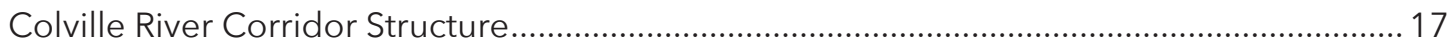

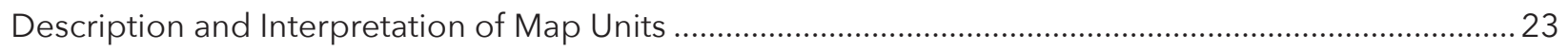

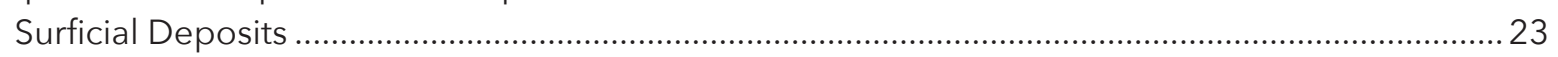

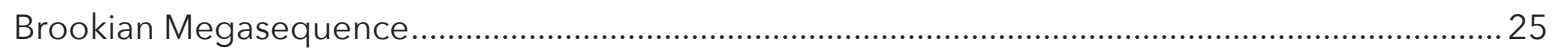

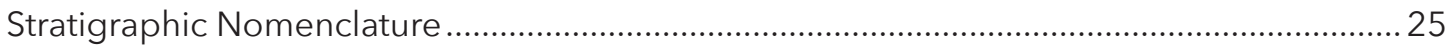

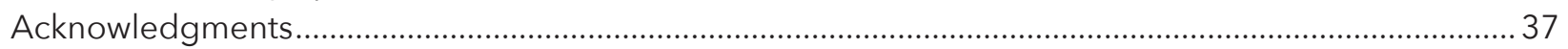

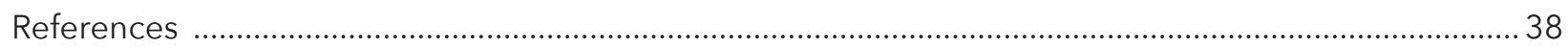

\section{Figures}

Figure 1. Location map of the Umiat-Gubik area ................................................................................ 3

Figure 2. Schematic cross section of the Brooks Range and North Slope ................................................ 4

Figure 3. Photographs exhibiting typical terrain and locally excellent outcrop character of

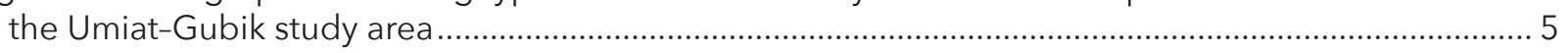

Figure 4. Colville foreland basin chronostratigraphic column ................................................................. 6

Figure 5. Depth structure map of Umiat-Gubik map area................................................................... 9

Figure 6. Oblique aerial photographs of gentle, $\mathrm{km}$-scale wavelength folds that are typical of

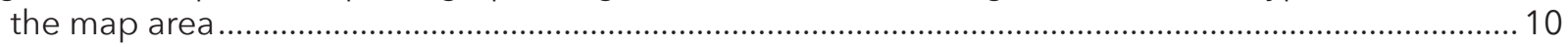

Figure 7. Interferometric synthetic aperture radar (IFSAR)-based shaded-relief map of Umiat

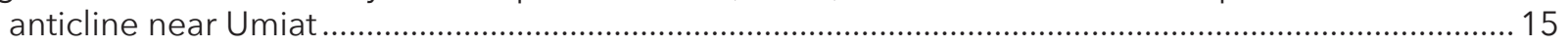

Figure 8. Idealized strain ellipse for left-lateral strike-slip fault system in simple shear.......................... 18

Figure 9. Equal area stereonet plots of all Colville River fracture data and plots of fractures

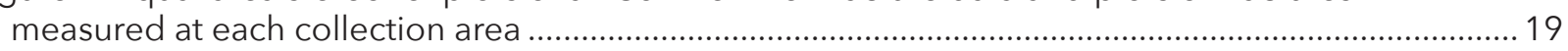

Figure 10. Equal area stereonet plots of Colville River fractures ........................................................... 20

Figure 11. Axial trace line drawings for folds in the Umiat-Gubik map area...........................................23

Figure 12. Stereonet plots of fracture data interpreted within a pure shear deformation model............24

Figure 13. Field photographs of Prince Creek Formation ........................................................................2

Figure 14. Field photographs of Sentinel Hill Member, Schrader Bluff Formation .................................. 29

Figure 15. Field photographs of Barrow Trail Member, Schrader Bluff Formation ..................................30

Figure 16. Field photographs of Rogers Creek Member, Schrader Bluff Formation .................................31

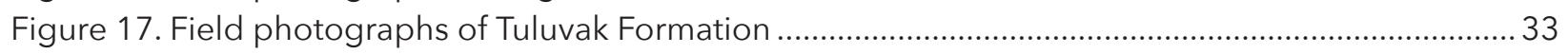

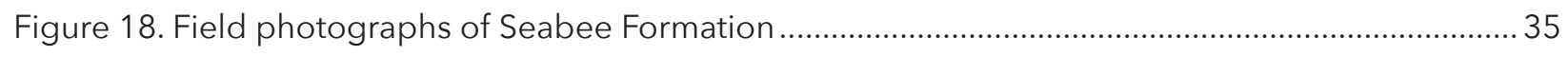

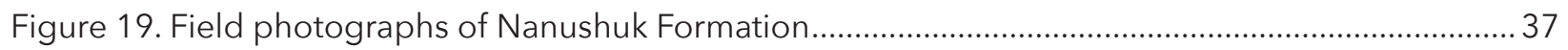




\section{Appendix 1}

Table A1. List of exploration wells in the Umiat-Gubik area..

Appendix 2

Table A2. Spreadsheet of fracture data employed in the Colville River corridor structural analysis of this study 



\title{
GEOLOGIC MAP OF THE UMIAT-GUBIK AREA, CENTRAL NORTH SLOPE, ALASKA
}

Trystan M. Herriott, ${ }^{1}$ Marwan A. Wartes, ${ }^{1}$ Paul L. Decker, ${ }^{2}$ Robert J. Gillis, ${ }^{1}$ Diane P. Shellenbaum, ${ }^{2}$ Amanda L. Willingham, ${ }^{1}$ and David J. Mauel ${ }^{3}$

\begin{abstract}
A new 1:63,360-scale geologic map of the hydrocarbon-bearing Umiat-Gubik area of the central North Slope, Alaska, spans approximately $2,100 \mathrm{~km}^{2}$ at the northern extent of the Brooks Range foothills fold-and-thrust belt in the Colville foreland basin. This geologic map was prepared through assimilation of field observations, aerial and satellite imagery, seismic-reflection data, and well logs. Near-surface formation picks were available or derived for most of the area's 24 exploration wells, and two cross sections were constructed along lines of section that are constrained at depth by our interpretations of publicly available two-dimensional seismic data.

The mapped area hosts exposures of Upper Cretaceous strata in the Nanushuk, Seabee, Tuluvak, Schrader Bluff, and Prince Creek Formations, constituting an approximately 2-km-thick succession that crops out discontinuously in the low-relief, tundra-mantled region. This part of the siliciclastic Brookian megasequence stratigraphy comprises principally shallow-marine deposits. Our work benefits from and reflects recent sequencestratigraphic advances that better constrain how this part of the Colville basin continued to fill by a northeastward prograding clastic wedge during Late Cretaceous time, with the exposed stratigraphy recognized as basin-scale topset units.
\end{abstract}

A series of east- to east-southeast-trending, $\mathrm{km}$-scale wavelength, gentle folds are mapped in the area. Anticlines are locally breached by thrusts and interpreted to be folded above faulted and penetratively deformed mid-Cretaceous Torok Formation. Undeveloped, subcommercial (as of this writing) petroleum accumulations occur along doubly plunging anticlinal traps at three long-recognized fields in the map area: Umiat (mostly oil), Gubik (gas), and East Umiat (gas). The Umiat oil field structural culmination is modified by thrust faults that breach the surface, and the East Umiat gas field is associated with a northdipping back-thrust that is evident in seismic data and cuts across the Upper Cretaceous stratigraphy; thrust faults near the Gubik gas field lie within and below the Torok Formation. Various interpretations have previously been published for some of the area's structures, with important implications for petroleum trap geometries in the gas-prone foothills region. We present new data and interpretations that support the inference of a principal, south-dipping thrust fault that breaches the north limb of Umiat anticline near Umiat. Additionally, a new fracture dataset addresses the previously hypothesized Colville fault. Ultimately, we do not find compelling evidence for a through-going, left-lateral strike-slip fault along the Colville River valley, which extends obliquely across the structural grain of the region. The fracture data are, however, generally consistent with a pure shear model of deformation associated with north-south contraction of the central Brooks Range foothills fold-and-thrust belt.

\footnotetext{
${ }^{1}$ Alaska Division of Geological \& Geophysical Surveys, 3354 College Road, Fairbanks, Alaska 99709-3707

${ }^{2}$ Alaska Division of Oil and Gas, 550 West $7^{\text {th }}$ Avenue, Suite 1100, Anchorage, Alaska 99501-3560

${ }^{3}$ Formerly at Alaska Division of Geological \& Geophysical Surveys, 3354 College Road, Fairbanks, Alaska 99709-3707
} 


\section{INTRODUCTION}

The Alaska Divisions of Geological \& Geophysical Surveys (DGGS) and Oil and Gas (DOG) conducted field studies near Umiat, Alaska (fig. 1), examining the region's Cretaceous stratigraphy and structural geology. Geologic mapping was an integral component of this fieldwork and is the foundation for a new 1:63,360-scale geologic map (sheet 1) that encompasses approximately $2,100 \mathrm{~km}^{2}$ of the central North Slope in the Brooks Range foothills fold-and-thrust belt (figs. 1 and 2). The North Slope is a large and prolific hydrocarbon province (for example, Bird and Houseknecht, 2011) that hosts the largest oil field in North America at Prudhoe Bay (for example, Magoon, 1994). Umiat is approximately $180 \mathrm{~km}$ southwest of Prudhoe Bay (fig. 1) and lies immediately south of the Umiat oil field (Collins, 1958; Molenaar, 1982; Hanks and others, 2014), which was discovered in 1946 and remains undeveloped. Two undeveloped gas fields-Gubik (Robinson, 1958) and East Umiat (for example, Kumar and others, 2002) —also occur in the study area, which is referred to as the Umiat-Gubik area in this paper, and were similarly discovered in the mid- $20^{\text {th }}$ century.

The Umiat-Gubik area is characterized by low-relief, treeless hills (fig. 3A) south of the Arctic coastal plain. Locally excellent outcrops (figs. 3B and C) permit observation of Upper Cretaceous Brookian megasequence strata of the dominantly marine Nanushuk, Seabee, Tuluvak, and Schrader Bluff Formations and the chiefly nonmarine Prince Creek Formation (fig. 4). This stratigraphy records a continued phase of primarily northeast-directed, basin axial sedimentation in the Colville foreland basin, which formed and began filling in the Jurassic(?)-Early Cretaceous in response to orogenic thickening in the ancestral Brooks Range (for example, Mull, 1979, 1985; Bird and Molenaar, 1992; Moore and others, 1994; Houseknecht and others, 2009; Bird and Houseknecht, 2011).

Umiat-Gubik and surrounding areas have long been recognized for their importance to understanding the geologic evolution of northern
Alaska, with pioneering work led by the U.S. Geological Survey (USGS) (for example, Schrader, 1904; Gryc and others, 1951, 1956; Detterman and others, 1963; Brosgé and Whittington, 1966). Recent investigations by USGS, DGGS, DOG, and university geologists build on the public-domain geologic framework established by these earlier studies and those of the intervening years (for example, Molenaar, 1982; Gryc, 1988), further elucidating the foreland basin's geology (for example, Mull and others, 2003, 2004; Houseknecht and Schenk, 2005; Decker, 2007; Flores and others, 2007a, 2007b; LePain and others, 2009; Flaig, 2010; Flaig and others, 2011, 2013, 2014; Shimer, 2013; Hanks and others, 2014; Sanders, 2014; Shimer and others, 2014, 2016; Wentz, 2014; van der Kolk and others, 2015; van der Kolk, 2016). Additionally, renewed exploration of the Umiat oil field (for example, Lidji, 2015a) and diminished throughput in the TransAlaska Pipeline System (for example, Bailey, 2016) have recently underscored the resource potential and economic significance of known petroleum accumulations despite market and technical challenges (for example, Lidji, 2016).

The remainder of this introduction outlines previous geologic mapping in the area and the methods employed during the current study; we also include a brief history of federal exploration programs in the region and general descriptions of the petroleum accumulations in the mapped area. The subsequent sections address the structural geology and stratigraphy of the area, providing a broader context for this work. Sheet 1 presents the 1:63,360-scale Umiat-Gubik area geologic map, a list and correlation of map units, and cross sections $\mathrm{A}-\mathrm{A}^{\prime}$ and $\mathrm{B}-\mathrm{B}$ ', which are accompanied by interpreted and non-interpreted, public-domain, two-dimensional seismic profiles.

\section{Previous Geologic Mapping of the Umiat-Gubik Area}

Detterman and others (1963) and Brosgé and Whittington (1966) mapped the geology of the Umiat region southeast and northwest of the Colville River, respectively. These 1:125,000-scale 


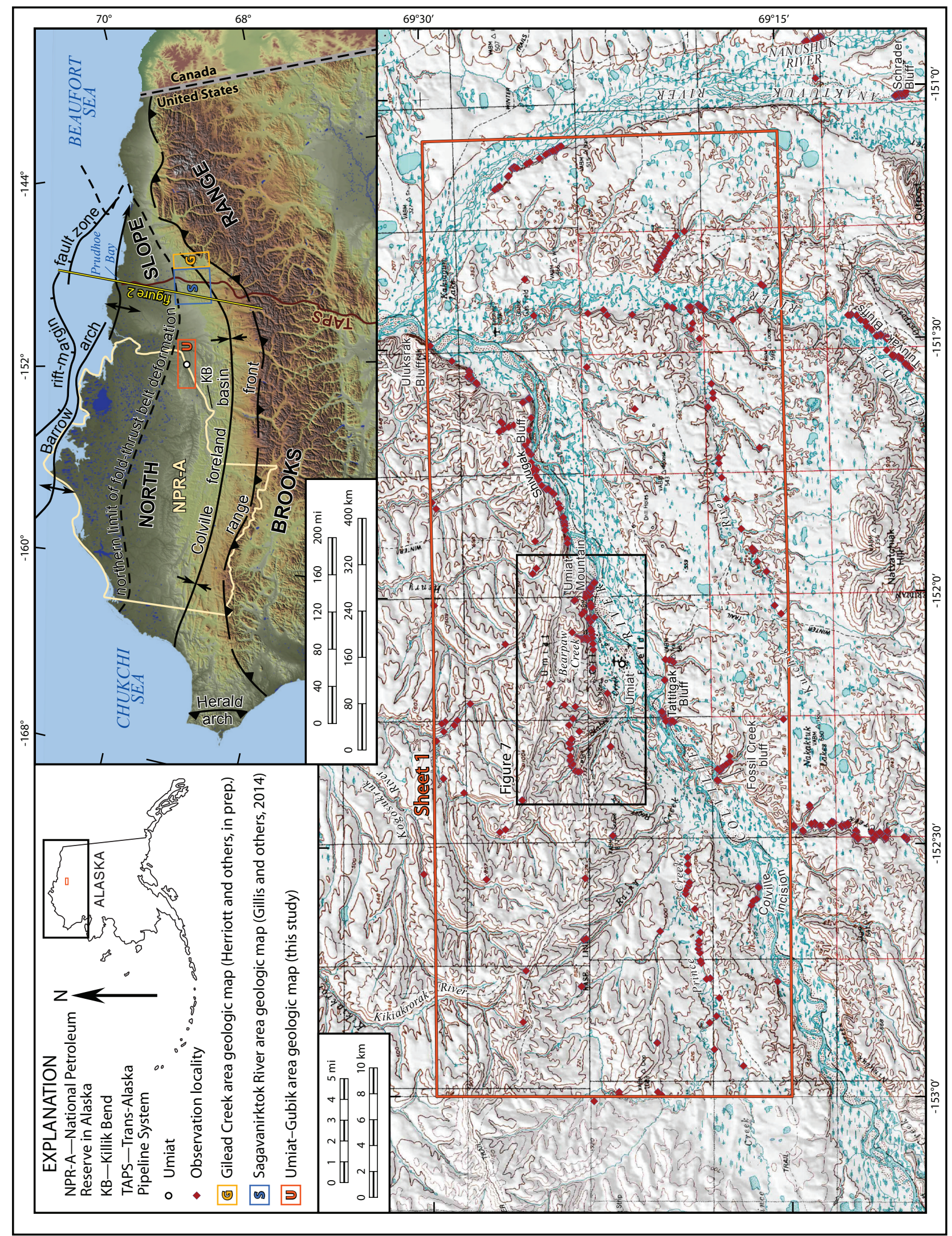

눙

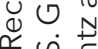

वंग

$\stackrel{0}{0}$

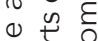

$+\frac{1}{\pi}$

$\leq \frac{2}{\varepsilon}$

气

每

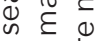

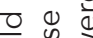

बin

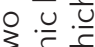

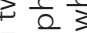

잉

응

으워

过

ब

음

8 ㅇำ

i $\frac{0}{6}$

तै

$\frac{0}{0} \pi$

赵

ข

ญे $\frac{0}{0}$

¿

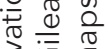

टें है

离

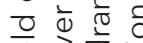

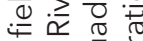

흥 긍 중

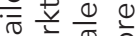

造

충

๗ँ

ब

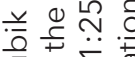

更

ज 0

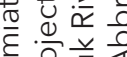

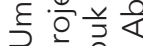

(1) 음

을

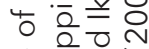

윰 $\stackrel{0}{\sigma} \frac{\square}{\sigma}$

है $\frac{\varepsilon}{\pi}=$

응 응

○ ब बे

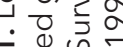

凶拧

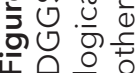




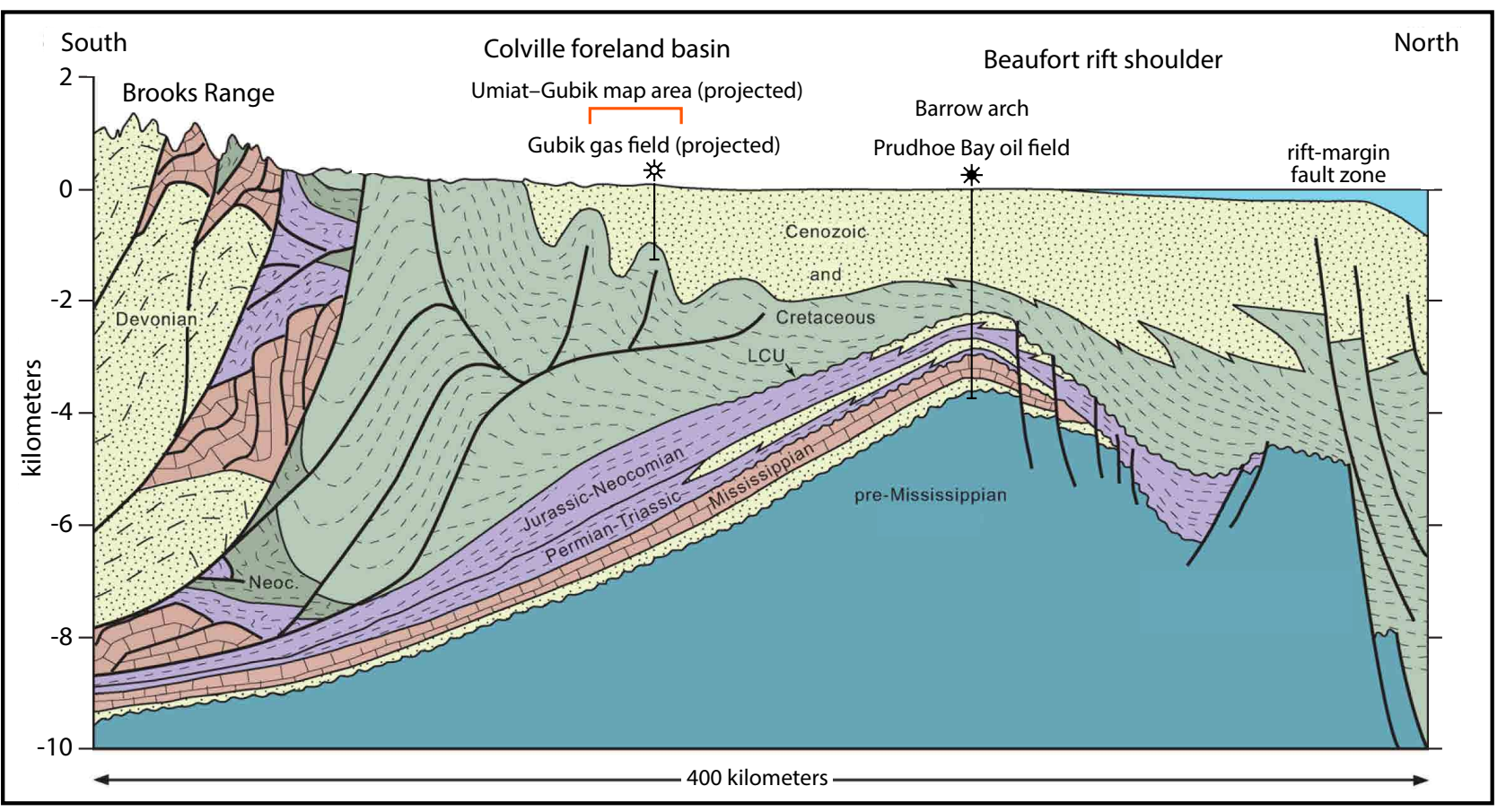

Figure 2. Schematic cross section of the Brooks Range and North Slope from Bird and Houseknecht (2011; modified from Bird and Bader, 1987). See figure 1 for section location. Abbreviation: LCU-Lower Cretaceous unconformity.

geologic maps incorporated extensive stratigraphic and structural studies and early petroleum exploration data (see discussion of Pet-4 program below). Mull and others (2004) subsequently published a 1:250,000-scale geologic map of the Umiat Quadrangle, incorporating the stratigraphic revisions of Mull and others (2003). Application of revised stratigraphic units influenced how the UmiatGubik area was mapped and understood, most notably with respect to the Schrader Bluff Formation; we discuss the implications of these revisions below. Mull and others (2004) also reported new structural interpretations for the Umiat Quadrangle, some of which are addressed in this paper.

\section{Present Study-Geologic Mapping and Methods \\ Field Campaigns and Outcrop Mapping}

We conducted two field campaigns in the Umiat-Gubik area, mapping the geology of the Umiat B-5, B-4, B-3, and westernmost part of B-2 quadrangles (1:63,360-scale) on paper topographic maps and approximately 1:60,000-scale aerial photographs (Alaska High Aerial Photography [AHAP] circa 1978-1982). Base camps for these field seasons were set up near the airstrip at Umiat. Field mapping was principally completed with helicopter transportation between widely

Figure 3, opposite page. Photographs exhibiting typical terrain and locally excellent outcrop character of the Umiat-Gubik study area. A. View of tundra and low-relief hills in headwaters region of Kikiakrorak River. This landscape hosts limited outcrops and characterizes most of the mapped area. B. Oblique aerial view eastward of Shivugak Bluff, exposing Schrader Bluff and Prince Creek Formations. This bluff and others along the Colville River provide the largest outcrops in the study area. Topographic relief of bluff is $\sim 120 \mathrm{~m}$, for sense of scale. C. View northward of Schrader Bluff Formation (Barrow Trail Member) along the west bank of the Chandler River. Similar low-relief but excellent cutbank exposures locally occur near rivers and creeks in the map area. Hammer is $31 \mathrm{~cm}$ long (see magenta outline). D. View southeastward of Schrader Bluff Formation (Barrow Trail Member) rubble-crop and outcrop surrounded by tundra of the upper Kogosukruk River area, with a curvilinear rib of subcrop extending to the left-skyline. This and similar traceable beds are evident along the flanks of Umiat anticline northwest of the Colville River, serving as important constraints to our interpretive geologic mapping. Photographs by T.M. Herriott. 

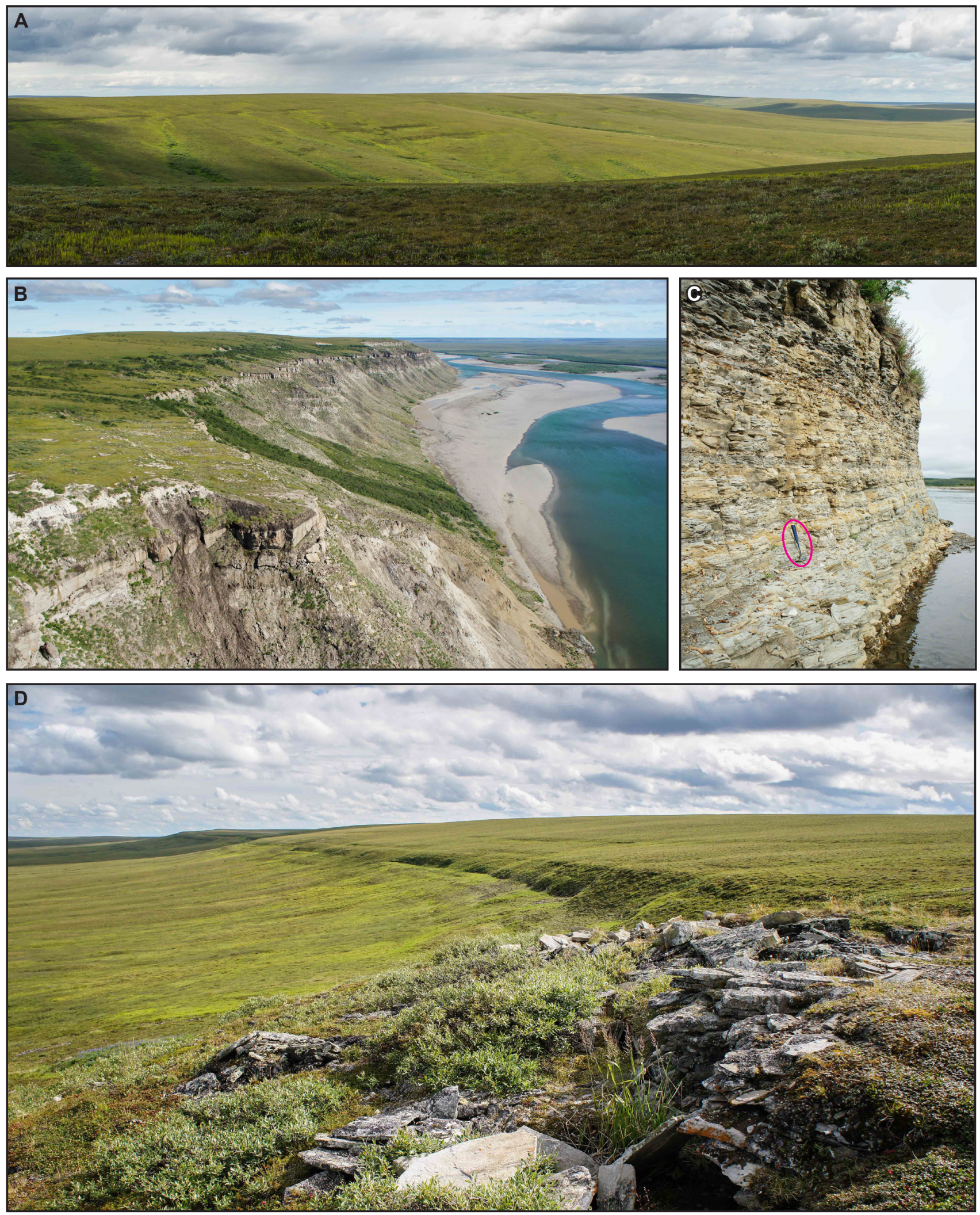


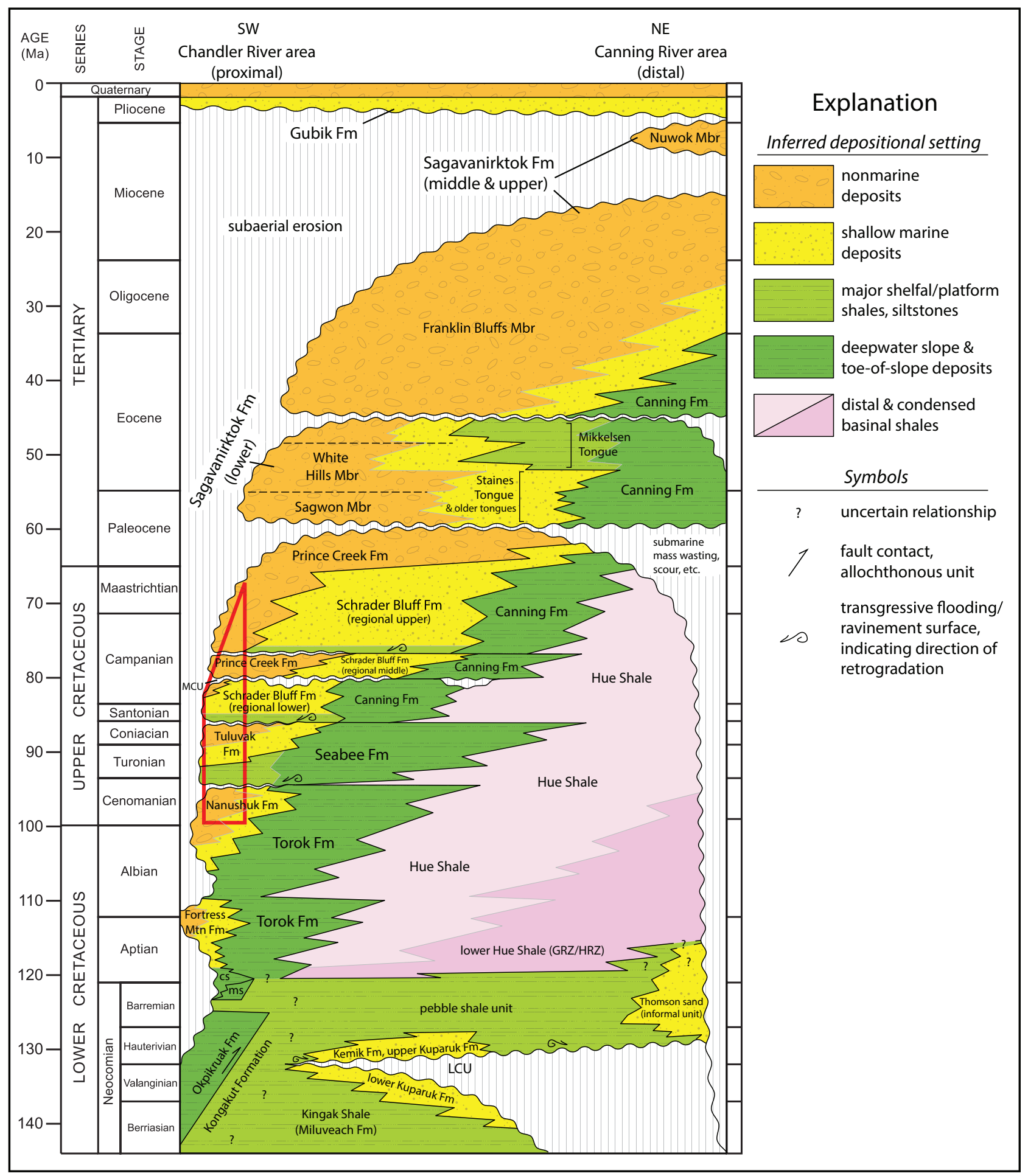

Figure 4. Colville foreland basin chronostratigraphic column from Decker (2010) and Gillis and others (2014) (revised from Mull and others [2003] and Garrity and others [2005]). The stratigraphy that crops out in the Umiat-Gubik area is outlined in red. Parts of three major Brookian depositional cycles occur in the mapped area: Nanushuk-Torok, TuluvakSeabee, and Prince Creek-Schrader Bluff-Canning (see text for further discussion). Schrader Bluff Formation members of this study constitute the regional lower part of the formation. Abbreviations: cs-Cobblestone sandstone (informal unit), Fortress Mountain Formation; Fm-Formation; GRZ/HRZ-gamma ray zone/highly radioactive zone; LCU-Lower Cretaceous unconformity; Mbr-Member; MCU-mid-Campanian unconformity (Decker, 2007); ms-manganiferous shale unit (informal unit); Mtn-Mountain. 
spaced outcrops. We traversed on foot any laterally extensive or closely spaced outcrops. The Cretaceous stratigraphy commonly crops out along cutbanks of the Anaktuvuk, Chandler, Colville, Kogosukruk, and Kutchik Rivers as well as Prince Creek and several unnamed drainages (figs. 1 and 3C; sheet 1); these exposures typically extended for tens or hundreds of meters. Important $\mathrm{km}$-scale outcrops that expose more than 100 $\mathrm{m}$ of stratigraphy occur along the Colville River at Shivugak, Tattitgak, and Uluksrak Bluffs, the south face of Umiat Mountain, and the informally named Colville incision locality (in the sense of LePain and others, 2009) (figs. 1 and 3B; sheet 1). Tundra-mantled uplands constitute most of the field area and are generally devoid of outcrops, but curvilinear trends of subcrop, rubble-crop, and outcrop occur in hilly terrain northwest of the Colville River (fig. 3D) and were mapped on aerial photographs and satellite imagery. We fieldchecked many of these traceable beds, which serve as excellent stratigraphic markers that are locally correlated to bluff-scale outcrops, rendering high-confidence stratigraphic and structural constraints in otherwise covered areas.

Geologic mapping from the field campaigns was compiled, scanned, georeferenced, and digitized in ESRI ArcGIS ArcMap software. The mapped surficial geology of sheet 1 is limited to alluvial deposits associated with modern rivers and creeks and simplified from Carter and Galloway (1986). Outcrop distribution is demarcated by map unit polygons with hatched fill (sheet 1). The large, non-hatched swaths of map units that extend across sheet 1 represent the interpreted distribution of the stratigraphy.

\section{Interpretive Geologic Mapping}

Limited bedrock exposures occur in the study area, but the distribution of outcrops, character of the deformation, and exploration data permit interpretative geologic mapping of units that generally lie beneath a thin veneer of tundra. Previous workers have published interpre- tive geologic maps of this region (Detterman and others, 1963; Brosgé and Whittington, 1966; Mull and others, 2004), but sheet 1 is the first geologic map of the Umiat-Gubik area that distinguishes between outcrop and interpreted bedrock geology.

To complete the interpretive mapping, we integrated numerous datasets, including field observations, aerial and satellite imagery, seismic-reflection data, and well logs. Twenty four exploration wells (appendix 1) and numerous seismic surveys have been completed in the Umiat-Gubik area during the past approximately 70 years. We examined well logs and two-dimensional and three-dimensional seismic data (public and confidential), picking formation tops and interpreting structures (fold axial surfaces and fault planes) throughout the mapped area's subsurface. ${ }^{4}$ Axial surfaces of $\mathrm{km}$-scale folds evident in the seismic data were projected to their intersections with topography and used to refine axial traces for the folds that were principally identified and/ or inferred from field observations. Faults were also interpreted in the seismic data, but were only projected to the surface and mapped on sheet 1 where they cut across the shallowest resolved intervals of the seismic data (typically several hundred meters below the surface). In areas of structural complexity where three-dimensional seismic data were available (for example, the Umiat oil field) we interpreted dip-parallel seismic sections at hectometer-scale spacing. All structures that were identified with, or were better located by, seismic-reflection data are plotted in magenta on sheet 1 .

The seismic data do not permit identification of near-surface stratigraphic units, although the stratigraphy identified at greater depths provided important constraints. In mapping the interpreted geologic map unit contacts, we utilized the outcrop mapping described above, bedding orientation data (this study), structural mapping (Brosgé and Whittington, 1966; Molenaar, 1982; Kumar and others, 2002; this study), and known stratigraphic thicknesses (Collins, 1958; Robinson, 1958; Detterman

\footnotetext{
${ }^{4}$ Seismic and well data from qualifying industry exploration conducted within the study area since 2007 were released by the Alaska Department of Natural Resources in 2017 and 2018, including three-dimensional seismic surveys at the Umiat and Gubik fields. Contact DGGS or DOG for further information regarding these now publicly available tax-credit data.
} 
and others, 1963; Brosgé and Whittington, 1966; DGGS, unpublished data). We also employed uppermost formation picks made by Kenneth J. Bird (U.S. Geological Survey, written communication, 2010) and publicly available well completion reports from the Alaska Oil and Gas Conservation Commission (AOGCC), Collins (1958), and Robinson (1958) (appendix 1). The interpretive mapping was an iterative process, refined and corroborated by examination of the multiple data sources noted here. However, the interpretive contacts are generally marked as inferred (shortdashed lines) except where they are constrained by nearby outcrops or subcrop, where they are designated as approximately located (long-dashed lines).

Note that local seismic data interpreted in this study were converted from travel time to approximate depth for illustrative purposes using a simple velocity field interpolated from wells tied to the seismic data. Seabee Test No. 1 and Gubik No. 4 wells' time-depth relations significantly influenced the depth conversions. More rigorous depth conversion techniques would be appropriate for planning wells or detailed reservoir analyses.

\section{Cross Sections}

Cross sections A-A' and B-B' (sheet 1) were similarly constructed though the integration of our field geologic mapping and subsurface data. The subsurface geology of A-A' is based on our interpretation of the public-domain, two-dimensional seismic line U8-78 (Triezenberg and others, 2016); the line of section is coincident with the seismic line (fig. 5). The near-surface seismic character of U8-78 does not permit identification of formation tops above the Nanushuk Formation to the south, the Torok Formation near the Umiat anticline's crest, and the Seabee Formation to the north. Geologic mapping and known stratigraphic thicknesses were compared to and combined with the seismic interpretation to complete A-A'. A similar approach was employed for B-B', which in the subsurface is based on the public-domain, two-dimensional seismic line 720-80 (Triezenberg and others, 2016); the line of section nearly coincides with the seismic line (fig. 5). The Tuluvak
Formation top is the uppermost formation pick for most of 720-80 along B-B', with none of the Schrader Bluff Formation members readily identifiable in the seismic data. The near-surface interpretation for the Rogers Creek, Barrow Trail, and Sentinel Hill Members (Schrader Bluff Formation) and the Prince Creek Formation of B-B' is based on geologic mapping and stratigraphic thickness constraints (see below). Non-interpreted and linedrawing interpretations for the two seismic sections are presented on sheet 1 . The cross sections are not line or area balanced.

\section{Overview of Petroleum Geology in the Umiat-Gubik and Surrounding Areas}

Documentation of oil seeps along the northern coast of Alaska dates to the early $20^{\text {th }}$ century (Brooks, 1916; Leffingwell, 1919), which contributed to the establishment of Naval Petroleum Reserve No. 4 (NPR-4) in 1923 (see NPR-A on fig. 1). Early geologic reconnaissance of the petroleum reserve was conducted by the USGS during 1923-1926 (Smith and Mertie, 1930). An initial phase of exploration in NPR-4 was led by the U.S. Navy in collaboration with the USGS, beginning in 1944 as a strategic response to the energy needs of World War II (Reed, 1958). During this program, which was referred to as Pet-4, the USGS completed regional geologic studies in and beyond NPR-4, including the geologic mapping of Detterman and others (1963) and Brosgé and Whittington (1966). The work also included an extensive drilling program and geophysical surveys. Three oil fields and five gas fields were discovered, including the Umiat (dominantly oil) and Gubik (gas) fields that lie in the current map area, and Pet-4 concluded in 1953. Subsequent industry-led drilling in the mid-1960s led to the discovery of a third petroleum accumulation in the mapped area, the East Umiat gas field (see Molenaar, 1982).

A second federal exploration program in NPR-4, renamed the National Petroleum Reserve in Alaska (NPR-A) in 1977, was conducted from 1974 through 1981 . The program included drilling 28 test wells. One of these wells, Seabee Test No. 


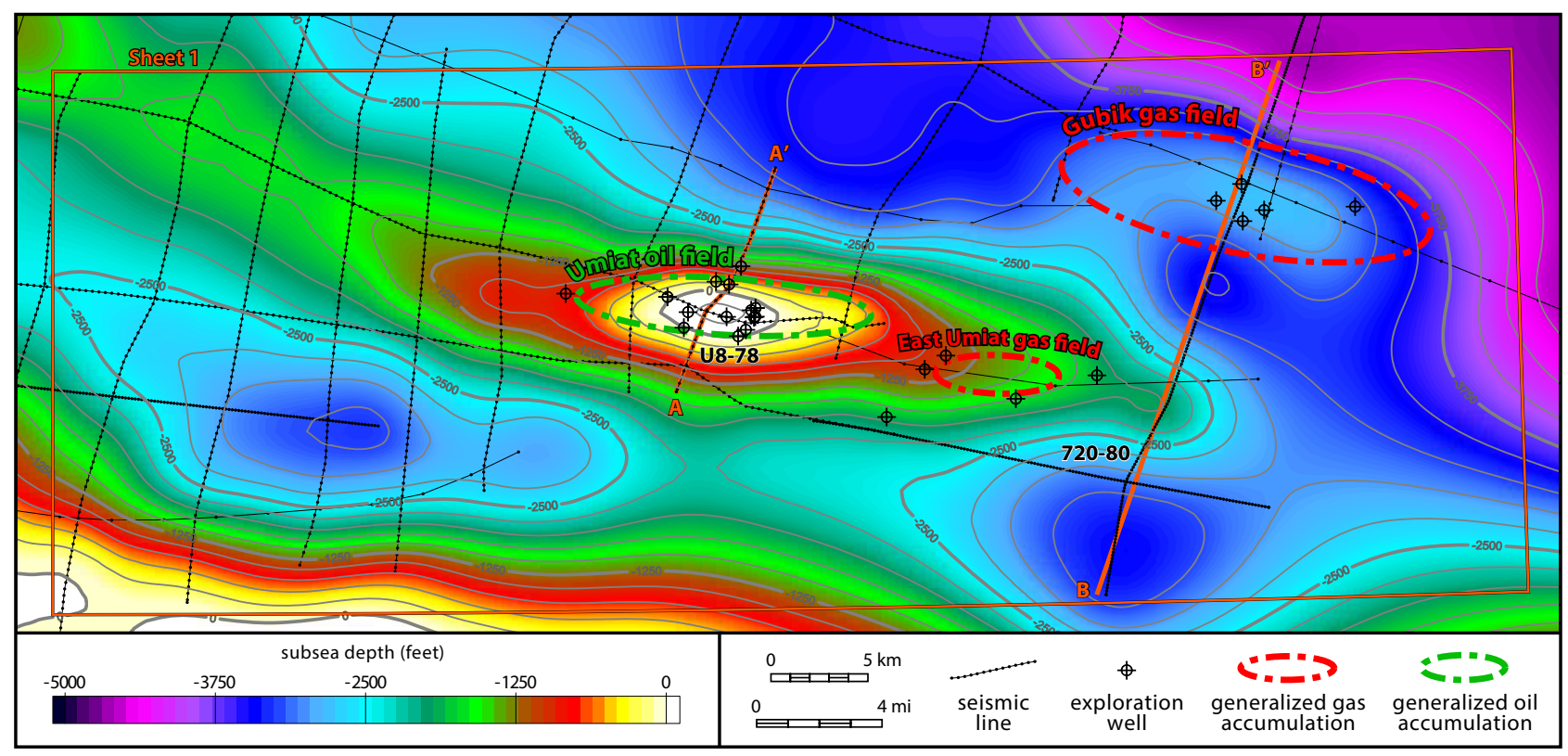

Figure 5. Depth structure map of Umiat-Gubik map area based on publicly available seismic data grid shown in thin black lines with shot points. Reference datum is top Nanushuk Formation. Note that oil and gas field outlines are generalized (see also Division of Oil and Gas, 2008). See figure 1 for index map.

1 (appendix 1), was drilled at the Umiat oil field, penetrated Lower Cretaceous Brookian intervals (for example, Molenaar, 1982) and had numerous oil and gas shows (sheet 1: cross section A-A', Umiat oil field detail). Similar to the Pet-4 phase of exploration, extensive geologic and geophysical surveys were conducted throughout and beyond NPR-A. USGS Professional Paper 1399 (Gryc, 1988) presented the geologic and geophysical work of this latest government-led exploration program in NPR-A. Extensive summaries of the U.S. Navy and USGS work in NPR-4/NPR-A are presented by Smith and Mertie (1930), Reed (1958), Bird (1981), and Schindler (1988).

\section{Hydrocarbon \\ Accumulations in the Mapped Area}

The region's Mesozoic stratigraphy hosts numerous petroleum source rocks, including the Shublik Formation, Kingak Shale, pebble shale unit, Hue Shale, and Torok Formation (for example, Magoon and Bird, 1985; Magoon, 1994; Houseknecht and Bird, 2006). All of these units lie in the Umiat-Gubik area subsurface (see sheet 1 cross sections). Petroleum generation, migration, and trapping in the central Brooks Range fold-and-thrust belt is generally interpreted to be tied to tectonic burial, sedimentation, and deformation of the Brooks Range and Colville foreland basin during mid-Cretaceous to Paleocene time ( -120-60 Ma) (for example, Bird and Houseknecht, 2011). Many of the structural traps in the central foothills are $\mathrm{km}$-scale anticlines, locally modified by thrust faults, that likely formed at approximately $60 \mathrm{Ma}$ (for example, O'Sullivan and others, 1997; Moore and others, 2004). Petroleum systems modeling of the central fold-andthrust belt suggests a main phase of mid-Cretaceous oil generation followed by additional Late Cretaceous burial and Paleocene structural trap formation, rendering a generally gas-prone region (see Bird and Houseknecht, 2011). We refer the interested reader to Magoon (1994), Magoon and others (2003), Moore and others (2004), Houseknecht and Bird (2006), Peters and others (2006), and Bird and Houseknecht (2011) for further information regarding petroleum systems evolution in northern Alaska.

The Umiat-Gubik area petroleum accumulations (fig. 5) occur along doubly plunging, gently folded (fig. 6) anticlinal traps; hydrocarbon accu- 


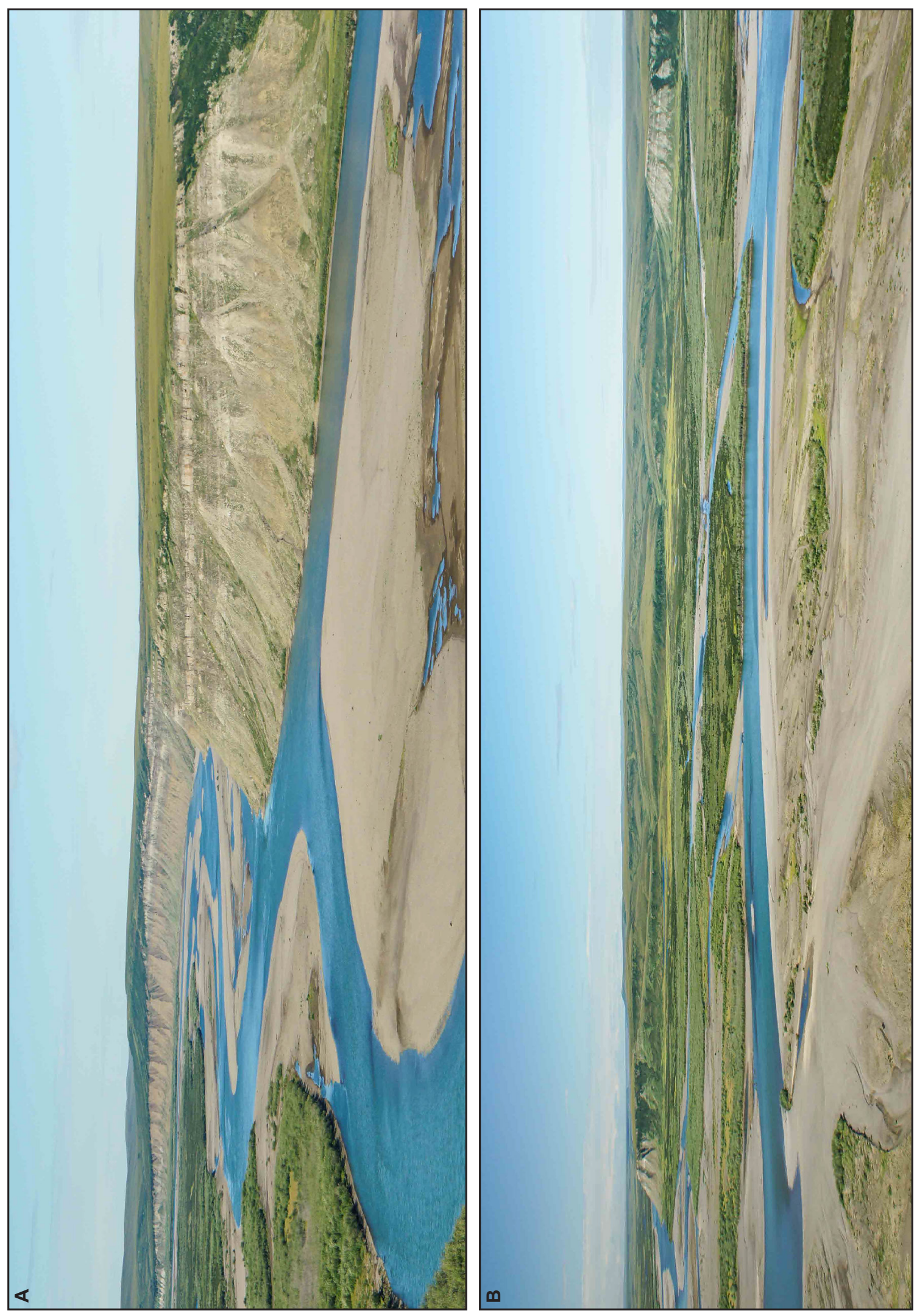

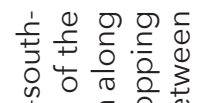

ผे

0.

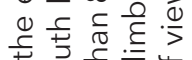

to

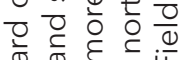

3 .

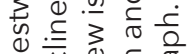

$3 \div \cdot \frac{0}{3} \frac{0}{0}$

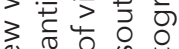

$>+\pi 000$

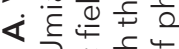

هं

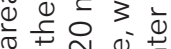

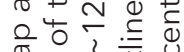

$\stackrel{\pi}{\varepsilon}$ 을.

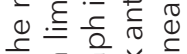

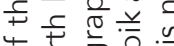

응

तु

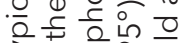

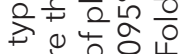

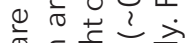

的家

䓠 윰

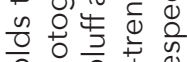

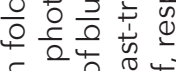

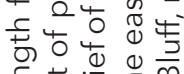

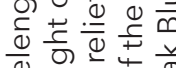

$\stackrel{0.0}{0.0}$

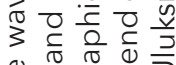

(1)

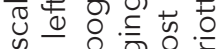

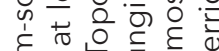

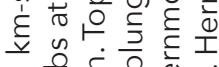

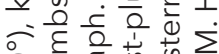

을

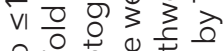

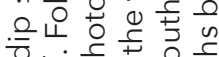

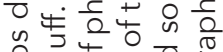

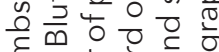

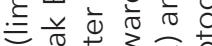

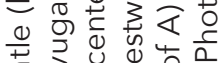

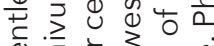

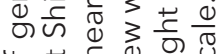

प艹

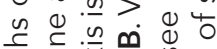

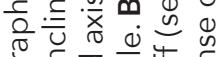

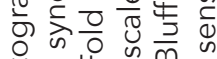

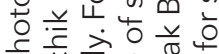

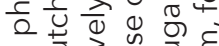

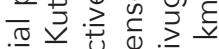

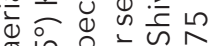

ণ in 过的

d

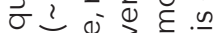

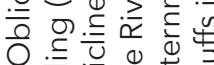

O

०

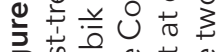

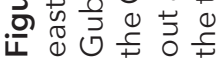


mulations are in the Nanushuk Formation and younger Cretaceous stratigraphy that is folded over structurally thickened Torok Formation. Both the Umiat and East Umiat fields are modified by thrust faults (Brosgé and Whittington, 1966; Molenaar, 1982; Kumar and others, 2002; this study).

\section{Umiat Oil Field}

The Umiat oil field (fig. 5) was the first oil accumulation discovered on the North Slope. The field lies along a faulted extent of the Umiat anticline north of Umiat (sheet 1). Eleven wells were drilled into Nanushuk Formation reservoir targets during 1945-1952, with discovery of the oil field in Umiat Test No. 3 in 1946 (Collins, 1958; Molenaar, 1982; Bird and Bader, 1987). As noted above, an additional well (Seabee Test No. 1) was drilled several decades after the oil field had been discovered. Renewed industry exploration of the Umiat field has been ongoing during the past decade, with the acquisition of a three-dimensional seismic survey in 2008 (Watt and others, 2010) and new wells drilled during 2013 (Umiat No. 18) and 2014 (Umiat No. 23H) (see Lidji, 2015a, 2016; appendix 1). Estimates of recoverable oil resources discovered at the Umiat field range between many tens and several hundred million barrels (see Lidji, 2012, 2015b), with a commonly cited value of 70 million barrels (Molenaar, 1982). Geologic modeling by Hanks and others (2014) indicated 1.52 billion barrels of original oil in place at the Umiat field, with 99 billion cubic feet of associated gas, and these authors presented a reservoir simulation analysis that suggested an oil recovery efficiency of $12-15 \%$ through 50 years of modeled production. The oil source rock in the Umiat accumulation is probably the lowermost Brookian gamma ray zone (GRZ)/ highly radioactive zone (HRZ) of the Hue Shale (Magoon and others, 2003; fig. 4). The main oil reservoirs in the Umiat field are Albian delta front and shoreface sandstones (Molenaar, 1982; Hanks and others, 2014; Shimer and others, 2014) of the Nanushuk Formation (the Grandstand Formation of former usage) (Collins, 1958; Molenaar, 1982).
Hanks and others (2014) reported an API (American Petroleum Institute) gravity of $37^{\circ}$ for Umiat oil, and the reservoirs are mostly in permafrost. The locally doubly plunging anticline provides, in combination with thrust truncation (sheet 1: cross section $A-A^{\prime}$, Umiat oil field detail), structural closure over an area of approximately 7,500 acres (Kumar and others, 2002).

Oil shows and oil produced on tests suggest that the Umiat field oil column extends above the main reservoir sandstones (transitional marine and nonmarine Nanushuk Formation interval formerly recognized as upper Grandstand Formation) into lower-reservoir-quality sandstones (fully marine Nanushuk Formation interval formerly recognized as Ninuluk Formation). ${ }^{5}$ As noted by Molenaar (1982), there is insufficient information from the wells to define a precise oil-water contact, and there is at least local evidence for reservoir compartmentalization and separate fluid contacts in upper and lower Grandstand sandstones. Molenaar (1982) estimated the oil-water contact in the upper Grandstand on the southern flank of the structure at about -650 feet subsea, between the Umiat Test No. 6 (oil productive) and the Umiat Test No. 7 (wet) wells. This is broadly consistent with the bottom of persistent oil shows and resistivity log response observed in the Seabee Test No. 1 well at -440 feet subsea (see sheet 1: cross section A-A', Umiat oil field detail). The top of the upper Grandstand reservoir horizon is mapped (Brosgé and Whittington, 1966; Watt and others, 2010) as having a crestal depth of approximately +250 feet subsea (that is to say, 250 feet above sea level), yielding a potentially productive oil column in the main reservoir interval of about 690-700 feet. This main reservoir interval is the lower part of the thicker, generalized oil column of cross section A-A' (sheet 1: Umiat oil field detail), which includes the Ninuluk interval noted above.

\section{Gubik Gas Field}

The Gubik gas field (fig. 5) was discovered in 1951 when two wells (Gubik Test Nos. 1 and 2; appendix 1) were drilled following delineation

\footnotetext{
${ }^{5}$ See Mull and others (2003) for former and current Nanushuk Formation stratigraphic nomenclature.
} 
of the Gubik anticline (fig. 6B and sheet 1) by geologic and geophysical studies during 19451950 (Robinson, 1958; Bird and Bader, 1987). One additional well was drilled on the Gubik anticline during industry activity in 1963, and two industry wells were completed in 2008 and 2009 (appendix 1). Recoverable gas resources at Gubik are estimated at 600 billion cubic feet (Kornbrath and others, 1997) and hosted largely by the Tuluvak Formation (Robinson, 1958; Mull and others, 2003). This gas may be sourced from the gas-prone, terrestrial kerogen-rich Torok Formation, as has been proposed for the Aupuk gas seep southwest of the current study area (Decker and Wartes, 2008). The doubly plunging anticline provides structural closure over an area of approximately 20,000 acres and 800 vertical feet (Kumar and others, 2002; see also Robinson, 1958).

\section{East Umiat Gas Field}

The East Umiat gas field (fig. 5) was discovered during industry drilling in the winter of 1963-1964 (Molenaar, 1982; Bird and Bader, 1987). Three additional wells were completed in the following decade and a fifth well was drilled in 2008-2009 (appendix 1). The field lies along the Umiat anticline east-southeast of the Colville River, and 4 billion cubic feet of recoverable gas resources were reported by Kornbrath and others (1997). Gas in the East Umiat field is hosted in numerous Nanushuk Formation intervals (Bird, 1988a; Kumar and others, 2002) and, similar to the Gubik gas field, may be sourced from the gas-prone Torok Formation. The locally doubly plunging anticline provides structural closure over an area of approximately 5,000 acres and less than 100 vertical feet (Kumar and others, 2002).

\section{STRUCTURAL GEOLOGY Regional Context-Brookian Orogenesis}

Structural, stratigraphic, and thermochronologic studies in northern Alaska indicate a longlived, multi-phase Brooks Range orogeny that spans the past approximately 175 million years (for example, Mull, 1982; Mayfield and others, 1988;
Bird and Molenaar, 1992; Moore and others, 1994, 2004; Blythe and others, 1996; Cole and others, 1997; Mull and others, 1997; O'Sullivan and others, 1997; Vogl and others, 2002). Middle Jurassic to Early Cretaceous contraction emplaced a series of thin-skinned allochthons that were progressively stacked in sequence from south to north along orogen-scale thrust faults, collapsing a south-facing passive margin that rifted to the north and collided with an oceanic island arc to the south (for example, Mull, 1982; Mayfield and others, 1988; Moore and others, 1994; Wallace, 2008). This thick succession of allochthons resulted in hundreds of kilometers of shortening, loading the lithosphere and driving subsidence in the Colville foreland basin to the north (see reviews by Bird and Molenaar, 1992; Moore and others, 1994). Cole and others (1997) reported that maximum tectonic loading was achieved in the Barremian. Uplift and extension exhumed part of the orogen's hinterland along south-dipping normal faults in the southern Brooks Range (Miller and Hudson, 1991) during mid-Cretaceous time ( $113-95 \mathrm{Ma}$; Blythe and others, 1996; Vogl and others, 2002; see also Turner and others, 1979), although contemporaneous contraction may have continued to the north (Oldow and others, 1987; Till, 1992; Moore and others, 1994; Till and Snee, 1995; Cole and others, 1997). This episode of mid-Cretaceous uplift likely marked the first subaerial exposure of the Brooks Range orogen (Wallace, 2008). The ancestral Brooks Range and regions farther west provided prolific source areas for large volumes of Aptian(?)-Cenomanian Nanushuk-Torok sediment that spilled north and east into the underfilled foreland basin (for example, Molenaar, 1985, 1988; Bird and Molenaar, 1992; Houseknecht and Schenk 2001; Houseknecht and others, 2009; Bird and Houseknecht, 2011). Post-Nanushuk-Torok Upper Cretaceous units accumulated during a period of apparent tectonic quiescence, which was followed by a later phase of renewed Brookian contraction at approximately $60 \mathrm{Ma}$ (Blythe and others, 1996; O'Sullivan and others, 1997; Mull and others, 1997; Moore and others, 2004). This Paleocene event propagated the fold-and-thrust 
belt into the foreland basin, including the UmiatGubik study area, rendering $\mathrm{km}$-scale uplift of the Upper Cretaceous stratigraphy (Blythe and others, 1996; O'Sullivan, 1996; Cole and others, 1997; O'Sullivan and others, 1997; Gillis and others, 2014). Episodic shortening and uplift continued in the east-central and northeastern Brooks Range during Paleogene time (for example, O'Sullivan, 1996; O'Sullivan and others, 1993, 1997, 1998; O'Sullivan and Wallace, 2002), and deformation in northeasternmost Alaska and outboard Beaufort Shelf remains ongoing today (Grantz and others, 1983, 1990; Moore and Box, 2016).

\section{Umiat-Gubik Area Structure}

The Umiat-Gubik study area lies in the northern part of the central Brooks Range foothills fold-and-thrust belt (figs. 1 and 2). We highlight two key aspects of the Brookian orogeny that bear directly on the structural geology of the UmiatGubik area. 1) Significant subsidence of the foredeep and its marked filling by Torok-Nanushuk depositional systems (for example, Molenaar, 1988; Houseknecht and Schenk, 2001; Houseknecht and others, 2009; LePain and others, 2009) rendered a mechanical stratigraphy comprising the approximately 3-km-thick, mud-prone Torok overlain by the thinner, approximately 300-m-thick, sandprone Nanushuk (thicknesses after Molenaar, 1982). This stratigraphic juxtaposition of mechanically weak (Torok) and rigid (Nanushuk) units strongly influenced the character of deformation in the foothills fold-and-thrust belt (for example, Moore and others, 2004; Wallace, 2008; Mull and others, 2009; Sanders, 2014). 2) The Upper Cretaceous stratigraphy of the study area was deformed during the approximately 60 Ma cooling event (see references above), with penetrative and thrust-related structural thickening in the Torok Formation and gentle detachment folding and thrusting of the overlying Nanushuk and younger formations (for example, Molenaar, 1982; Kirschner and Rycerski, 1988; Mull and others, 2004; Sanders, 2014; this study). These events and their timing were also critical to generation and trapping of oil and gas in the region (for example, Moore and others, 2004).
Five large (km-scale wavelength) folds are mapped in the study area (south to north): Fossil Creek anticline, Prince Creek syncline, Umiat anticline, Kutchik syncline (fig. 6A), and Gubik anticline (fig. 6B) (sheet 1; Detterman and others, 1963; Brosgé and Whittington, 1966; Mull and others, 2004). Structural relief across this fold train diminishes to the north and east (fig. 5), a trend that is reflected in the distribution of generally younger strata to the northeast. Only minimal deformation of the Upper Cretaceous stratigraphy is evident north of the study area, where the northern limit of deformation is delineated (for example, Mull and others, 2004; figs. 1 and 2). Folds in the map area generally plunge to the east-southeast, although many of these structures are locally doubly plunging and form traps at the Umiat, East Umiat, and Gubik hydrocarbon accumulations discussed above. Axial surfaces are chiefly upright or dip very steeply; anticlinal crests are locally truncated by north- or south-dipping thrust faults (sheet 1). Folds are gentle, with limbs principally dipping less than 10 degrees (fig. 6).

Anticlines in the area are recognized as detachment folds that are commonly thrust-modified (for example, Molenaar, 1982; Sanders, 2014). Consistent with the work by Sanders (2014), our seismic-based cross sections indicate a mid-Torok interval prone to forming imbricate fault arrays and duplexes over a probable lower Torok detachment interval, with north-dipping, passive-roof thrusts locally ramping into or entirely truncating an upper Torok interval (sheet 1: cross sections $\mathrm{A}-\mathrm{A}^{\prime}$ and B-B'). Mull and others (2004, 2005) highlighted that some anticlines of the central Brooks Range foothills fold-and-thrust belt are cut by north-dipping, breaching back-thrusts, a structural style that may be even more common near the range front to the south (for example, Mull and others, 2009); we interpret such a case near the East Umiat gas field (sheet 1: cross section B-B' at Umiat anticline). The Gubik anticline is not faulted at the surface, but our interpretation of seismic-reflection data indicates a back-thrust terminates in the upper Torok below the Gubik gas field (sheet 1: cross section B-B'). Our examination of seismic data that image 
the Fossil Creek anticline near the southwest bank of the Colville River suggests a locally complex structure with two anticline crests juxtaposed by a south-dipping thrust fault (sheet 1). Future investigations west and south of the study area may shed further light on the Fossil Creek anticline's faultfold association.

The following sections address the Umiat oil field area structural geology and the potential for a regional-scale, left-lateral strike-slip fault along the Colville River corridor. ${ }^{6}$ We review previous studies relevant to these areas and present new work that further constrains the structural relations, which have implications for the style of deformation and potential trap geometries in the gas-prone foothills fold-and-thrust belt.

\section{Umiat Oil Field Structure}

Faulting associated with the Umiat oil field has long been recognized, with seismic and well data from the 1940s revealing a fault-fold association (Collins, 1958; Brosgé and Whittington, 1966). North of the fold's axial trace, Brosgé and Whittington (1966) mapped a series of faults in a zone that is generally several hundred meters wide and associated with a prominent topographic lineament (fig. 7) defined by steeply north-dipping sandstone beds. The steep dips are anomalous, as the fold limbs chiefly dip gently in areas north and south of the lineament (sheet 1). Brosgé and Whittington (1966) also reported offset (downthrown to north -50 feet) of bench-forming Nanushuk Formation outcrops east of Bearpaw Creek (see sheet 1 and fig. 7) and remarked that this is the only "direct evidence of faulting" at the surface in their mapped fault zone. These authors ultimately described and portrayed a fault zone comprising a complex of south-dipping thrust faults rooted in the Torok, with up to 2,000 feet of stratigraphic separation across the zone. Molenaar (1982) built on the earlier work of Brosgé and Whittington (1966) and attributed the thrustfaulted Umiat anticline to detachment folding of the Nanushuk and Upper Cretaceous stratigraphy over faulted and penetratively deformed Torok. Similar to the previous geologic mapping of the area, Mull and others (2004) recognized structural significance in the topographic lineament, but rather mapped the feature as the breaching trace of a north-dipping back-thrust, noting that back-thrusts in the region commonly occur where Nanushuk Formation crops out near fold crests.

Our mapping of the Umiat anticline also documents that the limbs principally dip gently, with moderately to steeply dipping bedding near the topographic lineament (fig. 7 and sheet 1). We completed foot traverses along the approximately $15-\mathrm{km}$-long lineament, which we map as a north-dipping panel of Tuluvak Formation in the north limb of the anticline. The map pattern identifies juxtaposition of stratigraphic units across the lineament of the same formation, or, more commonly, a younger formation to the north, with the greatest stratigraphic separation near Bearpaw Creek and diminishing separation to the east and west (fig. 7 and sheet 1; compare with Brosgé and Whittington, 1966; Molenaar, 1982; Hanks and others, 2014).

We observed bedrock rubble with slickensides at two localities (11BG254 and near 11BG263) near the western end of the lineament, and two additional nearby locations (11BG269 and 11BG270) host faults in small outcrops (fig. 7). Numerous slip planes at these latter two localities exhibited grooves, shear steps defined by fibrous crystal growth, and serrated asperities produced by secondary shear steps on non-mineralized planes; these faults dominantly dip moderately to steeply to the north and south, with one fault dipping steeply eastward. Kinematic indicators at these outcrops principally suggest normal slip, with some of the fault planes closely paralleling or coinciding with bedding planes. Farther east, the Bearpaw Creek area reveals steeply dipping Tuluvak Formation strata defining the lineament and subhorizontal to gently dipping benches

\footnotetext{
${ }^{6}$ Note that the right-lateral strike-slip fault that we map along the Colville River near Umiat (see tear fault(?) of sheet 1) is of limited extent $(<5 \mathrm{~km})$ and is not an equivalent to the regional-scale, left-lateral strike-slip fault (that is to say, the Colville fault of Mull and others, 2004, 2005) discussed below.
} 


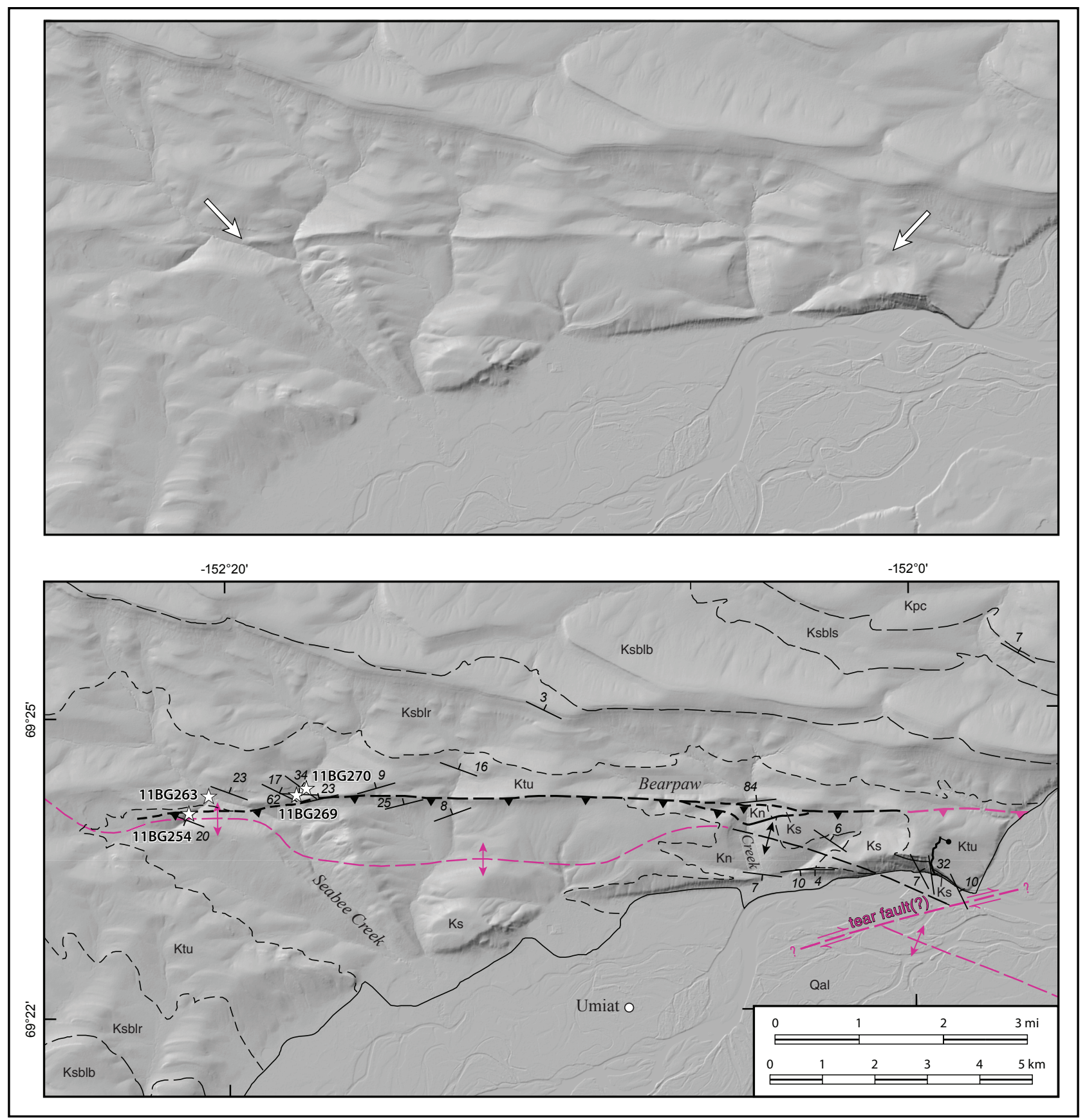

Figure 7. Interferometric synthetic aperture radar (IFSAR)-based shaded-relief map of Umiat anticline near Umiat. Note the prominent topographic lineament (see between arrows in A) and field localities (see stars in B) discussed in text. Geologic linework and symbols are from sheet 1; see figure 1 for index map.

of Nanushuk Formation cropping out several hundred meters to the south (sheet 1 and fig. 7); we do not map Seabee Formation along the creek (compare with Mull and others, 2004). Additionally, the bench-forming Nanushuk outcrops are distinctly offset (downthrown to north) immediately east of Bearpaw Creek as noted above. Within this context, we map a south-dipping thrust fault along the topographic lineament, with a splay fault offsetting the Nanushuk beds near Bearpaw Creek (sheet 1 and fig. 7).

We also reconnoitered a normal fault near Umiat Mountain (Houseknecht and Schenk, 2005; fig. 7 and sheet 1; compare to Brosgé and 
Whittington, 1966) that lies approximately 1 $\mathrm{km}$ southeast of the eastern end of the lineament (fig. 7). This fault dips approximately $45^{\circ}$ toward approximately $125^{\circ}$, has a $\mathrm{m}$-scale shear zone with locally boudinaged sandstone, and is associated with numerous smaller-scale normal-slip faults that dip moderately to steeply east/east-southeast and west/west-northwest, accommodate tens of centimeters of dip slip, and locally host secondary shear steps on non-mineralized, polished, striated slip planes. Houseknecht and Schenk (2005) inferred approximately $120 \mathrm{~m}$ of stratigraphic separation across the main fault plane, which juxtaposes Seabee (footwall) and Tuluvak (hanging wall) Formations in the upper part of the exposure (fig. 7). Fault orientations in this area in part coincide with the east-dipping normal fault in the 11BG269/11BG270 area.

In addition to the field relations outlined above, well and seismic data provide constraints on the nature of faulting associated with the Umiat anticline. The recognition of repeated stratigraphic intervals in Umiat oil field wells indicate thrust faults at depth (Collins, 1958; Brosgé and Whittington, 1966; Molenaar, 1982; this study). Variability exists among the published seismic interpretations, some of which is undoubtedly related to varying degrees of data quality (see Brosgé and Whittington, 1966; Molenaar, 1982; Kumar and others, 2002; Hanks and others, 2014; Sanders, 2014; this study). Kumar and others (2002) did not pick faults above the lower Brookian (their Fortress Mountain Formation; broadly equivalent to the lower part of our Torok Formation), and Sanders (2014) depicted only one fault cutting the Nanushuk (a subordinate, north-dipping thrust in the anticline's south limb). However, most of the publicly available seismic interpretations include south-dipping thrust faults that ramp up from mid-Torok, cut into the Nanushuk and overlying stratigraphy, and project toward the topographic lineament in the north limb of the anticline. Such interpretations are consistent with our work (sheet 1: cross section A-A'). Structure mapping by Hanks and others (2014) of three-dimensional seismic data yielded a fault pattern similar to the mapped fault pattern of sheet 1 .

\section{Discussion and Summary of Umiat Oil Field Structure}

Geologic mapping of the Umiat anticline's north limb documents a pattern of increasingly younger stratigraphic units to the north. Although this trend in the distribution of map units is predicted in association with a gentle fold in a region of low-relief topography, the uncharacteristically steep bedding dips and truncated or absent stratigraphic units near the lineament support the interpretation that one or more faults cut(s) the north limb of the Umiat anticline in this area. In detail, there is some variability in how the stratigraphy has been mapped near the lineament. Brosgé and Whittington (1966; see also Molenaar, 1982), employing a different stratigraphic nomenclature than later studies, mapped multiple Seabee units in their fault zone, with lowermost Tuluvak (their Ayiyak Member of the Seabee Formation) locally mapped south of the northern margin of the zone; overlying Tuluvak strata (their Tuluvak Tongue of the Prince Creek Formation) are mapped directly north of the fault zone along most of its extent, and Nanushuk lies to the south at Bearpaw Creek and in a small area to the west (compare with sheet 1). Alternatively, Mull and others (2004) and this study approximately map the southern margin of the Brosgé and Whittington (1966) fault zone as a single fault trace with Nanushuk, and in large part Seabee, lying south of the fault and Tuluvak mainly to the north. ${ }^{7}$ Nevertheless, stratigraphic relations across the fault zone of Brosgé and Whittington (1966) are consistent with stratigraphic relations across the single fault trace mapped by Mull and others (2004) and on sheet 1.

The Nanushuk-Tuluvak juxtaposition-with the approximately 400-m-thick Seabee (see below) being locally absent-across the fault/fault zone at Bearpaw Creek (sheet 1) establishes the minimum stratigraphic separation at this locality. Stratigraphic observations of this study and those reported by previous workers seemingly require any fault or fault zone mapped along the lineament to be a south-dip-

${ }^{7}$ This discussion focuses on the main fault of sheet $1 /$ figure 7 and does not explicitly address the smaller-scale and limited extent splay fault that offsets Nanushuk beds by several tens of meters near Bearpaw Creek. 
ping thrust fault or a north-dipping normal fault; setting aside complex, multi-phase deformation scenarios such as an inverted normal fault with less post-inversion dip slip, neither of these scenarios is readily compatible with the north-dipping thrust interpretation of Mull and others (2004). In addition to the surface relations noted, numerous studies of various vintages of seismic data and well logs, including our work, concluded that a south-dipping thrust fault/zone ramps up from the Torok south of the axial surface and cuts into the postTorok stratigraphy in the north limb of the Umiat anticline, projecting toward or breaching near the lineament of figure 7. Ultimately, we do not find this interpretation to be equivocal or controversial, but rather that the available surface and subsurface evidence strongly supports the interpretation of a south-dipping thrust associated with the Umiat oil field as conveyed in cross section $A-A^{\prime}$ (sheet 1 ).

The minor normal faults in the vicinity of 11BG269/11BG270 and the larger normal fault at Umiat Mountain at least in part post-date lithification, as evidenced by mineralized, polished, and stepped shear planes. These faults are thus probably not related to the basinward dipping normal faults and slumps of Houseknecht and Schenk (2005; fig. 3 therein), which are mapped in seismic data and reflect Cretaceous basin-fill architecture and soft-sediment deformation processes (see also Decker, 2007). In fact, the normal faults that we examined may simply represent strain partitioning related to the locally doubly plunging Umiat anticline near Umiat and the larger-scale trend of diminishing structural relief to the east-southeast beyond the Colville River (fig. 5). The faults at 11BG269 and 11BG270 may in part record bedding parallel flexural slip during folding of mechanically rigid successions of Tuluvak. In other words, the normalslip faults of this study may be associated with Paleocene fold-and-thrust belt contraction; additional considerations of along-strike distribution of strain are included below.

\section{Colville River Corridor Structure}

The Colville River in the Umiat region occupies an approximately $3-5-\mathrm{km}$-wide floodplain that maintains a broadly linear, northeastward trend for more than $100 \mathrm{~km}$ from Killik Bend to Shivugak Bluff (fig. 1). This trend, the northeastern part of which lies in the map area, extends obliquely across the structural grain of the foothills fold-and-thrust belt. Quaternary deposits of the floodplain obscure structural relations across the Colville River, and locally excellent bluff exposures rarely occur where there are good outcrops on the opposite bank. Despite somewhat limited outcrop control for detailed correlations of structures across the river, there are indications that structural changes occur at or adjacent to this reach of the Colville River (Brosgé and Whittington, 1966; Mull and others 2004, 2005; this study; see also Detterman and others, 1963). As an example, in the Umiat-Gubik map area, Mull and others (2004) noted that the Fossil Creek anticline becomes more structurally complex approaching the Colville River from the east, and they do not map this anticline northwest of the river (compare to sheet 1). Mull and others (2004) also highlighted the structural complexity of the Umiat anticline at the Umiat oil field and the change to an east-trending axial trace near the Colville River despite the fold's regional southeast trend. These field relations, among others, led Mull and others (2004, 2005) to map a regional-scale, left-lateral strike-slip fault-their Colville fault-along the Colville River floodplain from Killik Bend to beyond Shivugak Bluff (see also footnote 4). Two Colville fault segments were mapped within our study area, with an overlapping left step near the mouth of Prince Creek (Mull and others, 2004). The Colville fault was described as a deepseated wrench fault having no more than a few miles of offset, post-dating and cutting across the early Cenozoic foothills fold-and-thrust belt, and accounting for local structural complexities, deflected axial traces, fold axis terminations, and apparent en-echelon fold patterns.

A Colville River fault has implications for the style of deformation and trap geometries in the foothills petroleum province of the North Slope, but the existence of such a fault remains equivocal. Presented below are new fracture plane data 
collected during this study to address the Colville fault hypothesis.

\section{Fracture Study-Evidence for a Colville Fault?}

The Colville fault is not mapped in outcrop, but many of the Colville River bluff exposures lie within tens of meters to several kilometers of the interpreted trace (Mull and others, 2004, 2005). We measured fracture planes and kinematic indicators, where present, in Colville River corridor outcrops at the Colville incision and Fossil Creek bluff localities as well as at Tattitgak Bluff, Umiat Mountain, and Shivugak Bluff (fig. 1; appendix 2). Our goal in collecting these data was to determine whether outcrop-scale brittle structures in these areas reflect a larger-scale, left-lateral strike-slip fault with a principal displacement zone (PDZ; that is to say, the Colville fault of Mull and others [2004]) lying under the Colville River's broad floodplain.

\section{Premise}

Laboratory models of strike-slip faults deformed in simple shear indicate that subordinate structures form in predictable orientations with respect to a PDZ that accumulates slip parallel to the applied shear direction (see reviews by Christie-Blick and Biddle, 1985; Sylvester, 1988). Figure 8 summarizes orientation and sense of slip relations among structures that may develop in such a strike-slip fault system: 1) strike-slip shear fractures, including Y (synthetic; parallel to PDZ), $\mathrm{R}$ and $\mathrm{P}$ (synthetic), and R' (antithetic; conjugate to R); 2) $\mathrm{T}$ or extension fractures (mode 1 cracks) and normal faults that strike perpendicular to the minimum principal stress; and 3) thrust faults and folds that strike perpendicular to the maximum principal stress. These idealized structures and their orientations are not universally observed in association with strike-slip deformation, with complications arising from the typical heterogeneity of rocks and the commonly protracted, rotational, and cross-cutting nature of strike-slip fault systems (Christie-Blick and Biddle, 1985; Sylvester, 1988). Nevertheless, documenting the presence or absence of subordinate structures is one approach toward better understanding

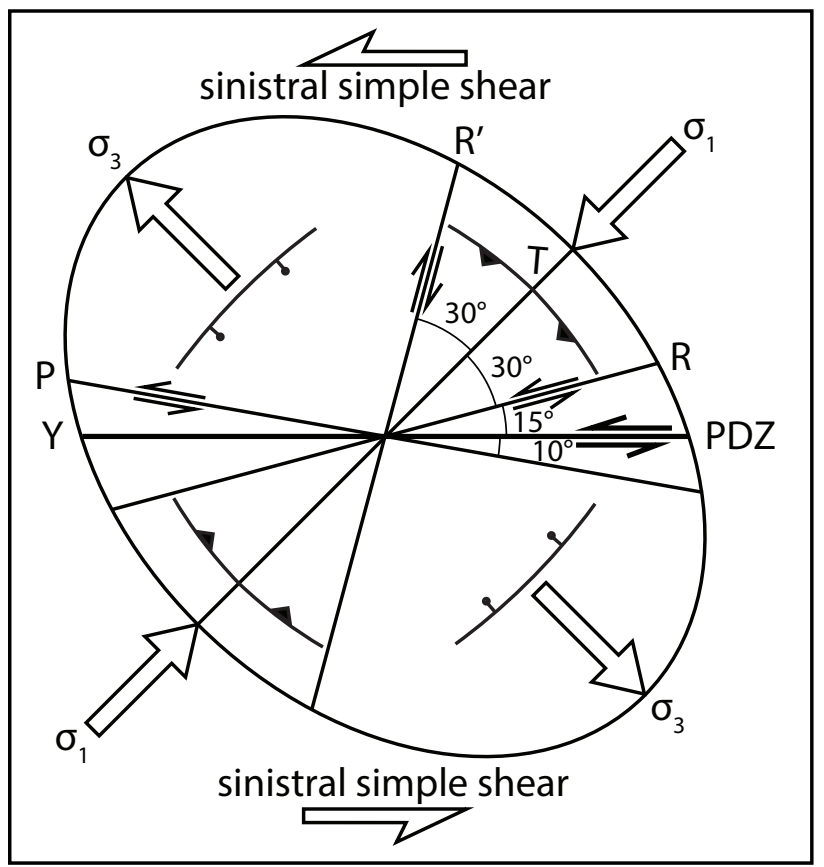

Figure 8. Idealized strain ellipse for left-lateral strike-slip fault system in simple shear. Structures that might form in the noted stress and strain fields are designated. Principal stress axes are oriented $45^{\circ}$ from the principal displacement zone (PDZ). Sigma-1 is the maximum principal stress direction; sigma-3 is the minimum principal stress direction; principle stress arrows depicted here are not quantitative vectors. Figure modified from Christie-Blick and Biddle (1985), Sylvester (1988), and Twiss and Moores (1992); see also McClay (1987).

larger-scale strike-slip faults that may not be directly expressed in outcrop.

Data, Results, and

Strain Ellipse Comparisons

We measured 493 fractures, sampling an approximately $45-\mathrm{km}$-long segment of the Colville River's northeast-trending reach (fig. 9). Most of the fractures ( $n=453$ of 493; 91.9\%) lack shear indicators; the remaining fractures $(n=40$ of 493; 8.1\%) have evidence of shear, but only 23 of these are uniquely constrained kinematically (fig. 10; appendix 2). The Colville incision and Fossil Creek bluff localities each have two fracture sets with relatively low scatter; the Tattitgak and Shivugak Bluffs and Umiat Mountain localities each host numerous fracture sets $(n>2)$ with relatively high scatter and common outliers (fig. 9). There is a clear geographic component to variability in the Colville River bluff fractures data- 


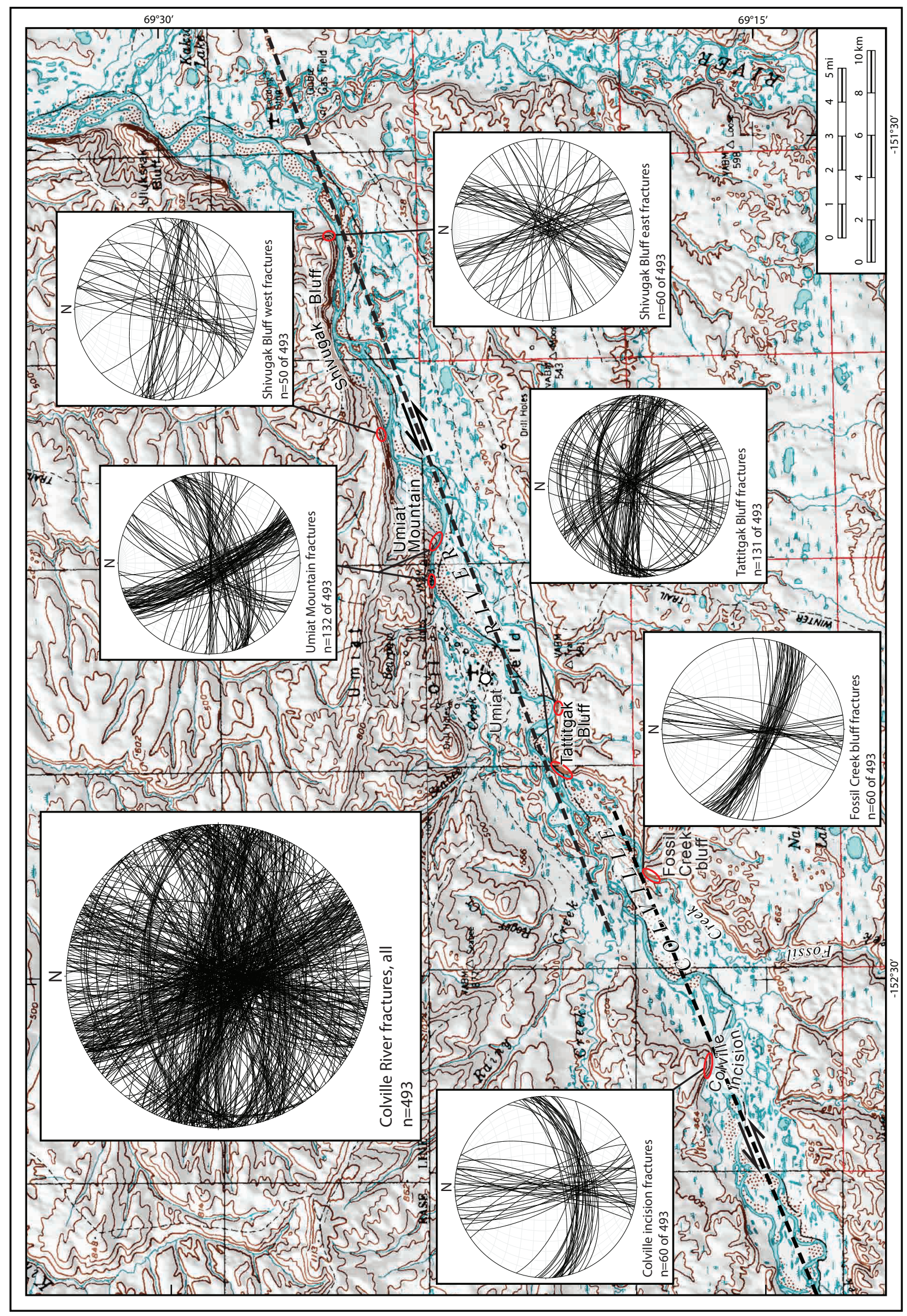

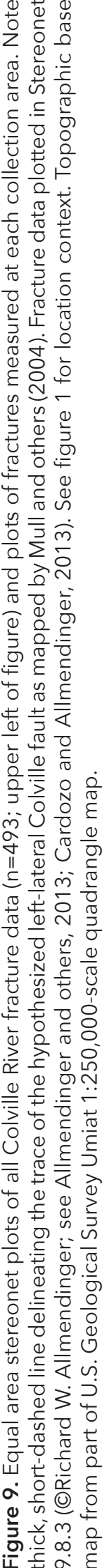




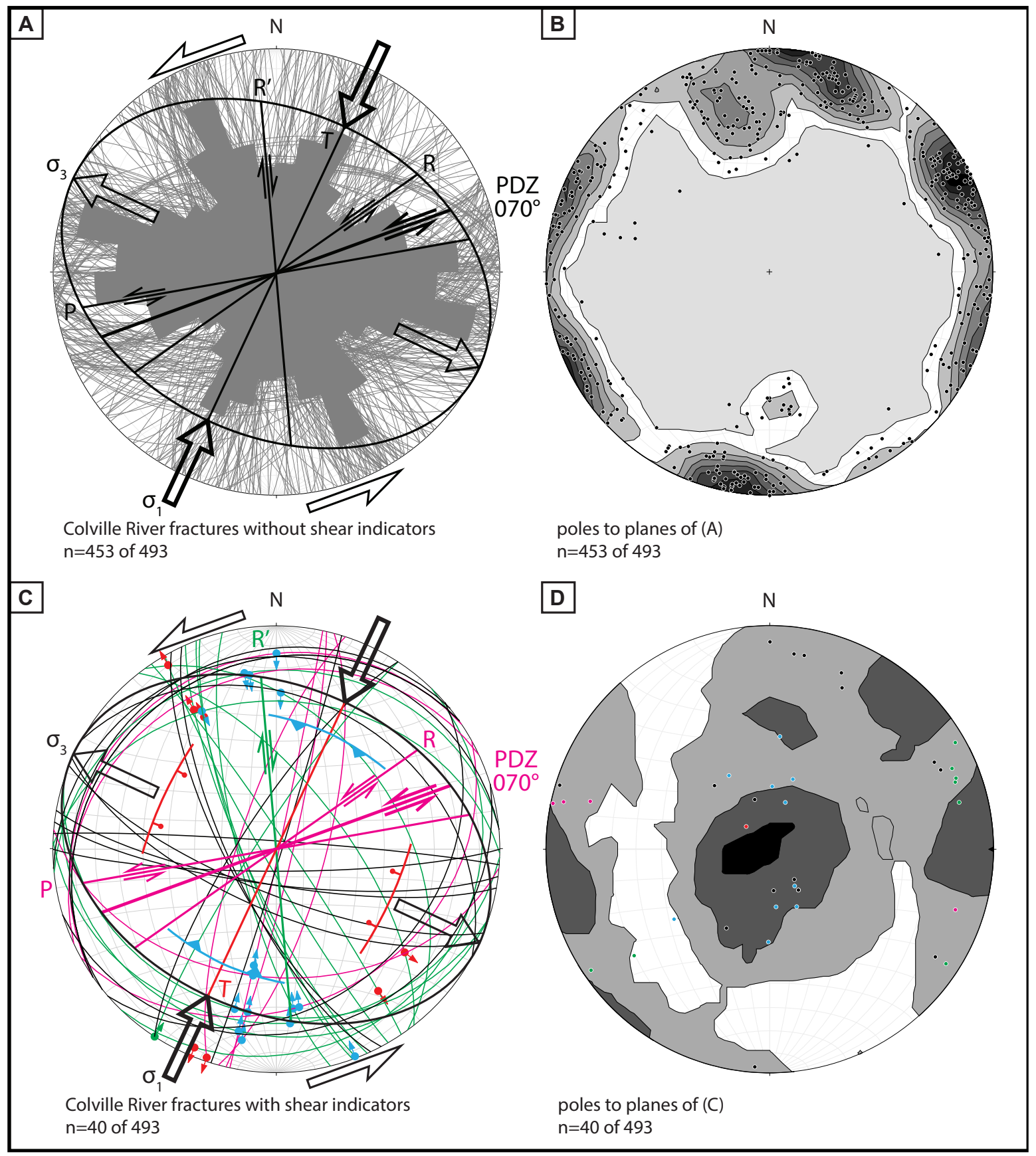

Figure 10. A. Equal area stereonet plot of Colville River fractures that lack indications of shear. Rose diagram strike-orientation petals are bi-directional and scaled to length. See text for discussion of fracture data with respect to the idealized simple shear strain ellipse. B. Poles to planes of A. C. Equal area stereonet plot of Colville River fractures that have indications of shear. Great circles are color-coded to strike component of slip: magenta indicates left lateral and green indicates right lateral. Striae (points along great circles) with hanging wall slip direction (arrows originating on striae) are color-coded to dip component of slip: blue indicates reverse and red indicates normal. Note that one fault has no dip-slip component and the stria and arrow are both color-coded to the strike component of slip. Shear fractures that lack unique kinematic constraints are plotted as black great circles without striae. See text for discussion of fracture data with respect to the idealized strain ellipse. D. Poles to planes of C. Poles are color-coded with principal component of slip as in C. Kamb contours of B and D plotted at intervals of two standard deviations. Fracture data of $A$, B, and D plotted in Stereonet 9.8.3 (see references above); shear fracture data of C plotted in FaultKin 7.4.3 (CRichard W. Allmendinger; see Marrett and Allmendinger [1990] and Allmendinger and others [2013]). See figure 8 and Premise section above for abbreviation explanation and stress arrow descriptions. A spreadsheet of fracture data is presented in appendix 2. 
and there are no wholly repeated fracture set patterns among the stereonet plots of figure 9although there are several fracture sets that occur at more than one locality. In the following evaluation of the fracture data with respect to a simple shear strain ellipse (fig. 8), we employ a PDZ that strikes $070^{\circ}$ (fig. 10), paralleling the northeastern Colville fault segment of Mull and others (2004).

The non-shear fracture dataset (figs. 10A and B) dominantly comprises steeply dipping planes, with the majority of these surfaces dipping greater than $80^{\circ}$; only $10.6 \%(\mathrm{n}=48$ of 453$)$ of these fractures dip less than $60^{\circ}$ and none dip less than $40^{\circ}$ (see fig. 10B). Binning these data in $10^{\circ}$ strike-orientation intervals outlines several prominent fracture orientations, although there are fractures that lie in every one of these bi-directional rose diagram petals. Comparing the visually prominent petals of figure $10 \mathrm{~A}$ with the idealized strain ellipse suggests some possible matches for structures subordinate to the potential PDZ. The strongest correlation is a candidate match for $T$ fractures in the $020-030^{\circ}$ rose petal bin (fig. 10A). T fractures, which are mode 1 cracks, would, by definition, be expected to occur as joints (see Biddle and Christie-Blick, 1985), which is consistent with the non-sheared nature of these fractures. Additional correlations are less clear. There are, at a minimum, candidate fractures for Y (parallel to PDZ) and P shears, but there is a wide spread of the data in this segment of the stereonet (that is to say, $060-090^{\circ}$; fig. 10A) and lack of shear evidence on these fracture planes. Two of the most prominent non-sheared fracture orientations are south-southeast and east-southeaststriking and do not coincide with any predicted orientations of subordinate structures in the idealized strain ellipse (fig. 10A). None of the dominant petals are coincident with the predicted orientations of either synthetic or antithetic Riedel shears (that is to say, R or R').

The shear fracture dataset (figs. 10C and D) comprises a bi-modal distribution of dip magnitudes, with $55.0 \%(\mathrm{n}=22$ of 40$)$ of the planes dipping 66-89 and the remainder dipping less than $45^{\circ}$ (see fig. 10D). There is a wide spread of strike orientations among these data, which include 23 planes with unique kinematic constraints: reverseleft-slip $(\mathrm{n}=7)$; normal-left-slip $(\mathrm{n}=1)$; reverseright-slip $(\mathrm{n}=8)$; normal-right-slip $(\mathrm{n}=6)$; and right-lateral strike-slip $(n=1)$. Comparison of the shear fracture data with the idealized strain ellipse indicates potential correlations (fig. 10C). Three shear fractures strike within $10^{\circ}$ of the predicted maximum principle stress direction $\left(025^{\circ}\right)$ and are consistent with the predicted normal fault orientation (fig. 10C). These three fractures-two of which are not uniquely kinematically constrained and the third being a left-lateral strike-slip fault with only a minor component of normal slipdip steeply $\left(77-88^{\circ}\right)$. Three additional planes with similar strikes also dip steeply but are dominantly strike-slip faults with minor components of reverse slip. There are five shear fractures that strike within $10^{\circ}$ of the predicted minimum principle stress direction $\left(115^{\circ}\right)$ and are thus consistent with the predicted thrust fault orientation (fig. 10C). Two of these fractures dip gently $\left(18^{\circ}\right.$ and $\left.27^{\circ}\right)$ and are dominantly reverse-slip faults, and a third shear fracture lacks unique kinematic constraints but dips a moderate $34^{\circ}$; the remaining two planes also lack unique kinematic constraints and are less ideal candidates for thrust faults due to their steep dips $\left(68^{\circ}\right.$ and $\left.74^{\circ}\right)$. Steeply dipping shear fractures that lie within $10^{\circ}$ of strike of the idealized strikeslip faults include one R' candidate (dominantly strike-slip; minor reverse component of slip) and one $\mathrm{P}$ candidate (not uniquely kinematically constrained); $\mathrm{PDZ} / \mathrm{Y}$ and $\mathrm{R}$ candidates are absent from the shear fracture dataset (fig. 10C).

\section{Additional Considerations and an Alternative Hypothesis for the Fracture Data}

The fracture data presented above and compared to the simple shear strain ellipse of figure 10 include candidate structures that may reflect a regional-scale, left-lateral strike-slip fault striking $070^{\circ}$. However, there are few of these candidate planes, and the most prominent fracture sets, with the exception of possible $T$ fractures, are not accounted for by the simple shear model (fig. 10). This dataset also has relatively few planes with 
shear indicators ( $\mathrm{n}=40$ of 493), and there is evident geographic variability to the fracture orientations, which is consistent with work by Hanks and others (2014). Ultimately, there is a dearth of evidence from the fracture data to infer a large, left-lateral strike-slip fault along the Colville River.

Additional observations and data also bear on an evaluation of the Colville fault hypothesis. Our seismic-based mapping of fold axial traces near the Colville River do not readily permit mapping a through-going, left-lateral strike-slip fault with many miles or kilometers of offset (compare figs. $11 \mathrm{~A}$ and $\mathrm{B}$ ). Although some fold axis trends are seemingly consistent with progressive accumulation of slip along a left-lateral strike-slip fault system at the Colville River, there are problematic aspects to such an interpretation. As an example, the idealized fold axes in the strain ellipses of figure 11 are modeled after progressive deformation of en echelon folds that form and deflect during accumulation of strain in the PDZ. In other words, en echelon fold axes that are genetically tied to strikeslip deformation undergo progressive rotation toward parallelism with the master fault as slip continues to accrue and strike-slip related folding propagates farther from the PDZ (Harding and Lowell, 1979; Sylvester, 1988). No work to date has suggested that the folds in the study area developed in a regional strike-slip regime, so any apparent similarities between deflected, en echelon fold axes associated with strike-slip fault systems may be coincidental.

The fold map pattern of this study (sheet 1 and fig. 11B) may simply reflect fold-and-thrust belt evolution. For example, in our examination of seismic data along the Umiat anticline near the Colville River, disruption of seismic character along an apparently sub-vertical plane and apparent offset of the fold axis suggest right-lateral strike-slip separation across the axial surface at the Colville River (see tear fault(?) of sheet 1). This structure is potentially a tear fault that accrued right-lateral strike-slip offset during detachment folding and associated thrust faulting, with the western part of the fold propagating farther basin- ward and having greater structural relief than the same structural culmination to the east (fig. 5 and sheet 1 ). We do not map the candidate tear fault as extending for more than $5 \mathrm{~km}$ along the Colville River floodplain, although seismic constraints are less robust beyond the fold's axis. This structure may have also partly accommodated the notable change in along-strike structural character of the Umiat anticline across the Colville River, with a north-dipping breaching back-thrust interpreted in seismic data near the East Umiat gas field versus the south-dipping thrust at the Umiat oil field (compare cross sections $\mathrm{A}-\mathrm{A}^{\prime}$ and $\mathrm{B}-\mathrm{B}$ ' of sheet 1). Therefore, deflection of fold axes in the study area may be tied to the distribution of shortening both along strike and across the mechanical stratigraphy, which may locally render tear faults that cut across the regional structural grain but do not extend continuously across the fold-andthrust belt for tens or hundreds of kilometers. Further along-strike strain partitioning related to varying degrees of structural relief may also be accommodated by the normal faults reported and discussed above.

An alternative interpretation of this study's fracture dataset is presented in figure 12, which highlights potential correlations of the measured fractures with respect to a Coulomb-Anderson pure shear model of deformation (for example, see Sylvester, 1988) for the Brooks Range foothills fold-and-thrust belt. The non-shear fracture dataset contains hundreds of steeply dipping planes that strike within approximately $15^{\circ}$ of a hypothetical set of conjugate strike-slip fractures oriented $30^{\circ}$ from a reasonably permissible north-south maximum principle stress direction (figs. 12A and B). Abundant, steeply dipping, east-northeastto east-southeast-striking, non-shear fractures may be associated with folding (see axial planar joints(?) of fig. 12B), and some of the geographic variability of fracture orientations noted above and evident in figure 9 may also reflect fold-related fractures (compare with Twiss and Moores, 1992, p. 48-50). Furthermore, the shear fracture dataset includes dozens of planes with orientations - and in many cases unique slip indicators- 

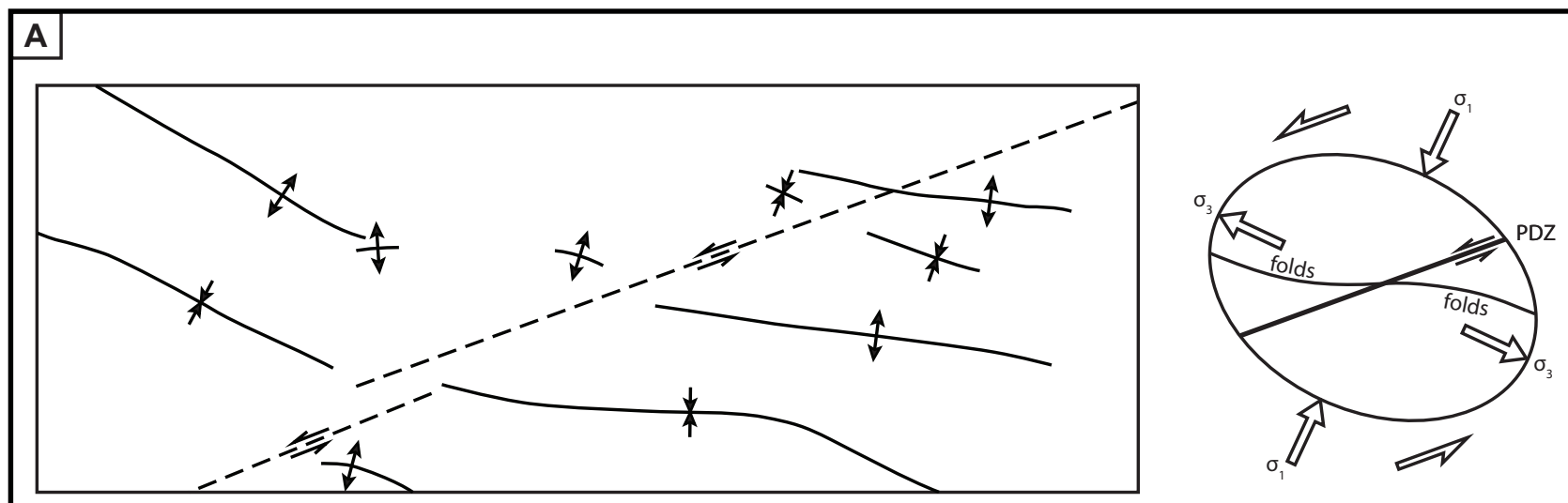

B
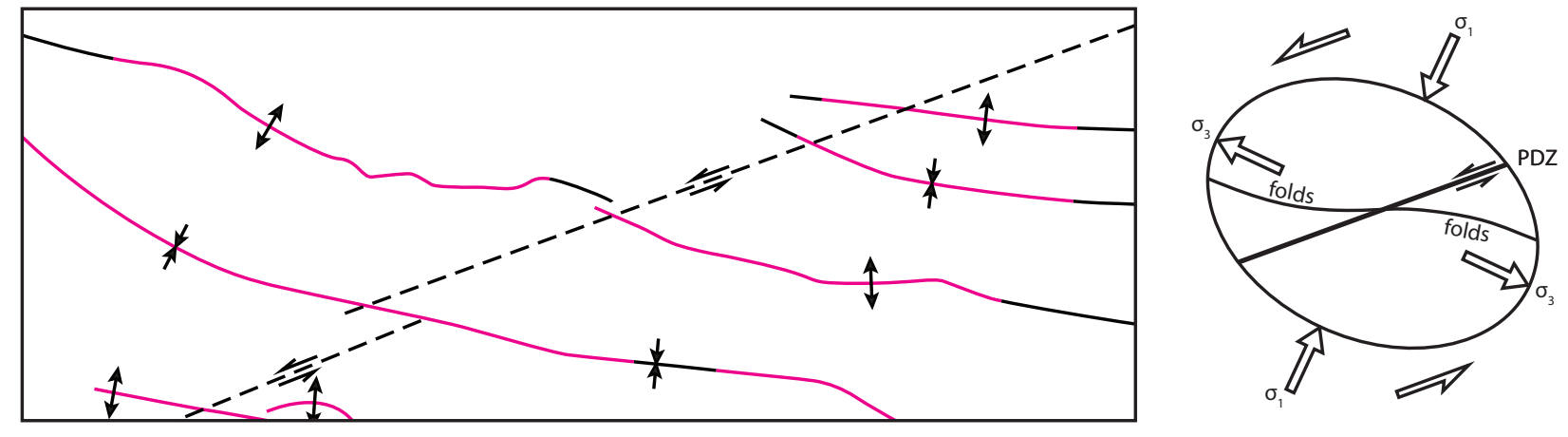

Figure 11. Axial trace line drawings for folds in the Umiat-Gubik map area from Mull and others (2004) (A) and this study (B). Left-lateral strike-slip faults in A and B are the Colville fault of Mull and others (2004), but note that we do not map this fault on sheet 1; see text for discussion. See sheet 1 for map symbol explanation. Strain ellipses at right are modified from Sylvester (1988); see also figure 8 for strain ellipse symbol and abbreviation explanation.

that are consistent with predicted conjugate strikeslip faults and thrust faults (figs. 12C and D). In other words, the $\mathrm{n}=493$ fracture dataset collected to test the Colville fault hypothesis may chiefly reflect strain associated with north-south contraction during the main phase of Paleogene orogenic deformation described above.

Strike-slip faults are commonly difficult to characterize, and the fracture analysis presented here does not rule out the permissibility of regional strike-slip faulting as described by Mull and others (2004, 2005). However, we do not map the Colville fault on sheet 1 due to the lack of compelling surface or subsurface evidence for a through-going, left-lateral strike-slip fault along the Colville River. Furthermore, our fracture-scale to map-scale structural observations are more readily accounted for within the context of pure shear, contractional foldand-thrust belt deformation. Nevertheless, future studies in the central Brooks Range foothills foldand-thrust belt will undoubtedly further constrain the style and timing deformation, the distribution of shortening, and the nature of smaller-scale faulting, all of which have implications for further understanding petroleum systems in this gas-prone region of northern Alaska.

\section{DESCRIPTION AND INTERPRETATION OF MAP UNITS Surficial Deposits}

Quaternary deposits described below are modified from the 1:250,000-scale surficial geologic map of the Umiat Quadrangle (Carter and Galloway, 1986). See also Stevens and others (2003) for derivative geologic mapping along potential access corridors in the Umiat area (see also Reger and others, 2003).

Qal ALLUVIAL DEPOSITS (Quaternary)_Undifferentiated alluvium, 


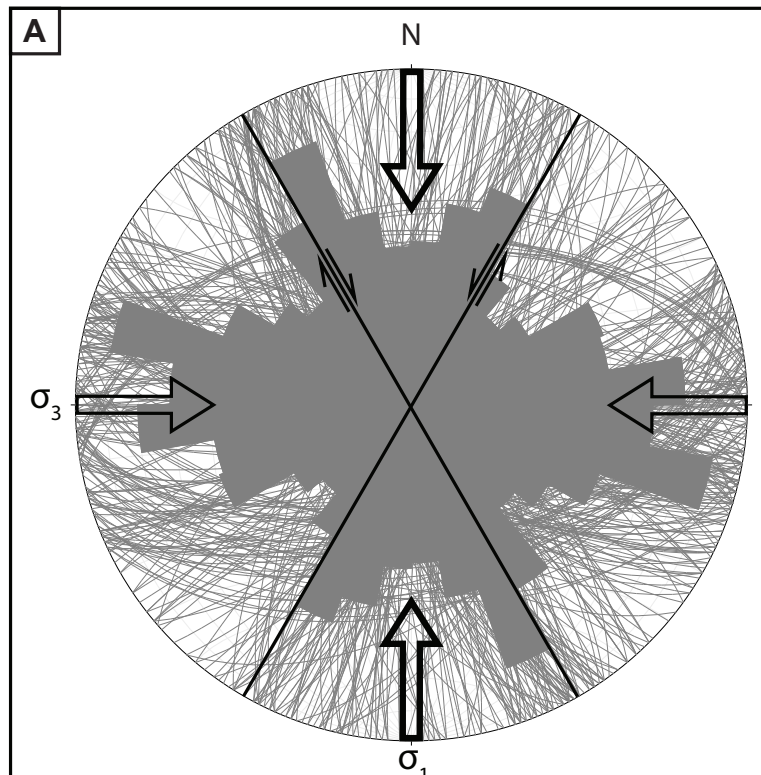

Colville River fractures without shear indicators $n=453$ of 493

C

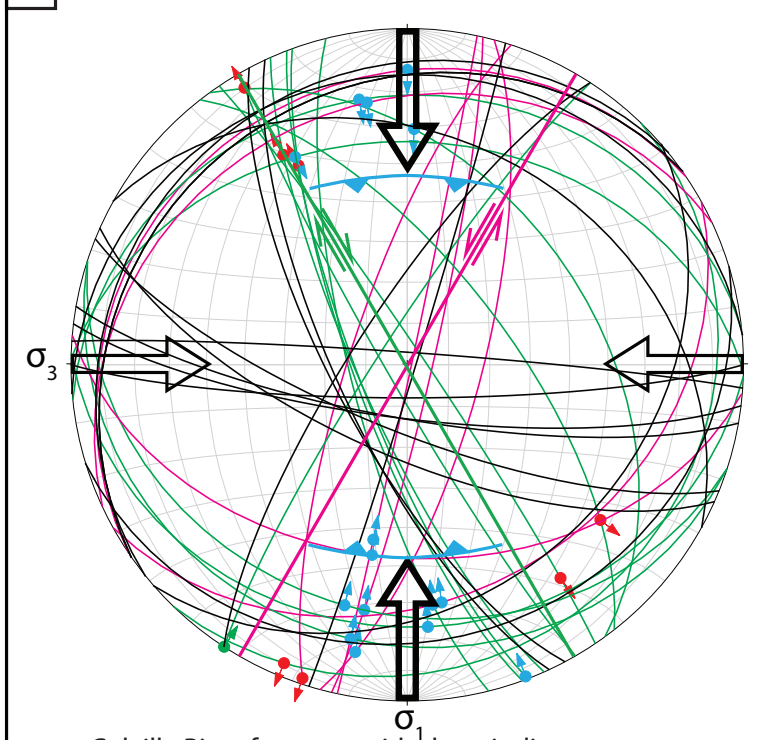

Colville River fractures with shear indicators $\mathrm{n}=40$ of 493

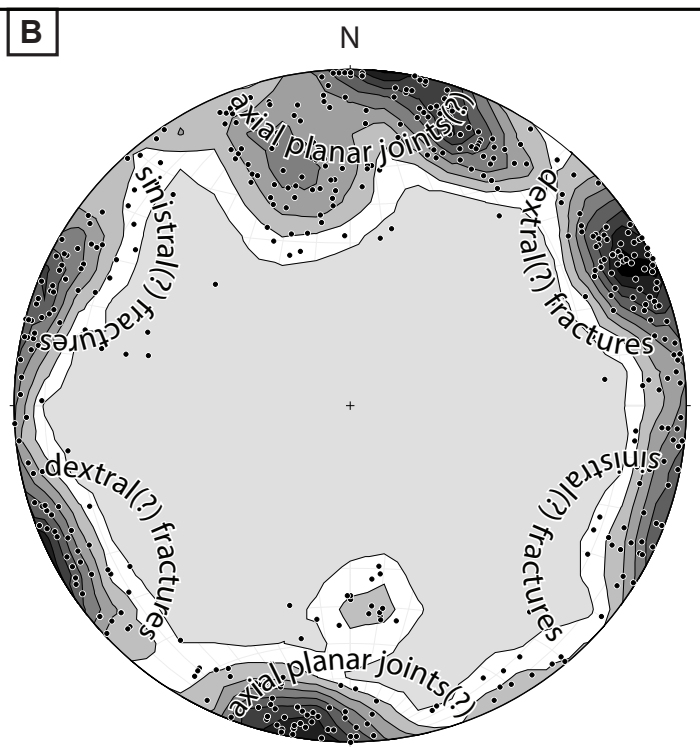

poles to planes of $(A)$ $n=453$ of 493
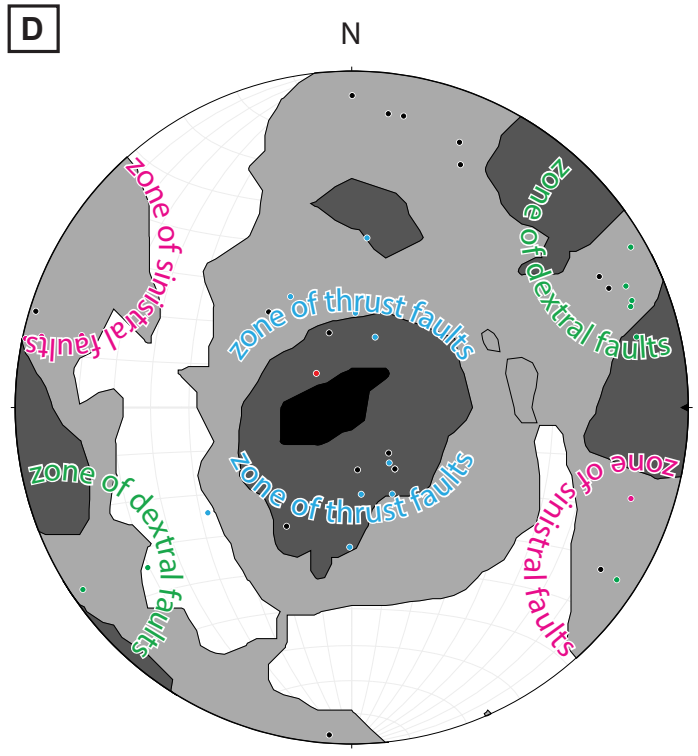

poles to planes of (C) $n=40$ of 493

Figure 12. Stereonet plots of fracture data are the same as presented in figure 10, but here are interpreted within the context of the east-trending central Brooks Range foothills fold-and-thrust belt and a pure shear deformation model. See text for discussion of fracture data with respect to north-south shortening. A. Equal area stereonet plot of Colville River fractures that lack indications of shear. Conjugate strike-slip faults are plotted at $30^{\circ}$ from sigma- 1 , which is oriented north-south. Rose diagram strike-orientation petals are bi-directional and scaled to length. B. Poles to planes of A. C. Equal area stereonet plot of Colville River fractures that have indications of shear. Great circles are color-coded to strike component of slip: magenta indicates left lateral and green indicates right lateral. Striae (points along great circles) with hanging wall slip direction (arrows originating on striae) are color-coded to dip component of slip: blue indicates reverse and red indicates normal. Note that one fault has no dip-slip component and the stria and arrow are both color-coded to the strike component of slip. Shear fractures that lack unique kinematic constraints are plotted as black great circles without striae. D. Poles to planes of C. Poles are color-coded with principal component of slip as in C. Kamb contours of B and D plotted at intervals of two standard deviations. Fracture data of A, B, and D plotted in Stereonet 9.8.3 (see references above); shear fracture data of $C$ plotted in FaultKin 7.4.3 (see references above). Sigma-1 is the maximum principal stress direction; sigma-3 is the minimum principal stress direction; principle stress arrows depicted here are not quantitative vectors. 
including deposits of active and abandoned fluvial channels, as well as floodplains and alluvial terraces up to $8 \mathrm{~m}$ above modern streams. Chiefly comprises stratified deposits of fine- to coarse-grained sand, silty to gravelly sand, and gravel. Modified from Carter and Galloway (1986).

\section{Brookian Megasequence}

The Brookian megasequence (Lerand, 1973; Molenaar, 1983; Hubbard and others, 1987) is the stratigraphic record of Brooks Range orogenesis, with incipient Colville foreland basin sedimentation commencing as early as the Jurassic (Bird and Molenaar, 1992). The foreland basin of what is now the central North Slope was filled during the mid- to Late Cretaceous by a chiefly northeastward prograding siliciclastic wedge, with detritus sourced from the Brooks Range at the basin's southern margin and farther west in the area of the modern Chukchi Sea (Bird and Molenaar, 1992). Portions of three major Brookian depositional cycles occur in the Umiat-Gubik map area: 1) Nanushuk-Torok (Ahlbrandt, 1979; Huffman, 1985; Huffman and others, 1988; Molenaar, 1985, 1988; Houseknecht and Schenk, 2001; Houseknecht and others, 2009; LePain and others, 2009); 2) Tuluvak-Seabee (Mull and others, 2003; Houseknecht and Schenk, 2005; Decker, 2007); and 3) Prince CreekSchrader Bluff-Canning (Molenaar and others, 1987; Mull and others, 2003; Decker, 2007) (fig. 4). All of these formations except the Torok and Canning are recognized in outcrop in the study area (Detterman and others, 1963; Brosgé and Whittington, 1966; Mull and others, 2003, 2004; this study). Deep-water Torok underlies the area and influenced the depositional architecture of overlying units (see below) and the structural evolution of the fold-and-thrust belt (see above). However, deep-water Canning Formation does not occur in the Umiat-Gubik area subsurface, as it was deposited beyond the earliest Schrader Bluff Formation shelf edge established east of the Anaktuvuk River (see below).

The exposed stratigraphy dominantly records shallow-marine, basin-scale topset sedimentation.
Houseknecht and Schenk (2005) also reported that prodelta, seismic-scale Seabee Formation clinoforms prograded across the draped, inherited depositional profile of the Nanushuk shelf; this Seabee clinoform seismic facies is inferred to crop out at Umiat Mountain. Regional stratigraphic work indicates that the topset units of the Umiat area grade basinward into correlative foreset (slope) and bottomset (basin floor) facies (for example, Huffman, 1985; Molenaar, 1988; and Decker, 2007); all of these lithostratigraphic units ultimately condense eastward into the distal Hue Shale (fig. 4). Recent detailed geologic mapping in the Sagavanirktok River (Gillis and others, 2014) and Gilead Creek (Herriott and others, in preparation) areas (fig. 1) further document the proximal-distal stratigraphic relations that developed and evolved through time and space during mid-Cretaceous to Paleogene filling of the Colville foreland basin in the central to east-central North Slope.

\section{Stratigraphic Nomenclature}

The stratigraphic nomenclature of the Colville foreland basin fill succession has undergone major revisions since the pioneering work by Schrader (1902, 1904) and Leffingwell (1919). The Pet-4 program (see above) yielded numerous insights into the stratigraphic framework of the basin (Gryc and others, 1951; Gryc, 1956), rendering a more detailed understanding of the stratigraphy than had previously been established. Subsequent stratigraphic revisions for the region were summarized by Kopf (1970) and Bird (1988b). More recent work by Mull and others (2003), building on decades of detailed stratigraphic studies, presented a markedly revised stratigraphic nomenclature for Cretaceous and Cenozoic units of the central and western Colville basin. This simplified framework aimed to clarify the geologic context of the basin's deposits and to provide more consistently mappable units with regional significance. The current study employs the stratigraphy of Mull and others (2003), with the noted exception that we continue to recognize and map in the Umiat-Gubik area the Schrader Bluff Formation Members-Sentinel Hill, Barrow Trail, and Rogers Creek-in the sense of Detterman and others (1963) and Brosgé and Whittington (1966) 
(see below for further discussion); we retained these members due to their mappability and utility in defining structural map patterns and stratigraphic evolution.

A significant body of literature addressing the geology of the Umiat region predates the stratigraphic revisions by Mull and others (2003). Basic stratigraphic equivalencies relevant to the study area and with respect to the work of Mull and others (2003) include: 1) all former tongues and formations of the Nanushuk Group (abandoned/demoted) are the Nanushuk Formation; 2) the former Colville Group (abandoned) is the non-grouped Seabee, Tuluvak, Schrader Bluff, and Prince Creek Formations; 3) the former Shale Wall Member (abandoned) of the Seabee Formation is the Seabee Formation; 4) the former Ayiyak Member (abandoned) of the Seabee Formation is the lower, marine part of the Tuluvak Formation; 5) the former Tuluvak Tongue (abandoned) of the Prince Creek Formation is the upper, nonmarine part of the Tuluvak Formation; 6) the former Rogers Creek, Barrow Trail, and Sentinel Hill Members (abandoned) of the Schrader Bluff Formation are the undivided Schrader Bluff Formation (see above and below regarding our continued usage of these members); and 7) the former Kogosukruk Tongue (abandoned) of the Prince Creek Formation is the Prince Creek Formation.

PRINCE CREEK FORMATION (regionally Campanian-Paleocene: see review by Mull and others, 2003) (defined and/or locally mapped by Gryc and others, 1951; Whittington, 1956; Detterman and others, 1963; Brosgé and Whittington, 1966; revised by Mull and others, 2003, 2004)_The Prince Creek Formation (fig. 13) comprises nonmarine deposits in chiefly prograding and aggrading depositional systems that were associated with shallow-marine equivalents of the Schrader Bluff Formation (Molenaar, 1983; Mull and others, 2003; Decker, 2007; Flores and others, 2007a, 2007b; van der Kolk and others, 2015) (fig. 4). Van der Kolk and others (2015) generally interpreted the Prince Creek Formation at Shivugak Bluff as comprising distributary and braided fluvial deposits that are progradationally stacked on deltaic strata of the Sentinel Hill Member (Schrader Bluff Formation). Only the older (Upper Cretaceous) part of the Prince Creek crops out in the map area (fig. 4); the best exposures of the unit are mapped at Shivugak and Uluksrak Bluffs (figs. 3B and 13) and along the west bank of the Anaktuvuk River (sheet 1).

The revised Prince Creek Formation (Mull and others, 2003) in the Umiat region is a minimum $552 \mathrm{~m}$ thick as reported by Brosgé and Whittington (1966), who recognized a 96-m-thick tongue of marine rocks along the Uluksrak Bluff trend that they regarded, but did not map, as an upper part of the Sentinel Hill Member. However, documented stratigraphic relations indicate that any intra-Prince Creek marine deposits of the Shivugak and southern Uluksrak Bluffs area would probably lie above the regionally significant mid-Campanian unconformity (MCU) of Decker (2007) (Flores and others, 2007a; van der Kolk and others, 2015). Therefore, any marine succession encased in nonmarine Prince Creek in the Umiat-Gubik area likely correlates to the regional middle Schrader Bluff Formation (in the sense of Decker, 2007) and should not be regarded as an upper part of the Sentinel Hill Member, which is distinctly part of the regional lower Schrader Bluff Formation (see fig. 4 and discussion below). Farther north at the Sentinel Hill Core No. 1 well $(-20 \mathrm{~km}$ north-northeast of Shivugak Bluff) the MCU's location with respect to thick intercalations of nonmarine (Prince Creek) and marine (Schrader Bluff) successions was documented by Flores and others (2007b). Nevertheless, any marine intervals hosted in the Prince Creek Formation of the Colville River area likely record smaller-scale retrogradation during transgressions in the dominantly progradational/aggradational Prince Creek-Schrader Bluff couplet (Mull and others, 2003; Decker, 2007; Flores and others, 2007a, 2007b).

TKpc PRINCE CREEK FORMATION (locally late Campanian-middle-late Maastrichtian: Flores and others, 2007a)Light- to dark-brown- to gray-brown- 

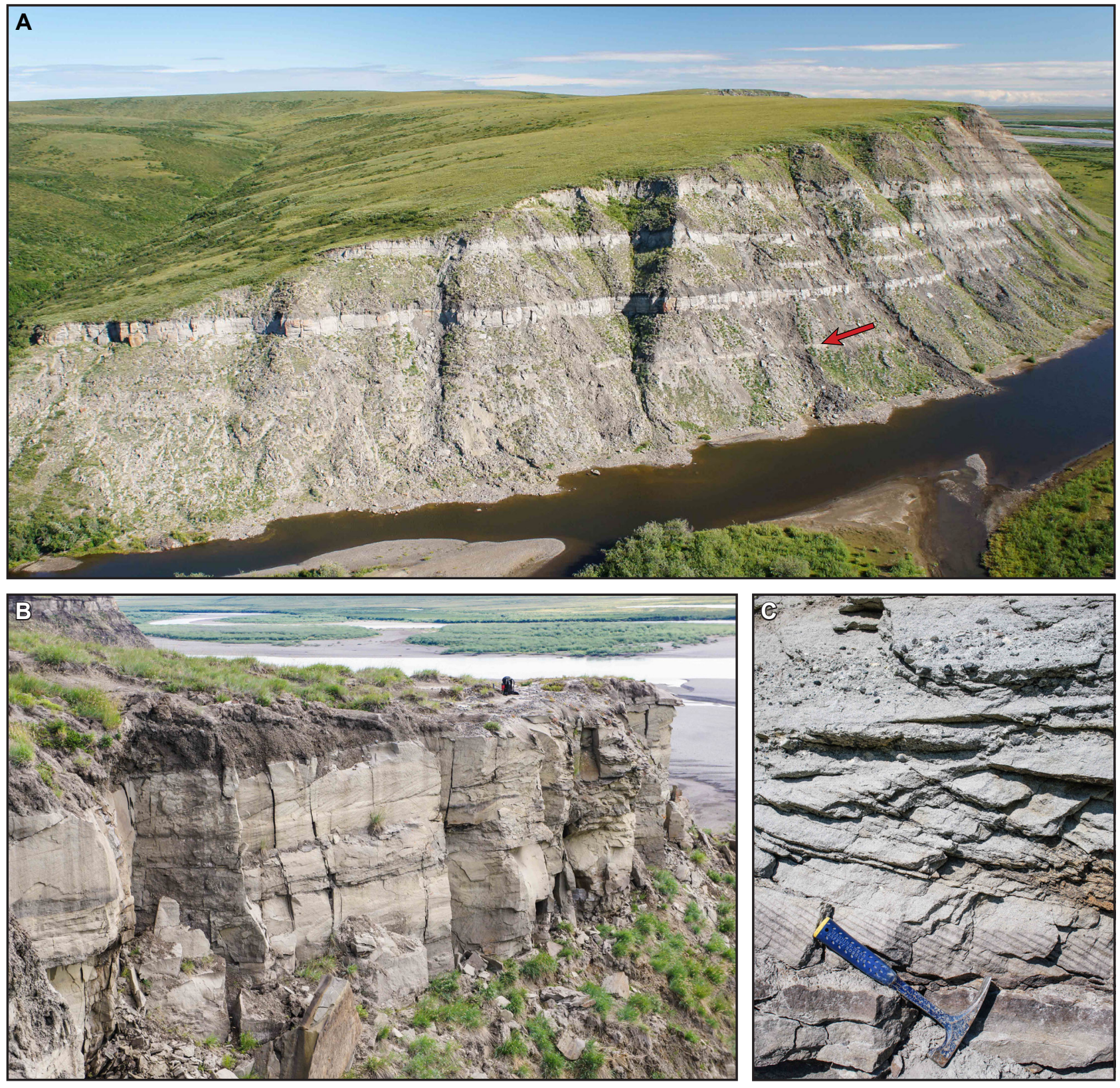

Figure 13. Field photographs of Prince Creek Formation. A. Oblique aerial view northeastward of a thick Prince Creek Formation succession at southwestern end of Uluksrak Bluff. Contact with the underlying Sentinel Hill Member (Schrader Bluff Formation; see red arrow) is consistent with our mapping of Shivugak Bluff. Note repeating stratigraphic motif of thick, erosionally resistant, fluvial sandstone successions, which are locally conglomeratic, that are separated by thicker, less resistant, finer grained, and thinner bedded intervals. The lateral discontinuity of some of the resistant sandstone packages is evident in this $\mathrm{km}$-scale outcrop extent. Topographic relief of bluff at right of photograph is $\sim 90$ $\mathrm{m}$, for sense of scale. B. Outcrop-scale view of fluvial sandstone succession in Prince Creek comparable to resistant packages of A. This $\sim 6$-m-thick cliff-forming section crops out near the top of Shivugak Bluff. Black backpack is $\sim 60 \mathrm{~cm}$ tall. C. Detailed view of cross-stratified sandstone and pebbly sandstone of Prince Creek. This outcrop lies in the north limb of the Gubik anticline between Shivugak and Uluksrak Bluffs. Hammer is $31 \mathrm{~cm}$ long. Photographs by T.M. Herriott.

weathering, dominantly light-gray, thick- to very thick-bedded, moderately indurated, commonly cross-stratified (foreset amplitudes to greater than $1 \mathrm{~m}$ ), quartzose pebbly sandstone, fine- to coarse-grained sandstone, and conglomeratic lag deposits, with subordinate gray to dark-gray, chiefly thin- to medium-bedded, carbonaceous 
to bentonitic very fine-grained sandstone and mudstone, as well as medium- to very thick- bedded, dull to bright-and-dullbanded lignitic to subbituminous coal. The cross-stratified sandstone and pebbly sandstone lithofacies have scoured, sharp basal contacts and cm-scale, coalified woody debris is commonly observed; pebbles (commonly $1.5 \mathrm{~cm}$ long-axis dimension) are subangular to subrounded and generally comprise vein quartz and cherty argillite; both the pebble and sand fractions exhibit salt-and-pepper-like compositional coloring. Very fine-grained sandstone and mudstone facies are commonly rusty-orange- to tannish-yellow-weathering, and root traces are locally observed.

\section{SCHRADER BLUFF FORMATION} (regionally Santonian-Maastrichtian: see review by Mull and others, 2003; as young as Paleocene(?): see Decker, 2007) (defined and/or locally mapped by Gryc and others, 1951; Whittington, 1956; Detterman and others, 1963; Brosgé and Whittington, 1966; revised by Mull and others, 2003, 2004) — The Schrader Bluff Formation comprises the record of shallow-marine depositional systems that interfingered with nonmarine Prince Creek Formation along transgressive-regressive paleoshorelines, principally rendering progradational and aggradational topsets of this basin-scale depositional cycle (Molenaar, 1983; Mull and others, 2003; Decker, 2007; Flores and others, 2007a, 2007b; van der Kolk and others, 2015) (fig. 4). The base of the Schrader Buff Formation transgressively overlies the Tuluvak Formation. Van der Kolk and others (2015) described the upper part of the Schrader Bluff Formation (Sentinel Hill Member) at Shivugak Bluff as comprising muddy, river-dominated deltaic strata. Following Detterman and others (1963), Brosgé and Whittington (1966), and the criteria described by Mull and others (2003), we map the upper contact of the Schrader Bluff at the onset of nonmarine sedimentation of Prince Creek.

Early detailed studies of the Schrader Bluff Formation were by Gryc and others (1951), with subsequent work in the Umiat region leading to the definition of three members, in descending order: Sentinel Hill (fig. 14), Barrow Trail (fig. 15), and Rogers Creek (fig. 16) (Whittington, 1956; Detterman, 1956a; Detterman and others, 1963; Brosgé and Whittington, 1966). However, in a regional context, these membersincluding the formation's type section along the east bank of the Anaktuvuk River at Schrader Bluff (fig. 1) - constitute only the lower of three regional parts in the formation (fig. 4). This lower part of the Schrader Bluff comprises mid-Campanian and older (Santonian) strata that occur entirely beneath the MCU, whereas the two upper parts of the Schrader Bluff Formation, which are separated by a transgressive surface, lie above the MCU (Decker, 2007; fig. 4).

Decker (2007) established a sequence-stratigraphic framework for the Schrader Bluff Formation by principally examining regional subsurface datasets. In light of this work, it became evident that the locally applied informal subdivisions of lower, middle, and upper parts for the Schrader Bluff Formation as proposed and applied by Mull and others $(2003,2004,2005)$ do not convey the regional complexity of the formation. Subsequent mapping by Gillis and others (2014), Herriott and others (in preparation), and this study reserve usage of the terms lower, middle, and upper Schrader Bluff Formation to refer to the regional, sequence stratigraphically significant subdivisions of the Schrader Bluff Formation in the sense of Decker (2007). Within this context, we retain the Rogers Creek, Barrow Trail, and Sentinel Hill Members, which are now recognized as the regional lower part of the Schrader Bluff Formation; these members do not occur in outcrop east of the Anaktuvuk River, mainly reflecting basinward facies changes from shelfal Schrader Bluff Formation to deep-water Canning Formation and Hue Shale equivalents that were incised during establishment of the MCU (Decker, 2007). We do not recognize middle or upper Schrader Bluff Formation in the study area. Our intention in re-introducing the older member nomenclature of Detterman and others (1963) and Brosgé and Whittington (1966) for the (lower) 

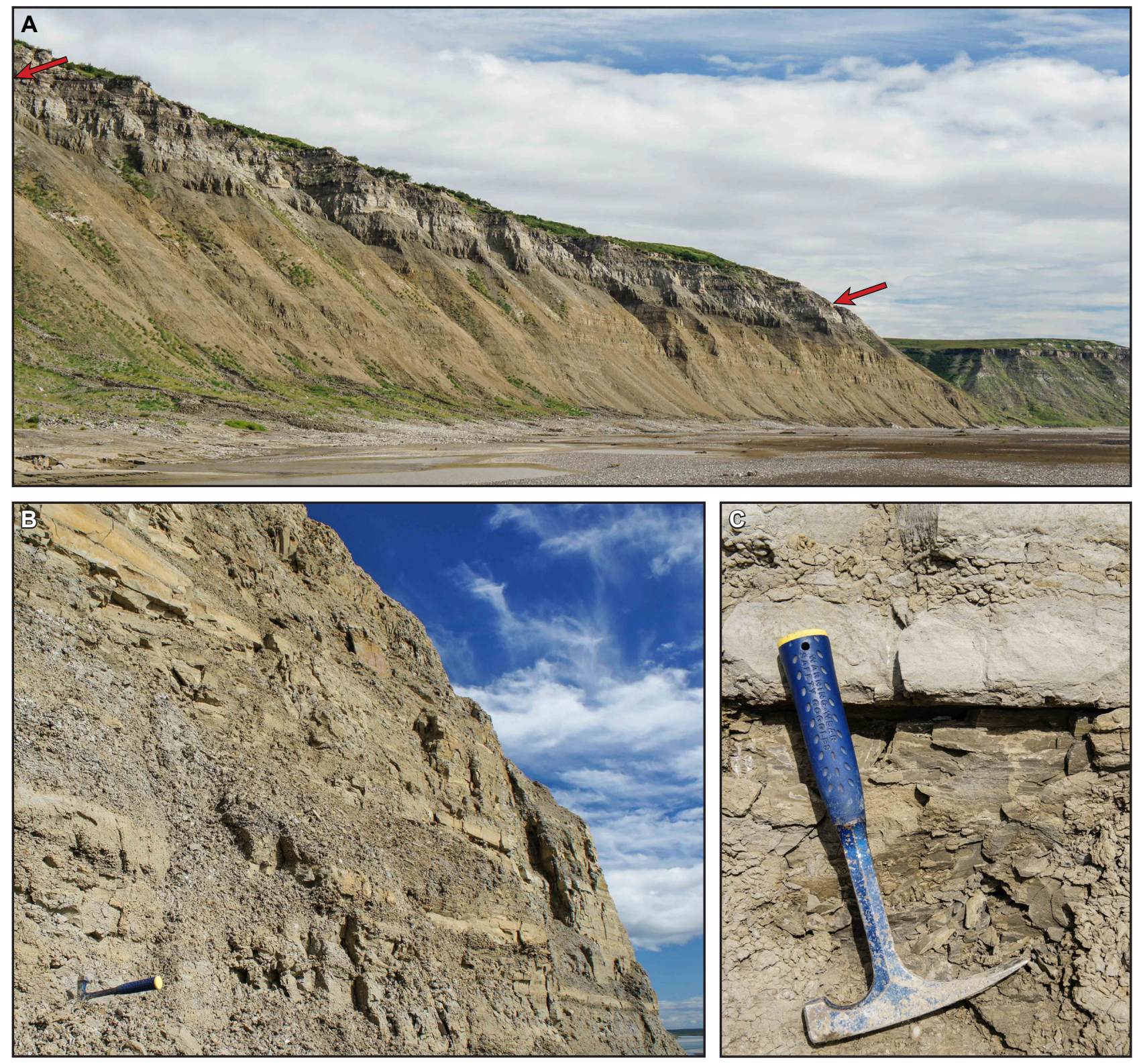

Figure 14. Field photographs of Sentinel Hill Member, Schrader Bluff Formation, at Shivugak Bluff. A. View east-northeastward of dominantly Sentinel Hill along west-central part of Shivugak Bluff. See Sentinel Hill Member-Prince Creek Formation contact at red arrows. Topographic relief of bluff is $\sim 120 \mathrm{~m}$, for sense of scale. B. Good outcrop expression of thin bedded, Sentinel Hill mudstone and subordinate sandstone that is common to the member but generally renders a recessive weathering profile for the unit. Hammer is $31 \mathrm{~cm}$ long. C. Detailed view of intercalated mudstone and sandstone of Sentinel Hill. Hammer is $31 \mathrm{~cm}$ long. Photographs by T.M. Herriott.

Schrader Bluff Formation of the Umiat-Gubik area is to clearly communicate current understanding of Schrader Bluff Formation stratigraphy.

Detterman and others (1963) reported a 572-m-thick Schrader Bluff Formation along the Chandler River at Tuluvak Bluffs (fig. 1) directly south of the study area. However, approximately $25 \mathrm{~km}$ to the north at Shivugak Bluff and the
Gubik gas field the Schrader Bluff Formation is thinner at $474 \mathrm{~m}$ thick (Brosgé and Whittington, 1966). An even thinner, approximately 320-mthick Schrader Bluff Formation is identified in the Tulaga 1 well (Decker, 2007), which lies approximately $35 \mathrm{~km}$ north-northeast of the Shivugak Bluff/Gubik gas field area. These thicknesses indicate a marked northward thinning of the lower 

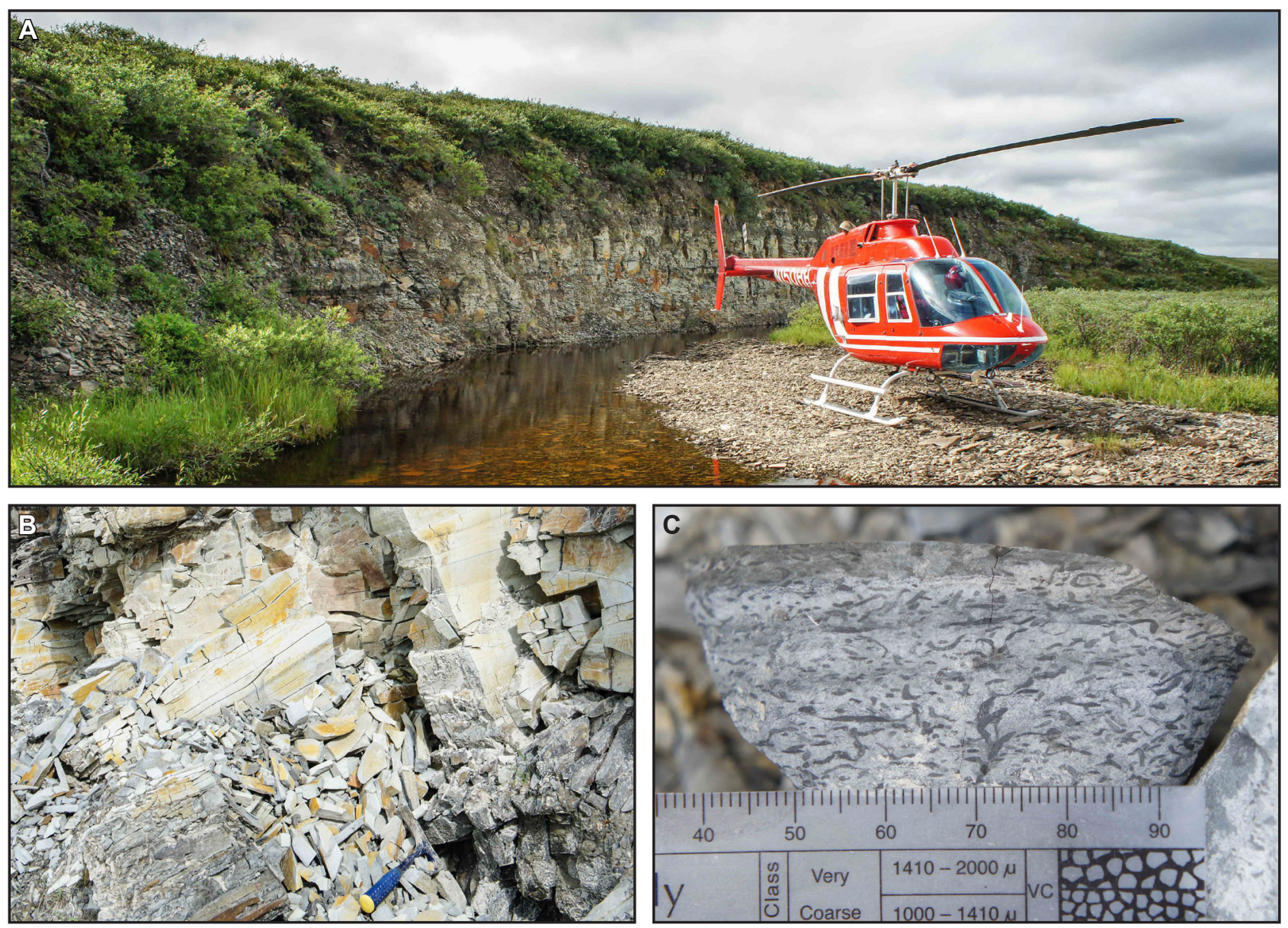

Figure 15. Field photographs of Barrow Trail Member, Schrader Bluff Formation. A. Small cutbank exposure of Barrow Trail along an unnamed tributary near the headwaters of Kogosukruk River. This resistant, silicified, thin- to medium-bedded sandstone and siltstone succession is typical of the Barrow Trail (see also fig. 3C). This outcrop lies $\sim 1 \mathrm{~km}$ north of the map area. B. Blocky to hackly weathering of silicified deposits are common in the unit, and likely reflects a tuffaceous component to these strata. This outcrop is near the mouth of Fossil Creek. Hammer is $31 \mathrm{~cm}$ long. C. Detailed view of Phycosiphon in very fine-grained sandstone. This trace fossil is abundant in Barrow Trail, and is also common in the overlying Sentinel Hill. Phycosiphon may constitute the "dark-gray spindle(s)" described by Detterman and others (1963). Rock fragment is from outcrop of figure 3C. Scale in mm. Photographs by T.M. Herriott.

Schrader Bluff Formation, which is reflected on cross section B-B' (sheet 1). A similar pattern and comparable degree of northward thinning of the lower Schrader Bluff stratigraphy is also evident in our examination of an approximately 60-km-long, north-trending seismic line in the Anaktuvuk River area east and northeast of the study area. Future investigations may determine what basin-scale factors controlled this northward thinning trend. Hypotheses that may be tested include 1) whether Santonian-Campanian accommodation increased south of the Barrow arch toward the basin axis as a function of continued compaction of Torok clinoforms; 2) whether a northward decreasing sandstone:shale ratio may have rendered a thinner lower Schrader Bluff succession to the north that would also have been subjected to greater compaction during burial; and/or 3) whether foreland basin flexural subsidence continued during the Late Cretaceous.

Note that the Schrader Bluff members described below typically express a predictable weathering profile, with Rogers Creek and Sentinel Hill Members generally being recessive, muddier units that underlie and overlie, respectively, the commonly more resistant, sandier Barrow Trail Member. 



Figure 16. Field photographs of Rogers Creek Member, Schrader Bluff Formation. A. Oblique aerial view northwestward of Rogers Creek strata cropping out at the southwestern end of Shivugak Bluff. Contact with overlying Barrow Trail Member marked by the red arrow. Topographic relief of bluff near center of photograph is $\sim 70 \mathrm{~m}$, for sense of scale. Photograph by T.M. Herriott. B. The bentonitic, typically fine-grained Rogers Creek forms very few outcrops in the map area, with several small exposures in the Prince Creek drainage (this photograph and C). Note poorly indurated, hackly fracturing character of this generally recessive unit. Pistachio green bentonites (above hammer) are locally observed. Hammer is $\sim 30 \mathrm{~cm}$ long. Photograph by D.J. Mauel. C. View of well indurated, very fine-grained Rogers Creek sandstone with discrete, light-gray trace fossils (Planolites[?]). Specimen is from same locality as B. Hammer for sense of scale. Photograph by D.J. Mauel.

Ksbls SCHRADER BLUFF FORMATION, REGIONAL LOWER PART, SENTINEL HILL MEMBER (middle Santonian-early Campanian: Jones and Gryc, 1960; Detterman and others, 1963; Brosgé and Whittington, 1966) (mapped in the sense of Detterman and others, 1963; Brosgé and Whittington, 1966)—Brown to light- to dark-gray, locally distinctly brown- and brown-purple-weathering, chiefly thin-bedded, moderately to poorly indurated, tuffaceous to locally siliceous, faintly ripple cross-laminated to wispy, disrupted, or convolute laminated mudstone and very fine-grained sandstone, with subordinate light-gray- to brown-purple-weathering, plane-laminated to ripple cross-laminated to locally trough cross-stratified, very finegrained sandstone in amalgamated bedsets to $10 \mathrm{~m}$ thick. Recessive intervals are common, comprising "popcorn"-weathering, light- to dark-gray, bentonitic claystone and yellow-green to pistachio-lime-colored bentonite. Amalgamated sandstone lithofacies contains thin lag deposits of intra-formational mudstone rip-up clast conglomerates, with laminae defined by carbonaceous debris and rhizoliths locally observed. Trace fossil assemblage commonly includes Schaubcylindrichnus, Paleophycos, and locally densely 
packed Phycosiphon. Shell fragments from large Sphenoceramus are locally observed. Member is $119 \mathrm{~m}$ thick near Shivugak Bluff (Brosgé and Whittington, 1966).

Ksblb SCHRADER BLUFF FORMATION, REGIONAL LOWER PART, BARROW TRAIL MEMBER (middle Santonian-early Campanian: Jones and Gryc, 1960; Detterman and others, 1963; Brosgé and Whittington, 1966) (mapped in the sense of Detterman and others, 1963; Brosgé and Whittington, 1966)_Light-gray to tan to brown, thin- to medium-bedded, typically well indurated, locally friable, low-angle wavy, trough, hummocky, and swaley cross-stratified, locally argillaceous, locally carbonaceous and woody debris-bearing, tuffaceous, erosionally resistant very fine- to fine-grained sandstone, with subordinate gray, medium- to thick-bedded, carbonaceous mudstone, dark-gray to black, thin-bedded, siliceous tuff, and chocolate-brown to olive-green, medium-bedded, "popcorn"-weathering bentonitic tuff. Sandstone beds are locally ripple cross-laminated and locally exhibit sharp, scoured bases with up to $80 \mathrm{~cm}$ of erosional relief. Siderite nodule, sandstone rip-up clast, and extra-basinal clast conglomerates occur as thin lag deposits. Sandstone and mudstone beds are locally bioturbated, and discrete trace fossils include Macaronichnus, Asterosoma, and Schaubcylindrichnus; a medium- to darkgray, hackly weathering, well indurated very fine-sandstone and mudstone lithofacies distinctly occurs in this unit and is commonly intensely bioturbated by Phycosiphon. Prismatic calcite detritus, likely from Inoceramus shells, is locally abundant, as are partially preserved Sphenoceramus specimens. Member is $175 \mathrm{~m}$ thick at Shivugak Bluff (Brosgé and Whittington, 1966).
Ksblr SCHRADER BLUFF FORMATION, REGIONAL LOWER PART, ROGERS CREEK MEMBER (middle Santonian-early Campanian: Jones and Gryc, 1960; Detterman and others, 1963; Brosgé and Whittington, 1966) (mapped in the sense of Detterman and others, 1963; Brosgé and Whittington, 1966)_Light- to dark-gray to olive-brown, thinto medium-bedded, typically poorly indurated, tuffaceous to bentonitic, ripple cross-laminated to structureless siltstone and mudstone, with subordinate lightgray- to light-tan-weathering, locally thick-bedded, tuffaceous, ripple cross-laminated, locally well developed hummocky and swaley cross-stratified, coarsening and thickening upward packages of very fineto fine-grained sandstone. Distinctive light-yellow- to white-weathering, very well indurated, siliceous tuff beds locally observed, as are rare, buff-weathering, very well indurated limestone beds with a probable siliciclastic constituent. Recessive intervals are common and inferred to contain abundant bentonite based on "popcorn"-weathering of colluvium. Skolithos traces and Sphenoceramus body fossils are observed in the sandstone facies. Member is 178-181 m thick in Gubik Test Nos. 1 and 2 (Robinson, 1958; Brosgé and Whittington, 1966).

TULUVAK FORMATION (regionally Turonian-Coniacian: see review by Mull and others, 2003; potentially as old as Cenomanian: Shimer and others, 2016) (defined and/or locally mapped by Gryc and others, 1951; Whittington, 1956; Detterman and others, 1963; Brosgé and Whittington, 1966; revised by Mull and others, 2003)_The Tuluvak Formation (fig. 17) is a regionally regressive, locally very coarse-grained nonmarine and shallow-marine (nearshore) sandstone and conglomerate unit correlative with principally offshore to deep-water facies of Seabee Formation (Houseknecht and Schenk, 2005; Decker, 2007) (fig. 4). Mull and others (2003) 
reported that the most basinward outcrops of the Tuluvak are in the Umiat (Mull and others, 2004) and Chandler Lake (Kelley, 1990) Quadrangles and suggested that the terminal shelf margin of the Tuluvak-Seabee depositional cycle may lie in the western Sagavanirktok Quadrangle ( $>40 \mathrm{~km}$ east of study area). Houseknecht and Schenk (2005) interpreted the lower Tuluvak at the eastern extent of Umiat Mountain as chiefly recording progradational delta front and channel associated processes; this locality is the best exposure in the map area to examine Tuluvak (fig. 17). The revised Tuluvak Formation (see Mull and others, 2003) in the Umiat-Gubik area is approximately $285 \mathrm{~m}$ thick (Robinson; 1958; Molenaar, 1982) and serves as the primary reservoir of natural gas at the Gubik field (see above). Tuluvak sandstones near the summit of Umiat Mountain emit a slight, ephemeral hydrocarbon odor.
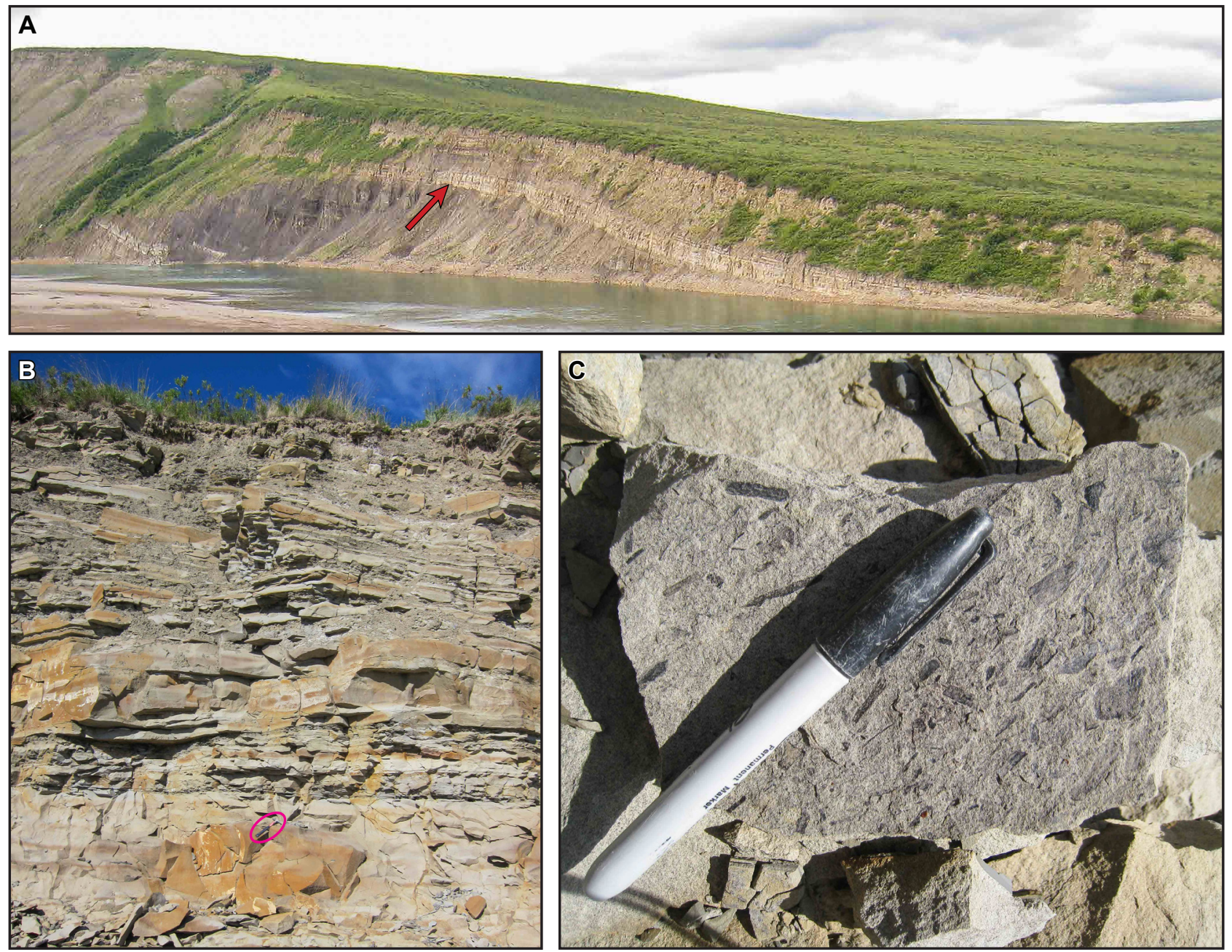

Figure 17. Field photographs of Tuluvak Formation at Umiat Mountain. A. Oblique aerial view northwestward of erosionally resistant Tuluvak overlying generally recessive Seabee Formation, with the Colville River in the foreground; the Seabee-Tuluvak contact is marked by the red arrow. Stark juxtaposition of disparate Seabee facies in outcrop below the heavily vegetated draw at left of photograph delineates the normal fault mapped on sheet 1 (see also Houseknecht and Schenk, 2005). The Umiat Mountain summit lies at the leftmost skyline, $\sim 185 \mathrm{~m}$ above the river, for sense of scale. Photograph by M.A. Wartes. B. Tabular, very thick- to thin-bedded, graded sandstones at the base of Tuluvak immediately above river level in A. Hammer is $\sim 30 \mathrm{~cm}$ long (see magenta outline). Photograph by R.J. Gillis. C. Detailed character of salt-and-pepper colored sandstone in float near the lower Tuluvak. This bedding plane hosts abundant $\mathrm{cm}$-scale coalified plant fragments, which are locally common in Tuluvak. Marker is $14 \mathrm{~cm}$ long. Photograph by M.A. Wartes. 
Ktu TULUVAK FORMATION (locally Turonian-Coniacian: Jones and Gryc, 1960; Detterman and others, 1963; Brosgé and Whittington, 1966; potentially as old as Cenomanian: Shimer and others, 2016)_-Tan- to brown- to orange-brown-weathering, medium-gray to medium-brown, chiefly thin- to medium-bedded, commonly normally graded, well indurated, moderately-sorted, lithicand locally quartz-rich, locally carbonaceous (including coalified woody debris), erosionally resistant very fine- to medium-grained sandstone, with subordinate thin-bedded, plane-parallel laminated mudstone. Sandstone grains are subrounded to subangular. Mudstone rip-up clasts and siderite nodules as clasts are locally observed in sandstone beds, as are symmetrical ripples and low angle cross-stratification.

SEABEE FORMATION (regionally Cenomanian-Coniacian: Gryc and Jones, 1960; Lanphere and Tailleur, 1983; see review by Mull and others, 2003; see also Shimer and others, 2016) (defined and/or locally mapped by Gryc and others, 1951; Whittington, 1956; Detterman and others, 1963; Brosgé and Whittington, 1966; revised by Mull and others, 2003, 2004)_-The Seabee Formation (fig. 18) principally consists of transgressive and regressive offshore to deep-marine strata of the Tuluvak-Seabee depositional cycle (Houseknecht and Schenk, 2005; Decker, 2007) (fig. 4). The lower Seabee Formation in the Umiat-Gubik and surrounding areas comprises deposits that draped the relict, broad Nanushuk shelf during a major transgression that terminated Nanushuk-Torok deposition (Molenaar, 1985, 1988; Bird and Molenaar, 1992; Houseknecht and Schenk, 2005; Decker, 2007; Houseknecht and others, 2009; LePain and others, 2009); this transgression resulted in a regional-scale westward shift of the paleoshoreline to hundreds of kilometers west of Umiat (Houseknecht and Schenk, 2005; Decker, 2007). The basal Seabee transgressive succession is overlain by shelf-perched, prodel- ta-associated Seabee clinoforms that prograded basinward of coeval nearshore and nonmarine strata of the Tuluvak Formation with an ultimate shelf margin established east of the mapped area (Houseknecht and Schenk, 2005; see reference and below for additional, higher-frequency sequence-stratigraphic relations within Seabee). The inherited shelf-slope-basin floor profile strongly influenced the stratigraphic architecture of the Seabee Formation, yielding lower-relief (hundreds of feet) prodelta Seabee clinoforms above the Nanushuk paleoshelf and higher-relief (thousands of feet) slope clinoforms to the east of the terminal Nanushuk-Torok shelf margin that lies approximately $20 \mathrm{~km}$ east of the study area (Houseknecht and Schenk, 2005; Decker, 2007; see below).

Houseknecht and Schenk (2005) provided a sequence-stratigraphic framework for the upper Nanushuk-Seabee-lower Tuluvak stratigraphy at Umiat Mountain, interpreting distal offshore environments for the bulk of Seabee, although an intra-Seabee lowstand systems tract notably hosts a 37-m-thick sandy shoreface succession encased in hundreds of meters of transgressive and highstand bentonitic mudstone. Reported thicknesses for the revised Seabee Formation (Mull and others, 2003) range from 365-440 $\mathrm{m}$ in the Umiat-Gubik area (Collins, 1958; Robinson, 1958; Molenaar, 1982), but the unit regionally thickens markedly basinward as noted above. The south face of Umiat Mountain includes an oil-stained outcrop of Seabee sandstone (Houseknecht and Schenk, 2005) and is the only locality in the map area where the formation is well exposed (figs. 17A and 18).

Ks

SEABEE FORMATION (locally Cenomanian-Turonian: Jones and Gryc, 1960; Lanphere and Tailleur, 1983; Shimer and others, 2016)_-Tan-gray- to medium-gray-weathering, medium- to darkgray, thin-bedded, dominantly poorly indurated, tuffaceous to bentonitic, locally fissile, plane-parallel laminated to rippled siltstone, mudstone, shale, and claystone, with subordinate tan-gray-weath- 

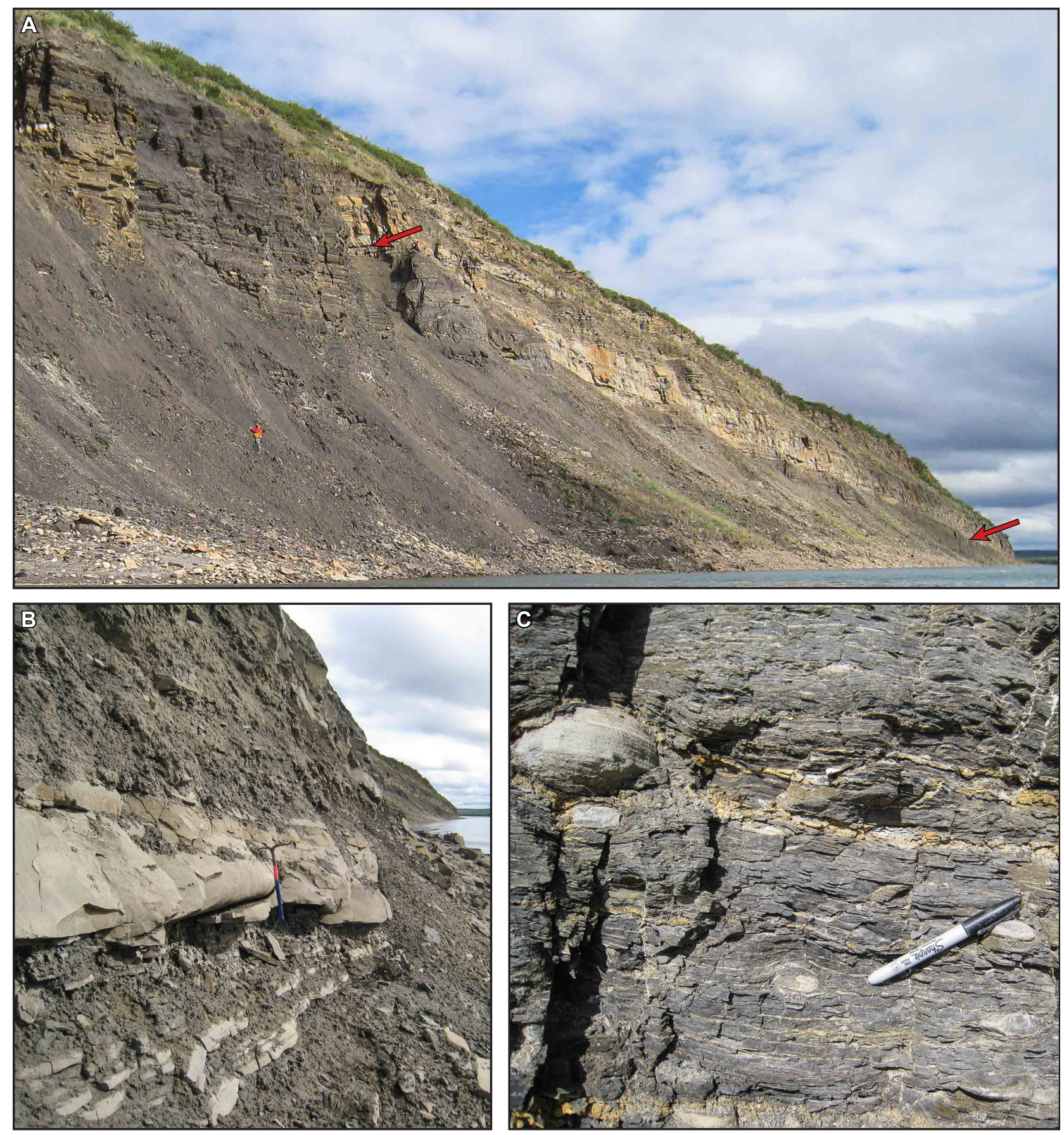

Figure 18. Field photographs of Seabee Formation at Umiat Mountain. A. View east-southeastward of mostly dark-gray-weathering Seabee exposed in the southwest-facing aspect of Umiat Mountain. The Seabee-Tuluvak contact is marked by red arrows. See figure 17A for a different perspective of this bluff. Geologist standing at lower left of photograph, for sense of scale. B. Thick sandstone beds are locally observed in the Seabee, which is dominantly bentonitic mudstone and shale that are mainly poorly exposed. Distant outcrop along point at river level is the same as in A. Mattock is $\sim 65 \mathrm{~cm}$ long. C. Detailed view of very thinly bedded, fissile character of commonly bentonitic strata in the Seabee. Marker is $14 \mathrm{~cm}$ long. Photographs by M.A. Wartes.

ering, medium-gray, thin- to very thickbedded, locally well indurated, commonly normally graded, low-angle cross-stratified (for example, hummocky, swaley, and irregularly) very fine-grained sandstone. Discrete, very thin-bedded bentonite hori- 
zons are common, and mudrock-dominated zones in the Seabee are typically covered in bentonitic slope wash that exhibits a characteristic "popcorn"-weathering style. Inoceramus shells, shell fragments, and prismatic calcite detritus are locally observed.

NANUSHUK FORMATION (regionally Albian-Cenomanian: Ahlbrandt and others, 1979; Huffman and others, 1985, 1988; LePain and others, 2009; Shimer and others, 2016; see review by Mull and others, 2003) (defined and/ or locally mapped by Schrader, 1902; Gryc and others, 1951; Detterman, 1956b; Detterman and others, 1963; Brosgé and Whittington, 1966; revised by Mull and others, 2003, 2004)_-The Nanushuk Formation (fig. 19) regionally records nonmarine and shallow-marine topset depositional systems that interfingered with slope foreset environments of the time-equivalent Torok Formation (Molenaar, 1985, 1988; Bird, 2001b; LePain and Kirkham, 2001; Houseknecht and Schenk, 2005; Decker, 2007; LePain and others, 2009) (fig. 4). Although the Torok does not crop out in the map area, it plays an important role in the study area's style of deformation and petroleum geology (see above). Houseknecht and Schenk (2005) mapped in the subsurface the ultimate (most basinward) Nanushuk-Torok shelf margin approximately $60 \mathrm{~km}$ east of Umiat ( $-20 \mathrm{~km}$ east of map area), where this important paleobathymetric element is north-trending and east-facing. Deposition of the uppermost Nanushuk (Ninuluk Formation of former usage; see revision by Mull and others, 2003) coincided with a basin-wide transgression (Detterman and others, 1963; Huffman and others, 1985, 1988), rendering retrogradational stacking of smaller-scale progradational packages of the youngest Nanushuk strata (LePain and others, 2009) as depositional systems backstepped to the west (Houseknecht and Schenk, 2005; Shimer and others, 2014). The larger-scale transgression ultimately terminated the NanushukTorok depositional cycle and yielded the basal transgressive Seabee Formation as described above.
Detailed sedimentologic work at Umiat Mountain (Houseknecht and Schenk, 2005) and the Colville incision locality (LePain and others, 2009) indicates that the upper Nanushuk of the study area records estuarine and shoreface sedimentation as well as fluvial processes. These reports are consistent with recent examination of Umiat oil field cores by Shimer and others (2014), who interpreted the Ninuluk as mainly reflecting retrogradational stacking of deltaic and shoreface deposits.

The Nanushuk in the Umiat and Gubik fields is reported to be 300-330 m thick (Collins, 1958; Robinson, 1958; Molenaar, 1982), although the unit thickens markedly to the south and west (Bird, 1988c). The Nanushuk thins to zero depositional thickness to the east at the aforementioned terminal Nanushuk-Torok shelf margin. Nanushuk outcrops in the mapped area mostly correspond to the Ninuluk Formation of former usage (see Mull and others, 2003). Good exposures of these rocks occur along the western extent of the south face of Umiat Mountain, where some sandstone beds are oil saturated (Houseknecht and Schenk, 2005) and probably associated with seeps near the bank of the Colville River. The Colville incision also permits examination of the uppermost Nanushuk Formation (see LePain and others, 2009; fig. 19). Older (Albian) Nanushuk sandstones host the main hydrocarbon accumulation at the Umiat field (Molenaar, 1982; Shimer and others, 2014; Hanks and others, 2014; this study), which is the only proven oil field in the Brooks Range foothills (see above).

Kn NANUSHUK FORMATION (locally Cenomanian: see Houseknecht and Schenk, 2005; LePain and others, 2009; see also Shimer and others, 2016; Albian to Cenomanian in the subsurface: see Molenaar, 1982)_-Tan- to graybrown- to rusty-brown-weathering, medium-gray to light-brown to gray-brown, thick- to very thick-bedded, dominantly well indurated, commonly normally graded, locally structureless but commonly trough, hummocky, swaley, or tabular (planar and tangential) cross-stratified, chiefly fine- to 

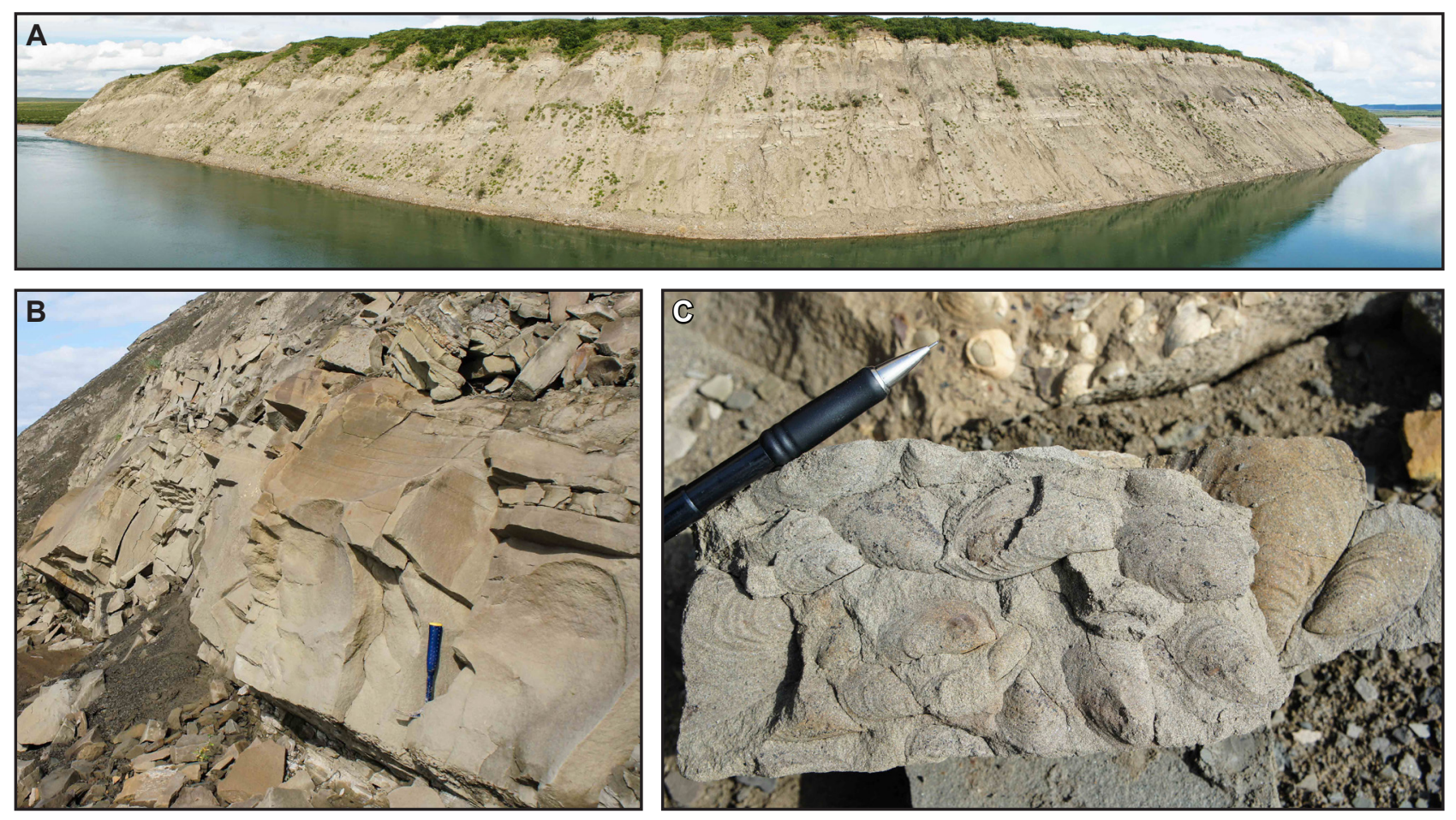

Figure 19. Field photographs of Nanushuk Formation at the Colville incision locality. A. Oblique aerial view northward of the uppermost nearly $100 \mathrm{~m}$ of the Nanushuk Formation (see LePain and others, 2009). Seabee Formation is mapped at and beyond the top of the bluff. Outcrop extends for $\sim 1 \mathrm{~km}$ along river and topographic relief of bluff near center of photograph is $\sim 45 \mathrm{~m}$, for sense of scale. Prominent barrel distortion of image is a perspective effect of stitching numerous photographs together to compose the panorama. B. Typical outcrop character of thick-bedded, structureless to cross-stratified sandstone of the Nanushuk Formation. Hammer is $31 \mathrm{~cm}$ long. C. Highly fossilifereous horizons are commonly associated with pebbly lag deposits in marine (probably shoreface) sandstones at this locality (see LePain and others, 2009). Pencil at rubberized grip is $1.2 \mathrm{~cm}$ diameter. Photographs by T.M. Herriott.

medium-grained sandstone. The fine- to medium-grained sandstone lithofacies is commonly overlain by subordinate darkgray- to gray-brown- to light-rusty-brownweathering, medium-gray to tan-gray to tan, very thin- to thin-bedded, moderately well indurated, ripple to low-angle cross-laminated to plane-parallel laminated very fine-grained sandstone and mudstone. Centimeter-scale, coalified wood fragments and very thin pebbly lags are locally observed.

\section{ACKNOWLEDGMENTS}

The State of Alaska funded this study, with additional support from the U.S. Geological Survey's National Cooperative Geologic Mapping Program (STATEMAP award number G12AC20187). Work by, and discussions with, Gil Mull, Dave LePain, and Dave Houseknecht were invaluable to this study. Ken Helmold, Dolores van der Kolk, Grant Shimer, Pete Flaig, Julie Houle, Meg Kramer, and Don Krouskop also shared their knowledge of the Umiat-Gubik area. Richard Kemnitz provided many insights regarding field logistics. Our field camps at Umiat were operated by Horst Expediting and 70 North. Helicopter pilot Tom "Rat" Ratledge safely transported the crew during field campaigns. Trish Ekberg, Nina Harun, and Mike Hendricks served additional geographic information system (GIS) support. Simone Montayne managed metadata for this report. Kristen Janssen provided manuscript formatting and layout. We thank Dave LePain and Tom Homza for thorough reviews that improved the clarity and content of this paper. 


\section{REFERENCES}

Ahlbrandt, T.S., 1979, Introduction to geologic studies of the Nanushuk Group, North Slope, Alaska, in Ahlbrandt, T.S., ed., Preliminary geologic, petrologic, and paleontologic results of the study of Nanushuk Group rocks, North Slope, Alaska: U.S. Geological Survey Circular 794, p. 1-4.

Ahlbrandt, T.S., Huffman, A.C., Jr., Fox, J.E., and Pasternack, Ira, 1979, Depositional framework and reservoir-quality studies of selected Nanushuk Group outcrops, North Slope, Alaska, in Ahlbrandt, T.S., ed., Preliminary geologic, petrologic, and paleontologic results of the study of Nanushuk Group rocks, North Slope, Alaska: U.S. Geological Survey Circular 794, p. 14-31.

Allmendinger, R.W., Cardozo, Nestor, and Fisher, D.M., 2013, Structural Geology Algorithms: Vectors and Tensors: Cambridge University Press, Cambridge, England, 289 p.

Bailey, Alan, 2016, The headache of low oil flow through TAPS: Petroleum News, v. 21, no. 6, p. 7.

Biddle, K.T., and Christie-Blick, Nicholas, 1985, Glossary-Strike-slip deformation, basin formation, and sedimentation, in Biddle, K.T., and Christie-Blick, Nicholas, eds., Strike-slip deformation, basin formation, and sedimentation: Society of Economic Paleontologists and Mineralogists Special Publication No. 37, p. 375-386. https://doi.org/10.2110/pec.85.37.0361

Bird, K.J., 1981, Petroleum exploration of the North Slope in Alaska, U.S.A.: U.S. Geological Survey Open-File Report 81-227, 43 p.

1988a, The geologic basis for appraising undiscovered hydrocarbon resources in the National Petroleum Reserve in Alaska by the play-appraisal method, in Gryc, George, ed., Geology and exploration of the National Petroleum Reserve in Alaska, 1974 to 1982: U.S. Geological Survey Professional Paper 1399, p. 81-116.

-1988b, Alaskan North Slope stratigraphic nomenclature and data summary for government-drilled wells, in Gryc, George, ed., Geology and exploration of the National Petroleum Reserve in Alaska, 1974 to 1982: U.S. Geological Survey Professional Paper 1399, p. 317-355. 1988c, Structure-contour and isopach maps of the National Petroleum Reserve in Alaska, in Gryc, George, ed., Geology and exploration of the National Petroleum Reserve in Alaska, 1974 to 1982: U.S. Geological Survey Professional Paper 1399, p. 355-377.

2001a, Alaska: A twenty-first-century petroleum province, in Downey, M.W., Threet, J.C., and Morgan, W.A., eds., Petroleum provinces of the twenty-first century: American Association of Petroleum Geologists Memoir 74, p. 137-165.

2001b, Framework geology, petroleum systems, and play concepts of the National Petroleum Reserve-Alaska, in Houseknecht, D.W., ed., Petroleum plays and systems in the National Petroleum Reserve-Alaska: SEPM (Society for Sedimentary Geology) Core Workshop 21, p. 5-17. https://doi.org/10.2110/cor.01.01.0005

Bird, K.J., and Bader, J.W., 1987, Regional geologic setting and history of petroleum exploration, in Bird, K.J., and Magoon, L.B., eds., Petroleum geology of the northern part of the Arctic National Wildlife Refuge, northeastern Alaska: U.S. Geological Survey Bulletin 1778, p. 17-25.

Bird, K.J., and Houseknecht, D.W., 2011, Geology and petroleum potential of the Arctic Alaska petroleum province, in Spencer, A.M., Embry, A.F., Gautier, D.L., Stoupakova, A.V., and Sørensen, Kai, eds., Arctic petroleum geology: Memoirs of the Geological Society of London, v. 35, ch. 32, p. 485-499. https://doi.org/10.1144/M35.32

Bird, K.J., and Molenaar C.M., 1992, The North Slope foreland basin, in Macqueen, R.W., and Leckie, D.A., eds., Foreland basins and foldbelts: American Association of Petroleum Geologists Memoir 55, p. 363-393.

Blythe, A.E., Bird, J.M., and Omar, G.I., 1996, Deformational history of the central Brooks Range, Alaska-Results from fission-track and ${ }^{40} \mathrm{Ar} /{ }^{39} \mathrm{Ar}$ analyses: Tectonics, v. 15 , p. $440-455$. http://dx. doi.org/10.1029/95TC03053

Brooks, A.H., 1916, The Alaskan mining industry in 1915, in U.S. Geological Survey, Mineral resources of Alaska, report on progress of investigations in 1915: U.S. Geological Survey Bulletin 642, p. 16-72. 
Brosgé, W.P., and Whittington, C.L., 1966, Geology of the Umiat-Maybe Creek region, Alaska: U.S. Geological Survey Professional Paper 303-H, p. 501-638.

Cardozo, Nestor, and Allmendinger, R.W., 2013, Spherical projections with OSXStereonet: Computers \& Geosciences, v. 51, p. 193-205. https://doi.org/10.1016/j.cageo.2012.07.021

Carter, L.D., and Galloway, J.P., 1986, Engineering-geologic maps of northern Alaska, Umiat Quadrangle: U.S. Geological Survey Open-File Report 86-335, 2 sheets, scale 1:250,000, 16 p. Christie-Blick, Nicholas, and Biddle, K.T., 1985, Deformation and basin formation along strikeslip faults, in Biddle, K.T., and Christie-Blick, Nicholas, eds., Strike-slip deformation, basin formation, and sedimentation: Society of Economic Paleontologists and Mineralogists Special Publication 37, p. 1-34. https://doi. org/10.2110/pec.85.37.0001

Cole, Frances, Bird, K.J., Toro, Jaime, Roure, François, O'Sullivan, P.B., Pawlewicz, Mark, and Howell, D.G., 1997, An integrated model for the tectonic development of the frontal Brooks Range and Colville basin $250 \mathrm{~km}$ west of the Trans-Alaska Crustal Transect: Journal of Geophysical Research, v. 102, p. 20,68520,708. http://dx.doi.org/10.1029/96JB03670 Collins, F.R., 1958, Test wells, Umiat area, Alaska: U.S. Geological Survey Professional Paper 305B, 3 sheets, p. 71-206.

Decker, P.L., 2007, Brookian sequence stratigraphic correlations, Umiat Field to Milne Point Field, west-central North Slope, Alaska: Alaska Division of Geological \& Geophysical Surveys Preliminary Interpretive Report 20072, 1 sheet, $19 \mathrm{p}$.

2010, Brookian sequence stratigraphic framework of the northern Colville foreland basin, central North Slope, Alaska (poster and presentation): DNR Spring Technical Review Meeting, Anchorage, April 21-22, 2010: Alaska Division of Geological \& Geophysical Surveys, 1 sheet, $30 \mathrm{p}$.
Decker, P.L., and Wartes, M.A., 2008, Geochemistry of the Aupuk gas seep along the Colville River-Evidence for a thermogenic origin, in Wartes, M.A., and Decker, P.L., eds., Preliminary results of recent geologic field investigations in the Brooks Range Foothills and North Slope, Alaska: Alaska Division of Geological \& Geophysical Surveys Preliminary Interpretive Report 2008-1E, p. 47-54.

Detterman, R.L., 1956a, New member of Seabee formation, Colville Group, in Gryc, George, Bergquist, H.R., Detterman, R.L., Patton, W.W., Jr., Robinson, F.M., Rucker, F.P., and Whittington, C.L., Mesozoic sequence in Colville River region, northern Alaska: American Association of Petroleum Geologists Bulletin, v. 40 , no. 2, p. 253-254.

1956b, New and redefined nomenclature of Nanushuk group, in Gryc, George, Bergquist, H.R., Detterman, R.L., Patton, W.W., Jr., Robinson, F.M., Rucker, F.P., and Whittington, C.L., Mesozoic sequence in Colville River region, northern Alaska: American Association of Petroleum Geologists Bulletin, v. 40, no. 2, p. 233-244.

Detterman, R.L., Bickel, R.S., and Gryc, George, 1963, Geology of the Chandler River region, Alaska: U.S. Geological Survey Professional Paper 303-E, p. 223-324.

Division of Oil and Gas, 2008, Regional geology of the North Slope (plate 2 of 4): Alaska Department of Natural Resources, North Slope Resource Series, scale 1:1,000,000.

Flaig, P.P., 2010, Depositional environments of the Late Cretaceous (Maastrichtian) dinosaur-bearing Prince Creek Formation: Colville River region, North Slope, Alaska: University of Alaska Fairbanks, Ph.D. dissertation, 311 p.

Flaig, P.P., Fiorillo, A.R., and McCarthy, P.J., 2014, Dinosaur-bearing hyperconcentrated flows of Cretaceous Arctic Alaska: Recurring catastrophic event beds on a distal paleopolar coastal plain: PALAIOS, v. 29, p. 594-611. https://doi.org/10.2110/palo.2013.133 
Flaig, P.P., McCarthy, P.J., and Fiorillo, A.R. 2011, A tidally influenced, high-latitude coastal-plain: The Upper Cretaceous (Maastrichtian) Prince Creek Formation, North Slope, Alaska, in Davidson, S.K., Leleu, Sophie, and North, C.P., eds., From river to rock record: The preservation of fluvial sediments and their subsequent interpretation: SEPM (Society for Sedimentary Geology) Special Publication 97, p. 233-264. https:// doi.org/10.2110/sepmsp.097.233

2013, Anatomy, evolution, and paleoenvironmental interpretation of an ancient Arctic coastal plain: Integrated paleopedology and palynology from the Upper Cretaceous (Maastrichtian) Prince Creek Formation, North Slope, Alaska, USA, in Driese, S.G., Nordt, L.C., and McCarthy, P.J., eds., New frontiers in paleopedology and terrestrial paleoclimatology: Paleosols and soil surface analog systems: SEPM (Society for Sedimentary Geology) Special Publication 104, p. 179-230. https://doi.org/10.2110/ sepmsp. 104

Flores, R.M., Myers, M.D., Houseknecht, D.W., Stricker, G.D., Brizzolara, D.W., Ryherd, T.J., and Takahashi, K.I., 2007a, Stratigraphy and facies of Cretaceous Schrader Bluff and Prince Creek Formations in Colville River Bluffs, North Slope, Alaska: U.S. Geological Survey Professional Paper 1748, 45 p.

Flores, R.M., Stricker, G.D., Decker, P.L., and Myers, M.D., 2007b, Sentinel Hill core test $1-\mathrm{Fa}-$ cies descriptions and stratigraphic reinterpretations of the Prince Creek and Schrader Bluff Formations, North Slope, Alaska: U.S. Geological Survey Professional Paper 1747, $34 \mathrm{p}$.

Garrity, C.P., Houseknecht, D.W., Bird, K.J., Potter, C.J., Moore, T.E., Nelson, P.H., and Schenk, C.J., 2005, U.S. Geological Survey 2005 oil and gas resource assessment of the central North Slope, Alaska—Play maps and results: U.S. Geological Survey Open-File Report 2005-1182, 1 p. Gillis, R.J., Decker, P.L., Wartes, M.A., Loveland, A.M., and Hubbard, T.D., 2014, Geologic map of the south-central Sagavanirktok Quadrangle, North Slope, Alaska: Alaska Division of Geolog- ical \& Geophysical Surveys Report of Investigation 2014-4, 2 sheets, scale 1:63,360, 24 p.

Grantz, Arthur, Dinter, D.A., and Biswas, N.N., 1983, Map, cross sections, and chart showing late Quaternary faults, folds, and earthquake epicenters on the Alaskan Beaufort shelf: U.S. Geological Survey Miscellaneous Investigations Series Map I-1182-C, 3 sheets, scale 1:500,000, $7 \mathrm{p}$.

Grantz, Arthur, May, S.D., and Hart, P.E., 1990, Geology of the Arctic continental margin of Alaska, in Grantz, Arthur, Johnson, Leonard, and Sweeney, J.F., eds., The Arctic Ocean region: The Geology of North America, Geological Society of America, Boulder, Colorado, v. L, ch. 16, p. 257-288. https://doi.org/10.1130/DNAGGNA-L.257

Gryc, George, 1956, Introduction and summary, in Gryc, George, Bergquist, H.R., Detterman, R.L., Patton, W.W., Jr., Robinson, F.M., Rucker, F.P., and Whittington, C.L., Mesozoic sequence in Colville River region, northern Alaska: American Association of Petroleum Geologists Bulletin, v. 40, no. 2, p. 209-214.

Gryc, George, ed., 1988, Geology and exploration of the National Petroleum Reserve in Alaska, 1974 to 1982: U.S. Geological Survey Professional Paper 1399, $940 \mathrm{p}$.

Gryc, George, Bergquist, H.R., Detterman, R.L., Patton, W.W., Jr., Robinson, F.M., Rucker, F.P., and Whittington, C.L., 1956, Mesozoic sequence in Colville River region, northern Alaska: American Association of Petroleum Geologists Bulletin, v. 40, no. 2, p. 209-254.

Gryc, George, Patton, W.W., Jr., and Payne, T.G., 1951, Present Cretaceous stratigraphic nomenclature of northern Alaska: Washington Academy of Sciences Journal, v. 41, no. 5, p.159-167. Hanks, C.L., Shimer, Grant, Kohshour, Iman Oraki, Ahmadi, Mohabbat, McCarthy, P.J., Dandekar, Abhijit, Mongrain, Joanna, Wentz, Raelene, 2014, Integrated reservoir characterization and simulation of a shallow, light-oil, low-temperature reservoir: Umiat field, National Petroleum Reserve, Alaska: American Association of Petroleum Geologists Bulletin, v. 98, p. 563-585. https:// doi.org/10.1306/08201313011 
Harding, T.P., and Lowell, J.D., 1979, Structural styles, their plate-tectonic habitats, and hydrocarbon traps in petroleum provinces: American Association of Petroleum Geologists Bulletin, v. 63 , p. $1,016-1,058$.

Herriott, T.M., and others, in preparation, Geologic map of the Gilead Creek area, northeastern Brooks Range, Alaska: Alaska Division of Geological \& Geophysical Surveys Report of Investigation.

Houseknecht, D.W., and Bird, K.J., 2006, Oil and gas resources of the Arctic Alaska petroleum province, in Haeussler, P.J., and Galloway, J.P., eds., Studies by the U.S. Geological Survey in Alaska, 2005: U.S. Geological Survey Professional Paper 1732-A, $11 \mathrm{p}$.

Houseknecht, D.W., Bird, K.J., and Schenk, C.J., 2009, Seismic analysis of clinoform depositional sequences and shelf-margin trajectories in Lower Cretaceous (Albian) strata, Alaska North Slope: Basin Research, v. 21, p. 644-654. http://dx.doi. org/10.1111/j.1365-2117.2008.00392.x

Houseknecht, D.W, and Schenk, C.J., 2001, Depositional sequences and facies in the Torok Formation, National Petroleum Reserve-Alaska (NPRA), in Houseknecht, D.W., ed., Petroleum plays and systems in the National Petroleum Reserve-Alaska: SEPM (Society for Sedimentary Geology) Core Workshop 21 p. 179-199. https:// doi.org/10.2110/cor.01.01.0179

2005, Sedimentology and sequence stratigraphy of the Cretaceous Nanushuk, Seabee, and Tuluvak Formations exposed on Umiat Mountain, north-central Alaska: U.S. Geological Survey Professional Paper 1709-B, 18 p.

Hubbard, R.J., Edrich, S.P., and Rattey, R.P., 1987, Geologic evolution and hydrocarbon habitat of the Arctic Alaska microplate, in Tailleur, I.L., and Weimer, Paul, eds., Alaskan North Slope geology: Society of Economic Paleontologists and Mineralogists, Pacific Section, and Alaska Geological Society, Book 50, v. 2, p. 797-830.

Huffman, A.C., ed., 1985, Geology of the Nanushuk Group and related rocks, North Slope, Alaska: U.S. Geological Survey Bulletin 1614, 129 p.

Huffman, A.C., Jr., Ahlbrandt, T.S., and Bartsch-Winkler, Susan, 1988, Sedimentology of the Nanushuk Group, North Slope, in Gryc, George, ed., Geology and exploration of the National Petroleum Reserve in Alaska, 1974 to 1982: U.S. Geological Survey Professional Paper 1399, p. 281-298.

Huffman, A.C., Ahlbrandt, T.S., Pasternack, Ira, Stricker, G.D., and Fox, J.E., 1985, Depositional and sedimentologic factors affecting the reservoir potential of the Cretaceous Nanushuk Group, central North Slope, in Huffman, A.C., ed., Geology of the Nanushuk Group and related rocks, North Slope, Alaska: U.S. Geological Survey Bulletin 1614, p. 61-74.

Jones, D.L., and Gryc, George, 1960, Upper Cretaceous pelecypods of the genus Inoceramus from northern Alaska: U.S. Geological Survey Professional Paper 334-E, p. 149-165.

Kelley, J.S., 1990, Generalized geologic map of the Chandler Lake Quadrangle, north-central Alaska: U.S. Geological Survey Miscellaneous Field Studies Map 2144-A, 1 sheet, scale 1:250,000, 19 p.

Kirschner, C.E., and Rycerski, B.A., 1988, Petroleum potential of representative stratigraphic and structural elements in the National Petroleum Reserve in Alaska, in Gryc, George, ed., Geology and exploration of the National Petroleum Reserve in Alaska, 1974 to 1982: U.S. Geological Survey Professional Paper 1399, p. 191-208.

Kopf, R.W., 1970, Geologic names in use north of the Brooks Range, Alaska, in Adkison, W.L., and Brosgé, M.M., eds., Proceedings of the geologic seminar on the North Slope of Alaska: American Association of Petroleum Geologists, Pacific Section, p. Q1-Q5.

Kornbrath, R.W., Myers, M.D., Krouskop, D.L., Meyer, J.F., Houle, J.A., Ryherd, T.J., and Richter, K.N., 1997, Petroleum potential of the eastern National Petroleum Reserve-Alaska: Alaska Department of Natural Resources, Division of Oil and Gas, 30 p.

Kumar, Naresh, Bird, K.J., Nelson, P.H., Grow, J.A., and Evans, K.R., 2002, A digital atlas of hydrocarbon accumulations within and adjacent to the National Petroleum Reserve-Alaska (NPRA): U.S. Geological Survey Open-File Report 2002-71, 80 p. 
Lanphere, M.A., and Tailleur, I.L., 1983, K-Ar ages of bentonites in the Seabee Formation, northern Alaska: A Late Cretaceous (Turonian) time-scale point: Cretaceous Research, v. 4, p. 361-370. https://doi.org/10.1016/S01956671(83)80004-4

Leffingwell, E. de K., 1919, The Canning River region, northern Alaska: U.S. Geological Survey Professional Paper 109, 6 sheets, various scales, $251 \mathrm{p}$.

LePain, D.L., and Kirkham, R.A., 2001, Potential reservoir facies in the Nanushuk Formation (Albian-Cenomanian), central North Slope, Alaska: Examples from outcrop and core, in Houseknecht, D.W., ed., Petroleum plays and systems in the National Petroleum ReserveAlaska: SEPM (Society for Sedimentary Geology) Core Workshop 21, p. 19-36. https://doi. org/10.2110/cor.01.01.0019

LePain, D.L., McCarthy, P.J., and Kirkham, Russell, 2009, Sedimentology and sequence stratigraphy of the middle Albian-Cenomanian Nanushuk Formation in outcrop, central North Slope, Alaska: Alaska Division of Geological \& Geophysical Surveys Report of Investigation 2009-1, 1 sheet. 78 p. Lerand, M., 1973, Beaufort Sea, in McCrossam, R.G., ed., The future petroleum provinces of Canada-Their geology and potential: Canadian Society of Petroleum Geology Memoir 1, p. 315-386.

Lidji, Eric, 2012, Umiat reserves saga: Petroleum News, v. 17 , no. 36, p. 1 and 15.

2015a, Linc outlines Umiat: Petroleum News, v. 20, no. 25, p. 1 and 19.

2015b, New Umiat report drops reserves, lowers recoverable based on price: Petroleum News, v. 20, no. 51, p.1 and 15.

2016, Market challenges two Linc Energy projects: The Explorers, Petroleum News, v. 21, no. 21, p. 53-54.

Magoon, L.B., III, 1994, Petroleum resources in Alaska, in Plafker, George, and Berg, H.C., eds., The Geology of Alaska: The Geology of North America, Geological Society of America, Boulder, Colorado, v. G-1, ch. 30, p. 905-936. https://doi.org/10.1130/DNAG-GNA-G1.905
Magoon, L.B., and Bird, K.J., 1985, Alaskan North Slope petroleum geochemistry for the Shublik Formation, Kingak Shale, pebble shale unit, and Torok Formation, in Magoon, L.B., and Claypool, G.E., eds., Alaska North Slope oil/rock correlation study: American Association of Petroleum Geologists Studies in Geology 20, p. 31-48.

Magoon, L.B., Lillis, P.G., Bird, K.J., Lampe, C., and Peters, K.E., 2003, Alaskan North Slope petroleum systems: U.S. Geological Survey OpenFile Report 2003-324, 3 sheets.

Marrett, R.A., and Allmendinger, R.W., 1990, Kinematic analysis of fault-slip data: Journal of Structural Geology, v. 12, p. 973-986. https:// doi.org/10.1016/0191-8141(90)90093-E

Mayfield, C.F., Tailleur, I.L., and Ellersieck, Inyo, 1988, Stratigraphy, structure, and palinspastic synthesis of the western Brooks Range, northwestern Alaska, in Gryc, George, ed., Geology and exploration of the National Petroleum Reserve in Alaska, 1974 to 1982: U.S. Geological Survey Professional Paper 1399, 4 sheets, p. $143-186$.

McClay, K.R., 1987, The Mapping of Geological Structures: John Wiley \& Sons, Chichester, 161 p. Miller, E.L., and Hudson, T.L., 1991, Mid-Cretaceous extensional fragmentation of a JurassicEarly Cretaceous compressional orogen, Alaska: Tectonics, v. 10, p. 781-796. http://dx.doi. org/10.1029/91TC00044

Molenaar, C.M., 1982, Umiat field, an oil accumulation in a thrust-faulted anticline, North Slope of Alaska, in Powers, R.B., ed., Geologic studies of the Cordilleran thrust belt: Rocky Mountain Association of Geologists, p. 537-548.

Molenaar, C.M., 1983, Depositional relations of Cretaceous and lower Tertiary rocks, northeastern Alaska: American Association of Petroleum Geologists Bulletin, v. 67, p. 1,066-1,080.

Molenaar, C.M., 1985, Subsurface correlations and depositional history of the Nanushuk Group and related strata, North Slope, Alaska, in Huffman, A.C., ed., Geology of the Nanushuk Group and related rocks, North Slope, Alaska: U.S. Geological Survey Bulletin 1614, p. 37-59. 
1988, Depositional history and seismic stratigraphy of Lower Cretaceous rocks in the National Petroleum Reserve in Alaska and adjacent areas, in Gryc, George, ed., Geology and exploration of the National Petroleum Reserve in Alaska, 1974 to 1982: U.S. Geological Survey Professional Paper 1399, p. 593-621.

Molenaar, C.M., Bird, K.J., and Kirk, A.R., 1987, Cretaceous and Tertiary stratigraphy of northeastern Alaska, in Tailleur, I.L., and Weimer, Paul, eds., Alaskan North Slope geology: Society of Economic Paleontologists and Mineralogists, Pacific Section, and Alaska Geological Society, Book 50, v. 2, p. 513-528.

Moore, T.E., and Box, S.E., 2016, Age, distribution and style of deformation in Alaska north of $60^{\circ} \mathrm{N}$ : Implications for assembly of Alaska: Tectonophysics, v. 691, p. 133-170. https://doi. org/10.1016/j.tecto.2016.06.025

Moore, T.E., Potter, C.J., O’Sullivan, P.B., Shelton, K.L., and Underwood, M.B., 2004, Two stages of deformation and fluid migration in the west-central Brooks Range fold and thrust belt, northern Alaska, in Swennen, Rudy, Roure, François and Granath, J.W., eds., Deformation, fluid flow, and reservoir appraisal in foreland fold and thrust belts: American Association of Petroleum Geologists Hedberg Series, no.1, p. 157-186.

Moore, T.E., Wallace, W.K., Bird, K.J., Karl, S.M., Mull, C.G., and Dillon, J.T., 1994, Geology of northern Alaska, in Plafker, George, and Berg, H.C., eds., The Geology of Alaska: The Geology of North America, Geological Society of America, Boulder, Colorado, v. G-1, p. 49-140. https://doi.org/10.1130/DNAG-GNA-G1.49

Mull, C.G., 1979, Nanushuk Group deposition and the late Mesozoic structural evolution of the central and western Brooks Range and Arctic Slope, in Ahlbrandt, T.S., ed., Preliminary geologic, petrologic, and paleontologic results of the study of Nanushuk Group rocks, North Slope, Alaska: U.S. Geological Survey Circular 794, p. 5-13.

1982, The tectonic evolution and structural style of the Brooks Range, Alaska: An illustrated summary, in Powers, R.B., ed., Geological studies of the Cordilleran thrust Belt, Volume 1: Rocky
Mountain Association of Geologists, p. 1-45. 1985, Cretaceous tectonics, depositional cycles, and the Nanushuk Group, Brooks Range and Arctic Slope, Alaska, in Huffman, A.C., ed., Geology of the Nanushuk Group and related rocks, North Slope, Alaska: U.S. Geological Survey Bulletin 1614, p. 7-36.

Mull, C.G., Glenn, R.K., and Adams, K.E., 1997, Tectonic evolution of the central Brooks Range mountain front: Evidence from the Atigun Gorge region: Journal of Geophysical Research, v. 102, p. 20,749-20,773. http://dx.doi.org/10.1029/ 96JB03732

Mull, C.G., Harris, E.E., Delaney, P.R., and Swenson, R.F., 2009, Geology of the Cobblestone Creek-May Creek area, east-central Brooks Range Foothills, Alaska: Alaska Division of Geological \& Geophysical Surveys Preliminary Interpretive Report 2009-5, 1 sheet, scale 1:63,360, 40 p.

Mull, C.G., Houseknecht, D.W., and Bird, K.J., 2003, Revised Cretaceous and Tertiary stratigraphic nomenclature in the Colville basin, northern Alaska: U.S. Geological Survey Professional Paper 1673, 51 p.

Mull, C.G., Houseknecht, D.W., Pessel, G.H., and Garrity, C.P., 2004, Geologic map of the Umiat Quadrangle, Alaska: U.S. Geological Survey Scientific Investigations Map 2817-A, 1 sheet, scale 1:250,000.

2005, Geologic map of the Ikpikpuk River Quadrangle, Alaska: U.S. Geological Survey Scientific Investigations Map 2817-B, 1 sheet, scale $1: 250,000$.

Oldow, J.S., Seidensticker, C.M., Phelps, J.C., Julian, F.E., Gottschalk, R.R., Boler, K.W., Handschy, J.W., and Ave Lallemant, H.G., 1987, Balanced cross sections through the central Brooks Range and North Slope, Arctic Alaska: American Association of Petroleum Geologists, 8 plates, 19 p.

O'Sullivan, P.B., 1996, Late Mesozoic and Cenozoic thermotectonic evolution of the Colville basin, North Slope, Alaska, in Johnsson, M.J., and Howell, D.G., eds., Thermal evolution of sedimentary basins in Alaska: U.S. Geological Survey Bulletin 2142, p. 45-79. 
O’Sullivan, P.B., Green, P.F., Bergman, S.C., Decker, John, Duddy, I.R., Gleadow, A.J.W., and Turner, D.L., 1993, Multiple phases of Tertiary uplift and erosion in the Arctic National Wildlife Refuge, Alaska, revealed by apatite fission track analysis: American Association of Petroleum Geologists Bulletin, v. 77, p. 359-385.

O'Sullivan, P.B., Murphy, J.M., and Blythe, A.E., 1997, Late Mesozoic and Cenozoic thermotectonic evolution of the central Brooks Range and adjacent North Slope foreland basin, Alaska: Including fission track results from the Trans-Alaska Crustal Transect (TACT): Journal of Geophysical Research, v. 102, p. 20,821-20,845. http://dx.doi.org/10.1029/96JB03411

O'Sullivan, P.B., and Wallace, W.K., 2002, Outof-sequence, basement-involved structures in the Sadlerochit Mountains region of the Arctic National Wildlife Refuge, Alaska-Evidence and implications from fission-track thermochronology: Geological Society of America Bulletin, v. 114 , p. 1,356-1,378. https://doi.org/10 .1130/0016-7606(2002)114\%3C1356:OOSBIS\%3E2.0.CO;2

O'Sullivan, P.B., Wallace, W.K. and Murphy, J.M., 1998, Fission track evidence for apparent out-of-sequence Cenozoic deformation along the Philip Smith Mountain front, northeastern Brooks Range, Alaska: Earth and Planetary Science Letters, v. 164, p. 435-449. https://doi. org/10.1016/S0012-821X(98)00237-4

Peters, K.E., Magoon, L.B., Bird, K.J., Valin, Z.C., and Keller, M.A., 2006, North Slope Alaska: Source-rock distribution, richness, thermal maturity and petroleum charge: American Association of Petroleum Geologists Bulletin, v. 90, p. 261292. https://doi.org/10.1306/09210505095

Reed, J.C., 1958, Exploration of Naval Petroleum Reserve No. 4 and adjacent areas, northern Alaska, 1944-53; Part 1, History of the exploration: U.S. Geological Survey Professional Paper 301, 2 sheets, scale 1:1,000,000, $192 \mathrm{p}$.

Reger, R.D., Stevens, D.S.P., Cruse, G.R., and Livingston, H.R., 2003, Survey of geology, geologic materials, and geologic hazards in proposed access corridors in selected quadrangles, Alaska:
Alaska Division of Geological \& Geophysical Surveys Miscellaneous Publication, 72 p.

Robinson, F.M., 1958, Test wells, Gubik area, Alaska: U.S. Geological Survey Professional Paper 305-C, 2 sheets, p. 207-264.

Sanders, C.M., 2014, Structural geology of the Big Bend anticline, Brooks Range foothills, Alaska: University of Alaska Fairbanks, master's thesis, $153 \mathrm{p}$.

Schindler, J.F., 1988, History of exploration in the National Petroleum Reserve in Alaska, with emphasis on the period from 1975 to 1982, in Gryc, George, ed., Geology and exploration of the National Petroleum Reserve in Alaska, 1974 to 1982: U.S. Geological Survey Professional Paper 1399, p. 13-72.

Schrader, F.C., 1902, Geological section of the Rocky Mountains in northern Alaska: Geological Society of America Bulletin, v. 13, p. 233-252. https://doi.org/10.1130/GSAB-13-233

Schrader, F.C., 1904, A reconnaissance in northern Alaska across the Rocky Mountains, along Koyukuk, John, Anaktuvuk, and Colville rivers and the Arctic Coast to Cape Lisburne, in 1901: U.S. Geological Survey Professional Paper 20, 2 sheets, scale 1:1,250,000, 139 p.

Shimer, Grant, 2013, Sedimentology and stratigraphy of the Nanushuk Formation and related foreland basin deposits, central Brooks Range foothills, Alaska: University of Alaska Fairbanks, Ph.D. dissertation, $165 \mathrm{p}$.

Shimer, G.T., Benowitz, J.A., Layer, P.W., McCarthy, P.J., Hanks, C.L., and Wartes, M.A., 2016, ${ }^{40} \mathrm{Ar} /{ }^{39} \mathrm{Ar}$ ages and geochemical characterization of Cretaceous bentonites in the Nanushuk, Seabee, Tuluvak, and Schrader Bluff formations, North Slope, Alaska: Cretaceous Research, v. 57, p. 325-341. https://doi.org/10.1016/j.cretres.2015.04.008

Shimer, G.T., McCarthy, P.J., and Hanks, C.L., 2014, Sedimentology, stratigraphy, and reservoir properties of an unconventional, shallow, frozen petroleum reservoir in the Cretaceous Nanushuk Formation at Umiat Field, North Slope, Alaska: American Association of Petroleum Geologists Bulletin, v. 98, p. 631-661. https://doi. org/10.1306/09031312239 
Smith, P.S. and Mertie, J.B., Jr., 1930, Geology and mineral resources of northwestern Alaska: U.S. Geological Survey Bulletin 815, 4 sheets, scale 1:500,000, $351 \mathrm{p}$.

Stevens, D.S.P., Reger, R.D., and Smith, R.L., 2003, Survey of geology, geologic materials, and geologic hazards in proposed access corridors in the Umiat Quadrangle, Alaska: Alaska Division of Geological \& Geophysical Surveys Miscellaneous Publication, 5 sheets, scale 1:250,000.

Sylvester, A.G., 1988, Strike-slip faults: Geological Society of America Bulletin, v. 100, p. 1,6661,703. https://doi.org/10.1130/0016-7606(19 88) $100 \% 3 \mathrm{C} 1666:$ SSF\%3E2.3.CO;2

Till, A.B., 1992, Detrital blueschist-facies metamorphic mineral assemblages in Early Cretaceous sediments of the foreland basin of the Brooks Range, Alaska, and implications for orogenic evolution: Tectonics, v. 11, p. 1,207-1,223. http://dx.doi. org/10.1029/92TC01104

Till, A.B., and Snee, L.W., 1995, 40Ar/39Ar evidence that formation of blueschists in continental crust was synchronous with foreland fold and thrust belt deformation, western Brooks Range, Alaska: Journal of Metamorphic Geology, v. 13, p. 41-60. http://dx.doi.org/10.1111/j.1525-1314.1995. tb00204.x

Triezenberg, P.J., Hart, P.E., and Childs, J.R., 2016, National Archive of Marine Seismic Surveys (NAMSS): A USGS data website of marine seismic reflection data within the U.S. Exclusive Economic Zone (EEZ): U.S. Geological Survey Data Release.

Turner, D.L., Forbes, R.B., and Dillon, J.T., 1979 K-Ar geochronology of the southwestern Brooks Range, Alaska: Canadian Journal of Earth Sciences, v. 16, p. 1,789-1,804. https://doi.org/10.1139/e79-164

Twiss, R.J., and Moores, E.M., 1992, Structural Geology: W.H. Freeman and Company, New York, $532 \mathrm{p}$.

van der Kolk, D.A, 2016, Marine-continental transitions in a greenhouse world: Reconstructing Late
Cretaceous deltas of paleopolar Arctic Alaska and Utah: The University of Texas at Austin, Ph.D. dissertation, $297 \mathrm{p}$.

van der Kolk, D.A., Flaig, P.P., and Hasiotis, S.T., 2015, Paleoenvironmental reconstruction of a Late Cretaceous, muddy, river-dominated polar deltaic system: Schrader Bluff-Prince Creek Formation transition, Shivugak Bluffs, North Slope of Alaska, U.S.A.: Journal of Sedimentary Research, v. 8, p. 903-936. https://doi.org/10.2110/ jsr.2015.58

Vogl, J.J., Calvert, A.T., and Gans, P.B., 2002, Mechanisms and timing of exhumation of collision-related metamorphic rocks, southern Brooks Range, Alaska: Insights from 40Ar/39Ar thermochronology: Tectonics, v. 21, p. 2-1-2-17. http://dx.doi. org/10.1029/2000TC001270

Wallace, W.K., 2008, Mechanical stratigraphy and the structural geometry and evolution of the central and eastern foothills of the Brooks Range, northern Alaska, in Hanks, C.L., ed., Unraveling the Timing of Fluid Migration and Trap Formation in the Brooks Range Foothills: A Key to Discovering Hydrocarbons: Final Report, prepared for U.S. Department of Energy, National Energy Technology Laboratory (DOE Award Number DE-FC26-06NT41248), p. 2-1-2-34.

Watt, J.S., Huckabay, Allen, and Landt, M.R., 2010, Umiat: A North Slope giant primed for oil development: Oil and Gas Journal, v. 108, issue 1.

Wentz, Raelene, 2014, Fracture characteristics and distribution in Cretaceous rocks near the Umiat anticline, North Slope of Alaska: University of Alaska Fairbanks, master's thesis, 154 p.

Whittington, C.L., 1956, Revised stratigraphic nomenclature of Colville Group, in Gryc, George, Bergquist, H.R., Detterman, R.L., Patton, W.W., Jr., Robinson, F.M., Rucker, F.P., and Whittington, C.L., Mesozoic sequence in Colville River region, northern Alaska: American Association of Petroleum Geologists Bulletin, v. 40, no. 2, p. 244-253. 


\section{APPENDIX 1}

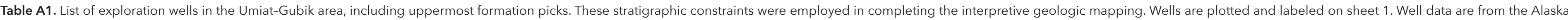

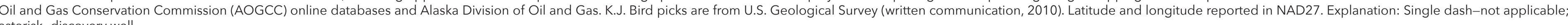
asterisk-discovery well.

\begin{tabular}{|c|c|c|c|c|c|c|c|c|c|c|}
\hline Field Name & Well Name & Well Operator & $\underset{\text { Date }}{\text { Completion }}$ & Latitude & Longitude & \begin{tabular}{|c} 
Uppermost \\
Formation \\
Pick
\end{tabular} & $\begin{array}{c}\text { Measured } \\
\text { Depth (feet) }\end{array}$ & Pick Source & Comment (this study) & Interpretation (this study) \\
\hline \multirow{14}{*}{ Umiat oil field } & Umiat Test No. 1 & U.S. Navy & 10/05/1946 & 69.396529 & -152.329178 & Seabee & $9-915$ & K.J. Bird & - & Seabee at surface \\
\hline & Umiat Test No. 2 & U.S. Navy & $12 / 12 / 1947$ & 69.384463 & -152.083611 & Nanushuk & $80-1060$ & K.J. Bird & Quaternary: 9-80' (Collins, 1958) & Nanushuk near surface \\
\hline & Umiat Test No. $3^{*}$ & U.S. Navy & $12 / 26 / 1946$ & 69.387807 & -152.087284 & Nanushuk & 60-total depth & K.J. Bird & \begin{tabular}{|c|} 
not sampled: 9-60' (Collins, 1958); total depth \\
at 572' in Kn (Collins, 1958)
\end{tabular} & Nanushuk near surface \\
\hline & Umiat Test No. 4 & U.S. Department of Interior & $07 / 29 / 1950$ & 69.388905 & -152.081419 & Nanushuk & 90-total depth & K.J. Bird & \begin{tabular}{|c|} 
not sampled: 1-90' (Collins; 1958); total depth \\
at $840^{\prime}$ 'in Kn (Collins, 1958) \\
\end{tabular} & Nanushuk near surface \\
\hline & Umiat Test No. 5 & U.S. Department of Interior & $10 / 4 / 1951$ & 69.384739 & -152.082264 & Nanushuk & $65-1060$ & Collins (1958) & \begin{tabular}{|c|} 
not sampled: 0-65' (Collins, 1958); probably \\
spudded in Kn (Collins, 1958)
\end{tabular} & Nanushuk near surface \\
\hline & Umiat Test No. 6 & U.S. Navy & $12 / 12 / 1950$ & 69.378915 & -152.094441 & Seabee & $30-220$ & K.J. Bird & $\begin{array}{c}\text { not sampled: 3-100' (Collins, 1958); top of Ks } \\
\text { at 31' (Collins, 1958) }\end{array}$ & Seabee near surface \\
\hline & Umiat Test No. 7 & U.S. Navy & $04 / 12 / 1951$ & 69.375850 & -152.104716 & Seabee & $50-380$ & K.J. Bird & Quaternary: 4-50' (Collins, 1958) & Seabee near surface \\
\hline & Umiat Test No. 8 & U.S. Department of Interior & $08 / 28 / 1951$ & 69.399748 & -152.115565 & Seabee & $20-60$ & K.J. Bird & Quaternary: 5-20' (Collins, 1958) & Seabee near surface \\
\hline & Umiat Test No. 9 & U.S. Navy & 01/15/1952 & 69.387244 & -152.169749 & Nanushuk & $6-1090$ & K.J. Bird; Collins (1958) & - & Nanushuk at surface \\
\hline & Umiat Test No. 10 & U.S. Navy & 01/10/1952 & 69.401132 & -152.132500 & Nanushuk & $5-250$ & K.J. Bird & Nanushuk thrusted over Seabee at 250' & Nanushuk near surface \\
\hline & Umiat Test No. 11 & U.S. Navy & $08 / 29 / 1952$ & 69.408078 & -152.099460 & Tuluvak & $22-775$ & K.J. Bird & - & Tuluvak near surface \\
\hline & Seabee Test No. 1 & Husky Oil NPR Operations, Inc. & $04 / 15 / 1980$ & 69.380167 & -152.175404 & Seabee & $100-280$ & K.J. Bird & - & Seabee near surface \\
\hline & Umiat No. 18 & Linc Energy Operations, Inc. & 4/29/2013 & 69.384851 & -152.119386 & Nanushuk & 230-1038 & \begin{tabular}{|c|} 
Well Completion or Recompletion \\
Report and Log (AOGCC)
\end{tabular} & - & Nanushuk near surface \\
\hline & Umiat No. $23 \mathrm{H}$ & Linc Energy Operations, Inc. & 3/20/2014 & 69.394405 & -152.196331 & - & - & - & well deviated to horizontal & Seabee near surface \\
\hline \multirow{5}{*}{$\begin{array}{l}\text { Gubik gas } \\
\text { field }\end{array}$} & Gubik Test No. 1* & U.S. Navy & $8 / 11 / 1951$ & 69.433907 & -151.475830 & \begin{tabular}{|c|} 
Schrader Bluff \\
(Barrow Trail \\
Member) \\
\end{tabular} & $67-295$ & Robinson (1958) & Pliocene to Recent: 12-67' (Robinson, 1958) & Barrow Trail near surface \\
\hline & Gubik Test No. 2 & U.S. Navy & 12/14/1951 & 69.424191 & -151.441676 & $\begin{array}{l}\text { Schrader Bluff } \\
\text { (Barrow Trail } \\
\text { Member) }\end{array}$ & $160-555$ & Robinson (1958) & $\begin{array}{l}\text { no core or cuttings from } 12-160^{\prime} \text { (Robinson, } \\
\text { 1958) }\end{array}$ & Barrow Trail near surface \\
\hline & Gubik Unit No. 1 & Colorado Oil and Gas & $11 / 12 / 1963$ & 69.428979 & -151.413502 & Schrader Bluff & $110-1136$ & K.J. Bird & Schrader Bluff members not picked & Barrow Trail near surface \\
\hline & Gubik No. 3 & Anadarko Petroleum Corporation & 4/14/2008 & 69.441454 & -151.442073 & Tuluvak & $1079-?$ & \begin{tabular}{|c|} 
Well Completion or Recompletion \\
Report and Log (AOGCC)
\end{tabular} & \begin{tabular}{|c|} 
Schrader Bluff not designated; top Seabee not \\
picked
\end{tabular} & Barrow Trail near surface \\
\hline & Gubik No. 4 & Anadarko Petroleum Corporation & 4/6/2009 & 69.429660 & -151.293870 & Tuluvak & $1461-2315$ & \begin{tabular}{|c|} 
Well Completion or Recompletion \\
Report and Log (AOGCC) \\
\end{tabular} & \begin{tabular}{|l} 
Schrader Bluff not designated; top Seabee not \\
picked
\end{tabular} & Sentinel Hill near surface \\
\hline \multirow{6}{*}{$\begin{array}{l}\text { East Umiat gas } \\
\text { field }\end{array}$} & $\begin{array}{l}\text { East Umiat Unit } \\
\text { No. } 1^{\star} \\
\end{array}$ & $\begin{array}{l}\text { Devon Energy Production Corpora- } \\
\text { tion LP }\end{array}$ & $3 / 28 / 1964$ & 69.344871 & -151.743740 & Tuluvak & $17-510$ & K.J. Bird & - & Tuluvak near surface \\
\hline & $\begin{array}{l}\text { East Umiat Unit } \\
\text { No. } 2 \\
\end{array}$ & McCulloch Oil Co & $5 / 21 / 1969$ & 69.359128 & -151.861659 & Tuluvak & $12-?$ & K.J. Bird & top Seabee not picked & Tuluvak near surface \\
\hline & \multirow{2}{*}{ Colville Unit No. 1} & \multirow{2}{*}{ McCulloch Oil Co } & \multirow{2}{*}{$3 / 11 / 1970$} & \multirow{2}{*}{69.337493} & \multirow{2}{*}{-151.912631} & $\begin{array}{l}\text { Prince Creek/ } \\
\text { Schrader Bluff } \\
\end{array}$ & 23-? & K.J. Bird & top Tuluvak not picked & - \\
\hline & & & & & & Seabee & $1640-2950$ & K.J. Bird & $\begin{array}{c}\text { uppermost formation pick that provides strati- } \\
\text { graphic context }\end{array}$ & Rogers Creek near surface \\
\hline & Colville Unit No. 2 & McCulloch Oil Co & $12 / 25 / 1971$ & 69.365277 & -151.833690 & Tuluvak & 23-? & K.J. Bird & top Seabee not picked & Tuluvak near surface \\
\hline & Chandler No. 1 & Anadarko Petroleum Corporation & $4 / 4 / 2009$ & 69.355210 & -151.633409 & Tuluvak & $120-1070$ & $\begin{array}{l}\text { Well Completion or Recompletion } \\
\text { Report and Log (AOGCC) }\end{array}$ & - & Rogers Creek near surface \\
\hline
\end{tabular}




\section{APPENDIX 2}

Table A2. Spreadsheet of fracture data employed in the Colville River corridor structural analysis of this study. Shear fractures are in bold; shear fractures that are uniquely constrained kinematically are in bold and underlined. See text for stereonet plots and discussion. Latitude and longitude reported in NAD27.

\begin{tabular}{|c|c|c|c|c|c|c|c|c|c|c|}
\hline & Locality & Map Unit & Station & Latitude & Longitude & Dip Azimuth & Dip & Rake & $\begin{array}{c}\text { Rake } \\
\text { Direction }\end{array}$ & Comment \\
\hline & \multirow[t]{60}{*}{ Colville incision } & \multirow{60}{*}{$\begin{array}{l}\text { Nanushuk } \\
\text { Formation }\end{array}$} & \multirow{60}{*}{$\begin{array}{l}11 \mathrm{BG} 304 \\
\text { 11BG305 } \\
\text { (traverse) }\end{array}$} & \multirow{60}{*}{\begin{tabular}{|l|}
69.272584 \\
69.273844 \\
\end{tabular}} & \multirow{60}{*}{$\begin{array}{l}152.585510 \\
152.610218\end{array}$} & 265 & 84 & & & \\
\hline$?$ & & & & & & 165 & 73 & & & \\
\hline 3 & & & & & & 84 & 89 & & & \\
\hline t & & & & & & 170 & 75 & & & \\
\hline 5 & & & & & & 159 & 54 & & & \\
\hline ; & & & & & & 175 & 50 & & & \\
\hline 7 & & & & & & 176 & 54 & & & \\
\hline 3 & & & & & & 183 & 55 & & & \\
\hline 9 & & & & & & 165 & 54 & & & \\
\hline 0 & & & & & & 78 & 83 & & & \\
\hline 1 & & & & & & 88 & 86 & & & \\
\hline 2 & & & & & & 87 & 90 & & & \\
\hline 3 & & & & & & 166 & 44 & & & \\
\hline 4 & & & & & & 163 & 69 & & & \\
\hline 5 & & & & & & 62 & 77 & & & \\
\hline 6 & & & & & & 174 & 63 & & & \\
\hline 7 & & & & & & 78 & 86 & & & \\
\hline 8 & & & & & & 171 & 64 & & & \\
\hline 9 & & & & & & 282 & 80 & & & \\
\hline 0 & & & & & & 274 & 84 & & & \\
\hline 1 & & & & & & 172 & 63 & & & \\
\hline 2 & & & & & & 176 & 57 & & & \\
\hline 3 & & & & & & 92 & 88 & & & \\
\hline 4 & & & & & & 110 & 54 & & & \\
\hline 5 & & & & & & 103 & 84 & 27 & SW & Reverse, left lateral \\
\hline 6 & & & & & & $\overline{101}$ & $\overline{84}$ & & & \\
\hline 7 & & & & & & 102 & 86 & & & \\
\hline 8 & & & & & & 272 & 88 & & & \\
\hline 9 & & & & & & $\underline{102}$ & $\underline{89}$ & 46 & SW & Reverse, left lateral \\
\hline 0 & & & & & & 98 & 89 & & & \\
\hline 1 & & & & & & 276 & 86 & & & \\
\hline 2 & & & & & & 155 & 49 & & & \\
\hline 3 & & & & & & $\underline{256}$ & $\underline{76}$ & 30 & $S$ & Reverse, right lateral \\
\hline 4 & & & & & & 257 & 82 & & & \\
\hline 5 & & & & & & 108 & 82 & & & \\
\hline 6 & & & & & & 69 & 89 & & & \\
\hline 7 & & & & & & 105 & 72 & 15 & SW & Reverse, left lateral \\
\hline 8 & & & & & & 81 & 74 & & & \\
\hline 9 & & & & & & $\underline{56}$ & $\underline{86}$ & 23 & SE & Normal, right lateral \\
\hline 0 & & & & & & $\overline{175}$ & $\overline{52}$ & & & \\
\hline 1 & & & & & & $\underline{246}$ & $\underline{78}$ & 29 & NW & Normal, right lateral \\
\hline 2 & & & & & & 279 & 82 & & & \\
\hline 3 & & & & & & 291 & 89 & & & \\
\hline 4 & & & & & & $\underline{250}$ & 77 & 34 & NW & Normal, right lateral \\
\hline 5 & & & & & & 171 & 46 & & & \\
\hline 6 & & & & & & 242 & 71 & & & \\
\hline 7 & & & & & & 173 & 66 & & & \\
\hline 8 & & & & & & 250 & 72 & & & \\
\hline 9 & & & & & & 174 & 61 & & & \\
\hline 0 & & & & & & 252 & 81 & & & \\
\hline 1 & & & & & & 178 & 60 & & & \\
\hline 2 & & & & & & 171 & 48 & & & \\
\hline 3 & & & & & & 166 & 57 & & & \\
\hline 4 & & & & & & 172 & 68 & & & \\
\hline 5 & & & & & & 187 & 60 & & & \\
\hline 6 & & & & & & 185 & 61 & & & \\
\hline 7 & & & & & & 170 & 55 & & & \\
\hline 8 & & & & & & 184 & 61 & & & \\
\hline 9 & & & & & & 175 & 57 & & & \\
\hline 0 & & & & & & 199 & 67 & & & \\
\hline
\end{tabular}


Table A2, continued. Spreadsheet of fracture data employed in the Colville River corridor structural analysis of this study. Shear fractures are in bold; shear fractures that are uniquely constrained kinematically are in bold and underlined. See text for stereonet plots and discussion. Latitude and longitude reported in NAD27.

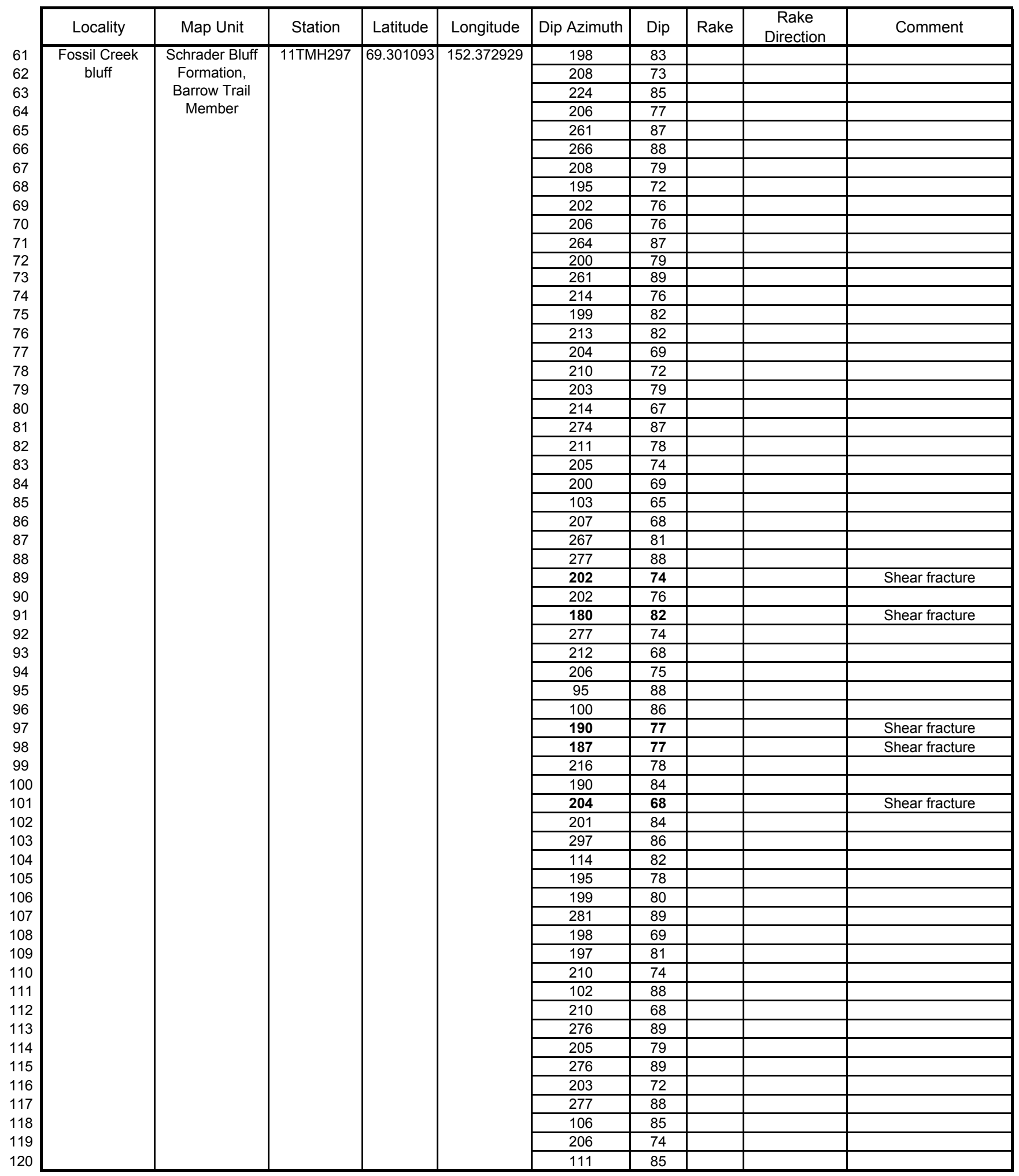


Table A2, continued. Spreadsheet of fracture data employed in the Colville River corridor structural analysis of this study. Shear fractures are in bold; shear fractures that are uniquely constrained kinematically are in bold and underlined. See text for stereonet plots and discussion. Latitude and longitude reported in NAD27.

\begin{tabular}{|c|c|c|c|c|c|c|c|c|c|}
\hline Locality & Map Unit & Station & Latitude & Longitude & Dip Azimuth & Dip & Rake & $\begin{array}{c}\text { Rake } \\
\text { Direction }\end{array}$ & Comment \\
\hline $\begin{array}{c}\text { Tattitgak Bluff, } \\
\text { west }\end{array}$ & $\begin{array}{l}\text { Schrader Bluff } \\
\text { Formation, } \\
\text { Barrow Trail } \\
\text { Member }\end{array}$ & 11BG261 & 69.333392 & 152.255174 & 295 & 85 & & & \\
\hline \multirow{13}{*}{$\begin{array}{l}\text { Tattitgak Bluff, } \\
\text { west }\end{array}$} & \multirow{13}{*}{$\begin{array}{l}\text { Schrader Bluff } \\
\text { Formation, } \\
\text { Barrow Trail } \\
\text { Member }\end{array}$} & \multirow[t]{13}{*}{ 11BG260 } & \multirow[t]{13}{*}{69.334172} & \multirow[t]{13}{*}{152.254704} & 134 & $\underline{12}$ & 22 & SW & Normal, right lateral \\
\hline & & & & & $\overline{185}$ & $\overline{42}$ & 86 & NW & Reverse, left lateral \\
\hline & & & & & $\overline{321}$ & $\overline{14}$ & 25 & $\mathrm{NE}$ & \\
\hline & & & & & 297 & 70 & & & \\
\hline & & & & & $\underline{52}$ & $\underline{66}$ & 30 & SE & Normal, right lateral \\
\hline & & & & & $\overline{29}$ & $\overline{33}$ & 57 & NW & \\
\hline & & & & & 107 & 88 & & & Left lateral \\
\hline & & & & & 326 & 16 & 57 & $\mathrm{NE}$ & Reverse, left lateral \\
\hline & & & & & 151 & 31 & 72 & SW & Reverse, left lateral \\
\hline & & & & & $\overline{198}$ & $\overline{27}$ & 87 & SE & Reverse, right lateral \\
\hline & & & & & $\underline{\underline{54}}$ & $\underline{44}$ & 47 & NW & Reverse, right lateral \\
\hline & & & & & 355 & $\overline{15}$ & 87 & SW & \\
\hline & & & & & 182 & 23 & 84 & SE & Reverse, right lateral \\
\hline \multirow{14}{*}{$\begin{array}{c}\text { Tattitgak Bluff, } \\
\text { west }\end{array}$} & \multirow{14}{*}{$\begin{array}{l}\text { Schrader Bluff } \\
\text { Formation, } \\
\text { Barrow Trail } \\
\text { Member }\end{array}$} & \multirow[t]{14}{*}{ 11BG259 } & \multirow[t]{14}{*}{69.335102} & \multirow[t]{14}{*}{152.253404} & $\overline{72}$ & $\overline{86}$ & & & \\
\hline & & & & & 280 & 84 & & & \\
\hline & & & & & $\underline{\underline{354}}$ & $\underline{21}$ & 86 & $\mathrm{~W}$ & Reverse, right lateral \\
\hline & & & & & $\overline{176}$ & $\overline{78}$ & & & \\
\hline & & & & & 108 & 88 & & & \\
\hline & & & & & 275 & 74 & & & \\
\hline & & & & & 1 & $\underline{34}$ & 65 & $\mathrm{~W}$ & Reverse, right lateral \\
\hline & & & & & 105 & $\overline{88}$ & & & \\
\hline & & & & & $\underline{335}$ & $\underline{23}$ & 75 & $\mathrm{NE}$ & Reverse, left lateral \\
\hline & & & & & 325 & $\overline{18}$ & 65 & $\mathrm{NE}$ & \\
\hline & & & & & 163 & 19 & 85 & $\mathrm{NE}$ & \\
\hline & & & & & 139 & 31 & 80 & SW & \\
\hline & & & & & 325 & 18 & & & Reverse \\
\hline & & & & & 198 & 18 & 84 & SE & Reverse, right lateral \\
\hline \multirow{23}{*}{$\begin{array}{c}\text { Tattitgak Bluff, } \\
\text { west }\end{array}$} & \multirow{23}{*}{$\begin{array}{l}\text { Schrader Bluff } \\
\text { Formation, } \\
\text { Barrow Trail } \\
\text { Member }\end{array}$} & 11TMH230 & 69.335812 & 152.252294 & 182 & 89 & & & \\
\hline & & & & & 266 & 76 & & & \\
\hline & & & & & 4 & 86 & & & \\
\hline & & & & & 24 & 77 & & & \\
\hline & & & & & 196 & 82 & & & \\
\hline & & & & & 27 & 77 & & & \\
\hline & & & & & 291 & 89 & & & \\
\hline & & & & & 111 & 84 & & & \\
\hline & & & & & 9 & 81 & & & \\
\hline & & & & & 4 & 79 & & & \\
\hline & & & & & 193 & 80 & & & \\
\hline & & & & & 7 & 84 & & & \\
\hline & & & & & 282 & 76 & & & \\
\hline & & & & & 102 & 89 & & & \\
\hline & & & & & 359 & 73 & & & \\
\hline & & & & & 3 & 86 & & & \\
\hline & & & & & 25 & 75 & & & \\
\hline & & & & & 1 & 82 & & & \\
\hline & & & & & 197 & 85 & & & \\
\hline & & & & & 359 & 85 & & & \\
\hline & & & & & 10 & 80 & & & \\
\hline & & & & & 1 & 80 & & & \\
\hline & & & & & 10 & 87 & & & \\
\hline Tattitgak Bluff, & Schrader Bluff & 11BG258 & 69.336052 & 152.251844 & 326 & 79 & & & \\
\hline west & Formation, & & & & 0 & 88 & & & \\
\hline & Barrow Trail & & & & 9 & 85 & & & \\
\hline & Member & & & & 332 & 84 & & & \\
\hline & & & & & 14 & 75 & & & \\
\hline & & & & & 2 & 72 & & & \\
\hline & & & & & 8 & 86 & & & \\
\hline & & & & & 5 & 89 & & & \\
\hline & & & & & 12 & 88 & & & \\
\hline & & & & & 356 & 81 & & & \\
\hline & & & & & 188 & 82 & & & \\
\hline & & & & & 193 & 88 & & & \\
\hline
\end{tabular}


Table A2, continued. Spreadsheet of fracture data employed in the Colville River corridor structural analysis of this study. Shear fractures are in bold; shear fractures that are uniquely constrained kinematically are in bold and underlined. See text for stereonet plots and discussion. Latitude and longitude reported in NAD27.

\begin{tabular}{|c|c|c|c|c|c|c|c|c|c|c|}
\hline & Locality & Map Unit & Station & Latitude & Longitude & Dip Azimuth & Dip & Rake & $\begin{array}{c}\text { Rake } \\
\text { Direction }\end{array}$ & Comment \\
\hline 184 & \multirow{7}{*}{$\begin{array}{c}\text { Tattitgak Bluff, } \\
\text { west }\end{array}$} & \multirow{7}{*}{$\begin{array}{l}\text { Schrader Bluff } \\
\text { Formation, } \\
\text { Barrow Trail } \\
\text { Member }\end{array}$} & \multirow{7}{*}{ 11BG257 } & \multirow{7}{*}{69.337042} & \multirow{7}{*}{152.249384} & 0 & 90 & & & \\
\hline 185 & & & & & & 15 & 79 & & & \\
\hline 186 & & & & & & 18 & 76 & & & \\
\hline 187 & & & & & & 357 & 84 & & & \\
\hline 188 & & & & & & 10 & 87 & & & \\
\hline 189 & & & & & & 17 & 69 & & & \\
\hline 190 & & & & & & 14 & 72 & & & \\
\hline 191 & \multirow{11}{*}{$\begin{array}{c}\text { Tattitgak Bluff, } \\
\text { west }\end{array}$} & \multirow{11}{*}{$\begin{array}{l}\text { Schrader Bluff } \\
\text { Formation, } \\
\text { Barrow Trail } \\
\text { Member }\end{array}$} & \multirow{11}{*}{ 11BG239 } & \multirow[t]{11}{*}{69.338072} & 152.243624 & 4 & 87 & & & Right lateral \\
\hline 192 & & & & & & 15 & 81 & & & \\
\hline 193 & & & & & & 13 & 87 & & & \\
\hline 194 & & & & & & 8 & 82 & & & \\
\hline 195 & & & & & & 10 & 86 & & & \\
\hline 196 & & & & & & 359 & 88 & & & \\
\hline 197 & & & & & & 30 & 79 & & & \\
\hline 198 & & & & & & 19 & 76 & & & \\
\hline 199 & & & & & & 12 & 84 & & & \\
\hline 200 & & & & & & 17 & 75 & & & \\
\hline 201 & & & & & & 14 & 74 & & & \\
\hline 202 & Tattitgak Bluff, & Schrader Bluff & 11DJM289 & 69.337022 & 152.173097 & 57 & 87 & & & \\
\hline 203 & east & Formation, & & & & 310 & 87 & & & \\
\hline 204 & & Barrow Trail & & & & 120 & 83 & & & \\
\hline 205 & & Member & & & & 118 & 85 & & & \\
\hline 206 & & & & & & 62 & 81 & & & \\
\hline 207 & & & & & & 57 & 81 & & & \\
\hline 208 & & & & & & 50 & 87 & & & \\
\hline 209 & & & & & & 322 & 87 & & & \\
\hline 210 & & & & & & 66 & 80 & & & \\
\hline 211 & & & & & & 240 & 81 & & & \\
\hline 212 & & & & & & 355 & 52 & & & \\
\hline 213 & & & & & & 0 & 48 & & & \\
\hline 214 & & & & & & 237 & 89 & & & \\
\hline 215 & & & & & & 3 & 55 & & & \\
\hline 216 & & & & & & 0 & 47 & & & \\
\hline 217 & & & & & & 352 & 53 & & & \\
\hline 218 & & & & & & 17 & 52 & & & \\
\hline 219 & & & & & & 65 & 82 & & & \\
\hline 220 & & & & & & 352 & 52 & & & \\
\hline 221 & & & & & & 351 & 51 & & & \\
\hline 222 & & & & & & 55 & 87 & & & \\
\hline 223 & & & & & & 60 & 85 & & & \\
\hline 224 & & & & & & 116 & 85 & & & \\
\hline 225 & & & & & & 302 & 85 & & & \\
\hline 226 & & & & & & 48 & 81 & & & \\
\hline 227 & & & & & & 50 & 75 & & & \\
\hline 228 & & & & & & 304 & 85 & & & \\
\hline 229 & & & & & & 17 & 73 & & & \\
\hline 230 & & & & & & 350 & 40 & & & \\
\hline 231 & & & & & & 350 & 42 & & & \\
\hline 232 & & & & & & 45 & 82 & & & \\
\hline 233 & & & & & & 58 & 86 & & & \\
\hline 234 & & & & & & 352 & 54 & & & \\
\hline 235 & & & & & & 326 & 86 & & & \\
\hline 236 & & & & & & 60 & 82 & & & \\
\hline 237 & & & & & & 322 & 87 & & & \\
\hline 238 & & & & & & 54 & 70 & & & \\
\hline 239 & & & & & & 45 & 83 & & & \\
\hline 240 & & & & & & 320 & 87 & & & \\
\hline 241 & & & & & & 48 & 81 & & & \\
\hline 242 & & & & & & 47 & 89 & & & \\
\hline 243 & & & & & & 334 & 79 & & & \\
\hline 244 & & & & & & 48 & 85 & & & \\
\hline 245 & & & & & & 354 & 50 & & & \\
\hline 246 & & & & & & 9 & 54 & & & \\
\hline 247 & & & & & & 1 & 47 & & & \\
\hline 248 & & & & & & 319 & 70 & & & \\
\hline 249 & & & & & & 348 & 55 & & & \\
\hline 250 & & & & & & 353 & 43 & & & \\
\hline 251 & & & & & & 50 & 87 & & & \\
\hline
\end{tabular}


Table A2, continued. Spreadsheet of fracture data employed in the Colville River corridor structural analysis of this study. Shear fractures are in bold; shear fractures that are uniquely constrained kinematically are in bold and underlined. See text for stereonet plots and discussion. Latitude and longitude reported in NAD27.

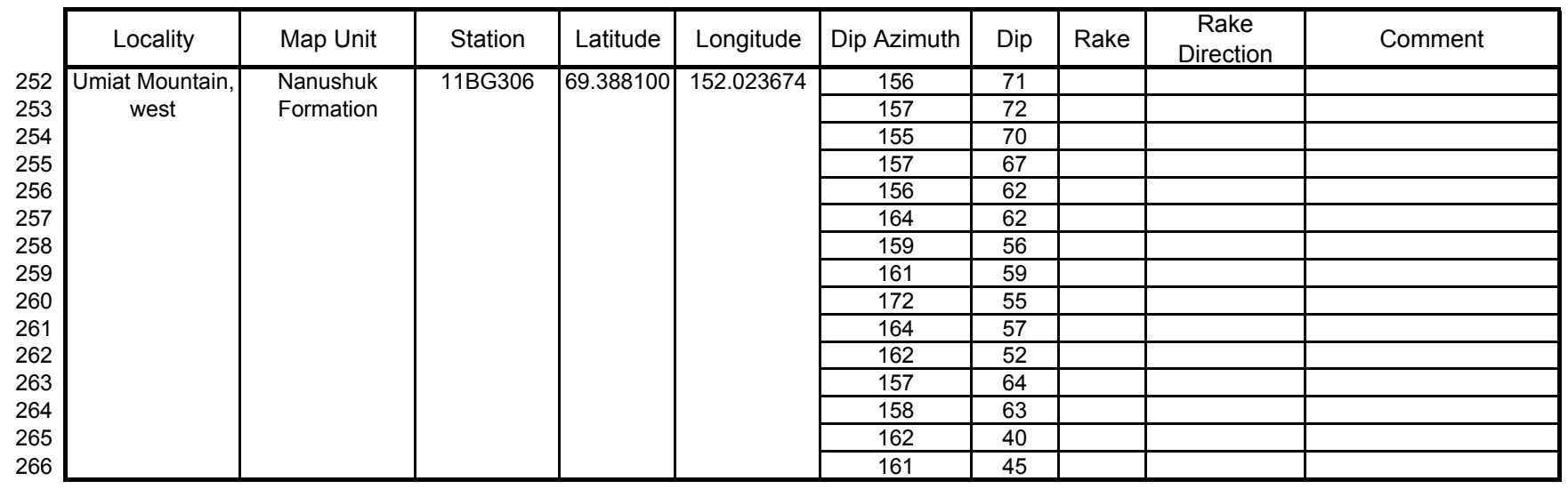




\section{Report of Investigation 2018-6}

Table A2, continued. Spreadsheet of fracture data employed in the Colville River corridor structural analysis of this study. Shear fractures are in bold; shear fractures that are uniquely constrained kinematically are in bold and underlined. See text for stereonet plots and discussion. Latitude and longitude reported in NAD27.

\begin{tabular}{|c|c|c|c|c|c|c|c|c|c|c|}
\hline & Locality & Map Unit & Station & Latitude & Longitude & Dip Azimuth & Dip & Rake & $\begin{array}{c}\text { Rake } \\
\text { Direction }\end{array}$ & Comment \\
\hline 267 & \multirow{60}{*}{\begin{tabular}{|c|} 
Umiat Mountain, \\
east
\end{tabular}} & \multirow{60}{*}{$\begin{array}{c}\text { Seabee } \\
\text { Formation }\end{array}$} & \multirow{60}{*}{ 11BG308 } & \multirow{60}{*}{69.387980} & \multirow[t]{60}{*}{151.985485} & 251 & 78 & & & \\
\hline 268 & & & & & & 182 & 88 & & & \\
\hline 269 & & & & & & 262 & 88 & & & \\
\hline 270 & & & & & & 254 & 64 & & & \\
\hline 271 & & & & & & 182 & 88 & & & \\
\hline 272 & & & & & & 245 & 66 & & & \\
\hline 273 & & & & & & 165 & 82 & & & \\
\hline 274 & & & & & & 254 & 82 & & & \\
\hline 275 & & & & & & 264 & 65 & & & \\
\hline 276 & & & & & & 248 & 82 & & & \\
\hline 277 & & & & & & 170 & 80 & & & \\
\hline 278 & & & & & & 240 & 75 & & & \\
\hline 279 & & & & & & 236 & 80 & & & \\
\hline 280 & & & & & & 163 & 73 & & & \\
\hline 281 & & & & & & 240 & 79 & & & \\
\hline 282 & & & & & & 140 & 87 & & & \\
\hline 283 & & & & & & 138 & 89 & & & \\
\hline 284 & & & & & & 246 & 75 & & & \\
\hline 285 & & & & & & 235 & 82 & & & \\
\hline 286 & & & & & & 344 & 82 & & & \\
\hline 287 & & & & & & 330 & 85 & & & \\
\hline 288 & & & & & & 233 & 75 & & & \\
\hline 289 & & & & & & 132 & 78 & & & \\
\hline 290 & & & & & & 330 & 80 & & & \\
\hline 291 & & & & & & 241 & 74 & & & \\
\hline 292 & & & & & & 240 & 76 & & & \\
\hline 293 & & & & & & 237 & 77 & & & \\
\hline 294 & & & & & & 232 & 76 & & & \\
\hline 295 & & & & & & 237 & 76 & & & \\
\hline 296 & & & & & & 241 & 81 & & & \\
\hline 297 & & & & & & 235 & 78 & & & \\
\hline 298 & & & & & & 237 & 80 & & & \\
\hline 299 & & & & & & 236 & 78 & & & \\
\hline 300 & & & & & & 247 & 73 & & & \\
\hline 301 & & & & & & 249 & 79 & & & \\
\hline 302 & & & & & & 194 & 79 & & & \\
\hline 303 & & & & & & 179 & 81 & & & \\
\hline 304 & & & & & & 165 & 83 & & & \\
\hline 305 & & & & & & 165 & 82 & & & \\
\hline 306 & & & & & & 345 & 83 & & & \\
\hline 307 & & & & & & 135 & 80 & & & \\
\hline 308 & & & & & & 232 & 71 & & & \\
\hline 309 & & & & & & 242 & 79 & & & \\
\hline 310 & & & & & & 243 & 83 & & & \\
\hline 311 & & & & & & 158 & 80 & & & \\
\hline 312 & & & & & & 240 & 79 & & & \\
\hline 313 & & & & & & 157 & 84 & & & \\
\hline 314 & & & & & & 155 & 73 & & & \\
\hline 315 & & & & & & 156 & 85 & & & \\
\hline 316 & & & & & & 156 & 81 & & & \\
\hline 317 & & & & & & 242 & 71 & & & \\
\hline 318 & & & & & & 162 & 86 & & & \\
\hline 319 & & & & & & 158 & 84 & & & \\
\hline 320 & & & & & & 142 & 81 & & & \\
\hline 321 & & & & & & 164 & 70 & & & \\
\hline 322 & & & & & & 239 & 83 & & & \\
\hline 323 & & & & & & 235 & 77 & & & \\
\hline 324 & & & & & & 241 & 72 & & & \\
\hline 325 & & & & & & 243 & 57 & & & \\
\hline 326 & & & & & & 240 & 87 & & & \\
\hline
\end{tabular}


Table A2, continued. Spreadsheet of fracture data employed in the Colville River corridor structural analysis of this study. Shear fractures are in bold; shear fractures that are uniquely constrained kinematically are in bold and underlined. See text for stereonet plots and discussion. Latitude and longitude reported in NAD27.

\begin{tabular}{|c|c|c|c|c|c|c|c|c|c|c|}
\hline & Locality & Map Unit & Station & Latitude & Longitude & Dip Azimuth & Dip & Rake & $\begin{array}{c}\text { Rake } \\
\text { Direction }\end{array}$ & Comment \\
\hline 327 & \multirow{15}{*}{\begin{tabular}{|c|}
$\begin{array}{c}\text { Umiat Mountain, } \\
\text { east }\end{array}$ \\
\end{tabular}} & \multirow{15}{*}{$\begin{array}{l}\text { Tuluvak } \\
\text { Formation }\end{array}$} & \multirow[t]{15}{*}{ 11DJM291 } & \multirow[t]{15}{*}{69.385780} & \multirow[t]{15}{*}{151.977516} & 242 & 72 & & & Left lateral \\
\hline 328 & & & & & & 242 & 85 & & & \\
\hline 329 & & & & & & 169 & 77 & & & \\
\hline 330 & & & & & & 245 & 73 & & & Left lateral \\
\hline 331 & & & & & & 178 & 89 & & & \\
\hline 332 & & & & & & 265 & 78 & & & \\
\hline 333 & & & & & & 303 & 77 & & & Left lateral \\
\hline 334 & & & & & & 180 & 88 & & & \\
\hline 335 & & & & & & 242 & 81 & & & \\
\hline 336 & & & & & & 68 & 87 & & & \\
\hline 337 & & & & & & 183 & 77 & & & \\
\hline 338 & & & & & & 245 & 89 & & & \\
\hline 339 & & & & & & 26 & 87 & & & \\
\hline 340 & & & & & & 249 & 87 & & & \\
\hline 341 & & & & & & 302 & 72 & & & \\
\hline 342 & \multirow{18}{*}{$\begin{array}{c}\begin{array}{c}\text { Umiat Mountain, } \\
\text { east }\end{array} \\
\end{array}$} & \multirow{18}{*}{$\begin{array}{l}\text { Tuluvak } \\
\text { Formation }\end{array}$} & \multirow{18}{*}{ 11TMH299 } & \multirow[t]{18}{*}{69.385530} & \multirow[t]{18}{*}{151.976836} & 243 & 89 & & & \\
\hline 343 & & & & & & 240 & 89 & & & \\
\hline 344 & & & & & & 70 & 84 & & & \\
\hline 345 & & & & & & 245 & 86 & & & \\
\hline 346 & & & & & & 71 & 85 & & & \\
\hline 347 & & & & & & 296 & 82 & & & \\
\hline 348 & & & & & & 297 & 75 & & & \\
\hline 349 & & & & & & 242 & 82 & & & \\
\hline 350 & & & & & & 294 & 70 & & & \\
\hline 351 & & & & & & 302 & 89 & & & \\
\hline 352 & & & & & & 238 & 87 & & & \\
\hline 353 & & & & & & 15 & 86 & & & \\
\hline 354 & & & & & & 17 & 83 & & & \\
\hline 355 & & & & & & 198 & 80 & & & \\
\hline 356 & & & & & & 241 & 74 & & & \\
\hline 357 & & & & & & $\underline{249}$ & $\underline{78}$ & 1 & SE & Reverse, right lateral \\
\hline 358 & & & & & & $\underline{288}$ & $\underline{76}$ & 2 & SW & Normal, left lateral \\
\hline 359 & & & & & & 303 & 83 & 0 & $\mathrm{NE}$ & Right lateral \\
\hline 360 & \multirow{24}{*}{$\begin{array}{c}\text { Umiat Mountain, } \\
\text { east }\end{array}$} & \multirow{24}{*}{$\begin{array}{l}\text { Tuluvak } \\
\text { Formation }\end{array}$} & \multirow{24}{*}{ 11BG309 } & \multirow{24}{*}{69.385480} & \multirow{24}{*}{151.975706} & 244 & 90 & & & \\
\hline 361 & & & & & & 30 & 80 & & & \\
\hline 362 & & & & & & 298 & 77 & & & \\
\hline 363 & & & & & & 251 & 85 & & & \\
\hline 364 & & & & & & 298 & 80 & & & \\
\hline 365 & & & & & & 294 & 78 & & & \\
\hline 366 & & & & & & 242 & 90 & & & \\
\hline 367 & & & & & & 248 & 88 & & & \\
\hline 368 & & & & & & 250 & 84 & & & \\
\hline 369 & & & & & & 252 & 85 & & & \\
\hline 370 & & & & & & 179 & 89 & & & \\
\hline 371 & & & & & & $\underline{240}$ & $\underline{85}$ & 5 & NW & Normal, right lateral \\
\hline 372 & & & & & & 226 & 76 & & & \\
\hline 373 & & & & & & 197 & 88 & & & \\
\hline 374 & & & & & & 180 & 89 & & & \\
\hline 375 & & & & & & 177 & 89 & & & \\
\hline 376 & & & & & & 62 & 85 & & & \\
\hline 377 & & & & & & 139 & 77 & & & \\
\hline 378 & & & & & & 240 & 90 & & & \\
\hline 379 & & & & & & 235 & 82 & & & \\
\hline 380 & & & & & & 243 & 76 & & & \\
\hline 381 & & & & & & 175 & 88 & & & \\
\hline 382 & & & & & & 191 & 90 & & & \\
\hline 383 & & & & & & 190 & 74 & & & \\
\hline
\end{tabular}




\section{Report of Investigation 2018-6}

Table A2, continued. Spreadsheet of fracture data employed in the Colville River corridor structural analysis of this study. Shear fractures are in bold; shear fractures that are uniquely constrained kinematically are in bold and underlined. See text for stereonet plots and discussion. Latitude and longitude reported in NAD27.

\begin{tabular}{|c|c|c|c|c|c|c|c|c|c|}
\hline Locality & Map Unit & Station & Latitude & Longitude & Dip Azimuth & Dip & Rake & $\begin{array}{c}\text { Rake } \\
\text { Direction }\end{array}$ & Comment \\
\hline \multirow{50}{*}{$\begin{array}{c}\begin{array}{c}\text { Shivugak Bluff, } \\
\text { west }\end{array} \\
\text {, }\end{array}$} & \multirow{50}{*}{$\begin{array}{c}\text { Schrader Bluff } \\
\text { Formation, } \\
\text { Barrow Trail } \\
\text { Member }\end{array}$} & \multirow[t]{50}{*}{ 11DJM290 } & \multirow[t]{50}{*}{69.406549} & \multirow{50}{*}{151.845481} & 195 & 81 & & & \\
\hline & & & & & 117 & 88 & & & \\
\hline & & & & & 10 & 89 & & & \\
\hline & & & & & 130 & 73 & & & \\
\hline & & & & & 200 & 75 & & & \\
\hline & & & & & 225 & 78 & & & \\
\hline & & & & & 170 & 68 & & & \\
\hline & & & & & 197 & 67 & & & \\
\hline & & & & & 105 & 90 & & & \\
\hline & & & & & 183 & 73 & & & \\
\hline & & & & & 285 & 78 & & & \\
\hline & & & & & 123 & 77 & & & \\
\hline & & & & & 175 & 82 & & & \\
\hline & & & & & 115 & 85 & & & \\
\hline & & & & & 193 & 45 & & & \\
\hline & & & & & 190 & 42 & & & \\
\hline & & & & & 178 & 42 & & & \\
\hline & & & & & 188 & 85 & & & \\
\hline & & & & & 155 & 45 & & & \\
\hline & & & & & 126 & 68 & & & \\
\hline & & & & & 158 & 40 & & & \\
\hline & & & & & 193 & 89 & & & \\
\hline & & & & & 192 & 89 & & & \\
\hline & & & & & 284 & 87 & & & \\
\hline & & & & & 122 & 71 & & & \\
\hline & & & & & 15 & 85 & & & \\
\hline & & & & & 320 & 89 & & & \\
\hline & & & & & 21 & 89 & & & \\
\hline & & & & & 12 & 89 & & & \\
\hline & & & & & 15 & 85 & & & \\
\hline & & & & & 122 & 80 & & & \\
\hline & & & & & 355 & 77 & & & \\
\hline & & & & & 290 & 82 & & & \\
\hline & & & & & 132 & 45 & & & \\
\hline & & & & & 175 & 80 & & & \\
\hline & & & & & 10 & 80 & & & \\
\hline & & & & & 168 & 59 & & & \\
\hline & & & & & 103 & 86 & & & \\
\hline & & & & & 91 & 81 & & & \\
\hline & & & & & 274 & 82 & & & \\
\hline & & & & & 7 & 81 & & & \\
\hline & & & & & 12 & 60 & & & \\
\hline & & & & & 193 & 77 & & & \\
\hline & & & & & 103 & 58 & & & \\
\hline & & & & & 190 & 85 & & & \\
\hline & & & & & 184 & 60 & & & \\
\hline & & & & & 140 & 71 & & & \\
\hline & & & & & 190 & 70 & & & \\
\hline & & & & & 69 & 72 & & & \\
\hline & & & & & 109 & 88 & & & \\
\hline
\end{tabular}


Table A2, continued. Spreadsheet of fracture data employed in the Colville River corridor structural analysis of this study. Shear fractures are in bold; shear fractures that are uniquely constrained kinematically are in bold and underlined. See text for stereonet plots and discussion. Latitude and longitude reported in NAD27.

\begin{tabular}{|c|c|c|c|c|c|c|c|c|c|c|}
\hline & Locality & Map Unit & Station & Latitude & Longitude & Dip Azimuth & Dip & Rake & $\begin{array}{c}\text { Rake } \\
\text { Direction }\end{array}$ & Comment \\
\hline 434 & \multirow{60}{*}{$\begin{array}{c}\text { Shivugak Bluff, } \\
\text { east }\end{array}$} & \multirow{60}{*}{$\begin{array}{l}\text { Prince Creek } \\
\text { Formation }\end{array}$} & \multirow{60}{*}{ 11TMH298 } & \multirow{60}{*}{69.428899} & \multirow[t]{60}{*}{151.607012} & 158 & 83 & & & \\
\hline 435 & & & & & & 158 & 85 & & & \\
\hline 436 & & & & & & 120 & 89 & & & \\
\hline 437 & & & & & & 356 & 88 & & & \\
\hline 438 & & & & & & 106 & 79 & & & \\
\hline 439 & & & & & & 105 & 89 & & & \\
\hline 440 & & & & & & 161 & 79 & & & \\
\hline 441 & & & & & & 106 & 71 & & & \\
\hline 442 & & & & & & 191 & 85 & & & \\
\hline 443 & & & & & & 50 & 87 & & & \\
\hline 444 & & & & & & 112 & 89 & & & \\
\hline 445 & & & & & & 228 & 89 & & & \\
\hline 446 & & & & & & 71 & 85 & & & \\
\hline 447 & & & & & & 125 & 84 & & & \\
\hline 448 & & & & & & 252 & 86 & & & \\
\hline 449 & & & & & & 259 & 88 & & & \\
\hline 450 & & & & & & 218 & 61 & & & \\
\hline 451 & & & & & & 209 & 77 & & & \\
\hline 452 & & & & & & 118 & 79 & & & \\
\hline 453 & & & & & & 251 & 82 & & & \\
\hline 454 & & & & & & 122 & 78 & & & \\
\hline 455 & & & & & & 126 & 86 & & & \\
\hline 456 & & & & & & 55 & 76 & & & \\
\hline 457 & & & & & & 144 & 88 & & & \\
\hline 458 & & & & & & 246 & 88 & & & \\
\hline 459 & & & & & & 146 & 89 & & & \\
\hline 460 & & & & & & 255 & 87 & & & \\
\hline 461 & & & & & & 6 & 82 & & & \\
\hline 462 & & & & & & 71 & 81 & & & \\
\hline 463 & & & & & & 104 & 52 & & & \\
\hline 464 & & & & & & 30 & 82 & & & \\
\hline 465 & & & & & & 197 & 80 & & & \\
\hline 466 & & & & & & 230 & 78 & & & \\
\hline 467 & & & & & & 297 & 87 & & & \\
\hline 468 & & & & & & 113 & 77 & & & \\
\hline 469 & & & & & & 163 & 74 & & & \\
\hline 470 & & & & & & 291 & 87 & & & \\
\hline 471 & & & & & & 80 & 87 & & & \\
\hline 472 & & & & & & 72 & 85 & & & \\
\hline 473 & & & & & & 118 & 86 & & & \\
\hline 474 & & & & & & 334 & 87 & & & \\
\hline 475 & & & & & & 220 & 85 & & & \\
\hline 476 & & & & & & 117 & 79 & & & \\
\hline 477 & & & & & & 213 & 88 & & & \\
\hline 478 & & & & & & 36 & 75 & & & \\
\hline 479 & & & & & & 56 & 76 & & & \\
\hline 480 & & & & & & 114 & 72 & & & \\
\hline 481 & & & & & & 295 & 89 & & & \\
\hline 482 & & & & & & 118 & 70 & & & \\
\hline 483 & & & & & & 67 & 85 & & & \\
\hline 484 & & & & & & 107 & 83 & & & \\
\hline 485 & & & & & & 258 & 85 & & & \\
\hline 486 & & & & & & 14 & 82 & & & \\
\hline 487 & & & & & & 128 & 83 & & & \\
\hline 488 & & & & & & 66 & 85 & & & \\
\hline 489 & & & & & & 112 & 85 & & & \\
\hline 490 & & & & & & 176 & 85 & & & \\
\hline 491 & & & & & & 114 & 82 & & & \\
\hline 492 & & & & & & 246 & 82 & & & \\
\hline 493 & & & & & & 73 & 88 & & & \\
\hline
\end{tabular}

